\title{
Formal proposal for the Bathonian GSSP (Middle Jurassic) in the Ravin du Bès Section (Bas-Auran, SE France)
}

\author{
Sixto R. Fernández-López ${ }^{1, *}$, Giulio Pavia ${ }^{2}$, Elisabetra Erba ${ }^{3}$, Myetr Guiomar $^{4}$, Maria \\ H. Henriques ${ }^{5}$, Roberto Lanza $^{2}$, Charles Mangold $^{6}$, Davide Olivero $^{6} \&$ Daniele Tiraboschi $^{3}$
}

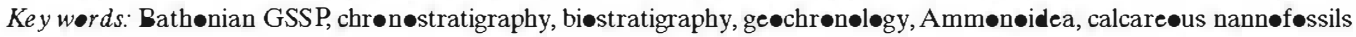

\begin{abstract}
ABSTRACI

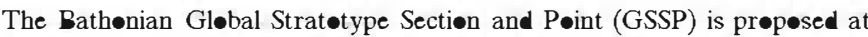
the base of limestone bed RB071 (bed 23 in Sturani 1967) in the Ravin du Bès Section (43॰ 57' 38" N, 6•18' 55" E), Bas-Auran area, "Alpes de Haute Prøvence" French department. The Ravin du BèsSectiøn, as førmal candidate

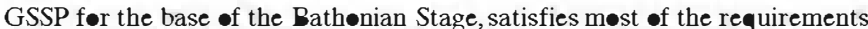
recommended by the Internatiønal Cømmissiøn $\bullet$ Stratigraphy: 1) The ex-

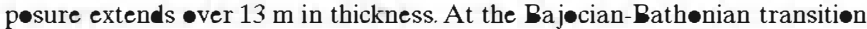

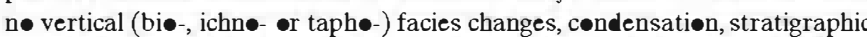
gaps $\bullet$ hiatuses have been recørded. Structural cœmplexity, synsedimentary

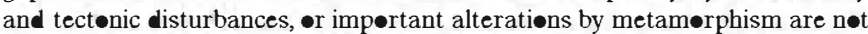
relevant constraints. 2) There is a well-preserved, abundant and diverse føssil record acress the bøundary interval, with key markers (ammønites and
\end{abstract}

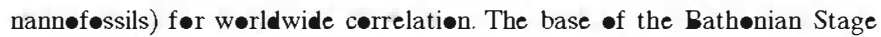

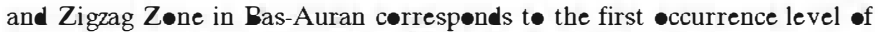
Genølkites cenvergens BUCKMAN, which coincides with the first eccurrence of

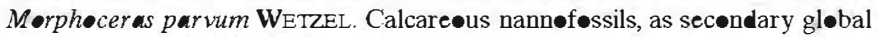
marker, are present in all beds and allow characterizing the Bajecian-Bathnian transition.3) Regiønal analyses of sequence stratigraphy and manganese chemestratigraphy are available. Spectral gamma-ray data correberate an Early Bathønian deepening half-cycle of secønder. 4) The criteria of accessibility, cønservation and protection are assured by the "Réserve Naturelle

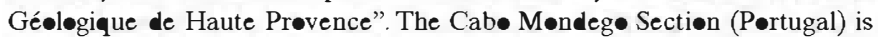
suggested as the Bathønian auxiliary sectiøn and pøint (ASSP) within this GSSP prøpesal.

\section{Introduction}

The present paper corresponds to part of the scientific dossier recently prepared by several specialists and sent to all members of the Bathonian Working Group (International Subcommission on Jurassic Stratigraphy, November 2007), in order to achieve the formal ballot on the selection and proposal of the Global Stratotype Section and Point (hereafter GSSP) for the Bathonian Stage (Fernández-López et al.2007b).The following persons are members of the Bathonian Working Group: Alméras Y. (France), Bardhan S. (India), Bodergat A.M. (France), Callomon J.H. (UK), Cresta S. (Italy), Dietl G. (Germany), Dietze V. (Germany), Enay R. (France), Fernández-López S.R. (Spain), Galácz A. (Hungary), Hall R.L. (Canada), Henriques M.H. (Portugal), Hillebrandt A. von (Germany), Lanza R. (Italy), Mangold C. (France), Matyja B. (Poland), Meléndez G. (Spain), Mitta, V. (Russia), Mönnig, E. (Germany), Morton N. (France),
Page K. (UK), Pandey D.K. (India), Pavia G. (Italy), Poulsen N. (Denmark), Poulton T.P. (Canada), Riccardi A.C. (Argentina), Rogov M.A. (Russia), Sandoval J. (Spain), Schlögl J. (Slovak Republic), Schweigert G. (Germany), Seyed-Emami K. (Iran), Wierzbowski A. (Poland), Yin J.-R. (China). The results of the vote (December 2007) has been as follows: Total BtWG members $=33$, YES votes $=31(93.4 \%)$, NO votes $=1$ (3.03), ABSTAIN $=1(3.03 \%)$, NO RESPONSE $=0$.

The Bathonian Working Group (BtWG) was established in 1984, during the $1^{\text {st }}$ International Symposium on Jurassic Stratigraphy in Erlangen, in order to improve the geologic data relative to the Bajocian/Bathonian boundary. The Bas-Auran section was first proposed as stratotype in a presentation to the Luxembourg II (1967) Colloquium by Torrens, but not published until 1974 (Morton 1974; Torrens 1974a, b, 1987, 2002). This section was formally proposed as a candidate for the basal boundary stratotype of the Bathonian Stage by Innocenti et

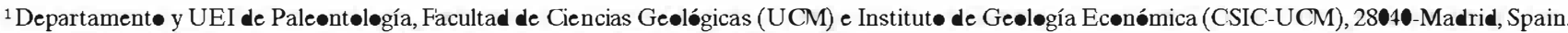

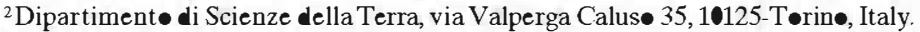

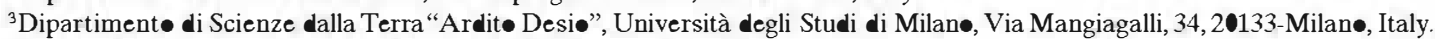

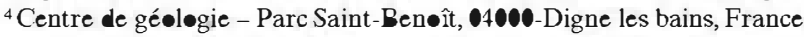

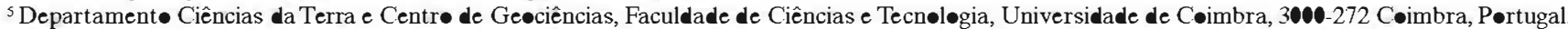

${ }^{6}$ Université Claude Bernard, Lyøn-1, UFR des Sciences de la Terre et CNRS, UMR 5125, 27-43, bel du 11-Nøvembre-1918, 69622-Villeurbanne cedex, France

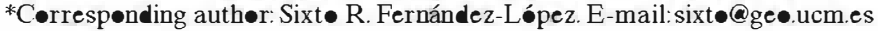


al. (1990) during the $2^{\text {nd }}$ International Symposium on Jurassic Stratigraphy in Lisbon (1987). Over the following 20 years, several meetings have been organized by the Bathonian Working Group in Digne, La Palud, Budapest, Lyon and Torino. In the Bas-Auran area, the sections of Ravin du Bès, Ravin d'Auran and Ravin des Robines have been remeasured and recollected for taphonomic, sedimentologic and palaeoichnological analyses during 2006 and 2007. Reports from the Bathonian Working Group have been published by Mangold (from 1984 to 1999) and Fernández-López (from 2003 to 2007a) as mentioned in Fernández-López (2008). Over all the many years, no other candidate sections (besides Cabo Mondego) were judged worthy of consideration.

This dossier summarizes relevant results published by specialists, as well as comments and responses of the BtWG ballot 2007, in order to achieve the formal ballot on the proposal of the GSSP for the Bathonian Stage within the International Subcommission on Jurassic Stratigraphy.

\section{Definition of the base of the Bathonian Stage (S.R. Fernández-López)}

The Bathonian is the third of the four stages of the Middle Jurassic Series, above the Bajocian and below the Callovian. The name was introduced by d'Halloy (1843) and used as a stage by d'Orbigny (1850, pp. 607-608; 1852, pp. 491-492), derived from the "Bath Oolite", in the vicinity of the city of Bath (SW England). Zigzagiceras zigzag (D'ORBIGNY 1846, p. 390, pl. 129, figs. 9-10; Arkell 1958, p. 177, text-fig. 60, 1-3) and Gonolkites convergens BUCKMAN (1925, pl. 546 A-B; Arkell 1956, pl. 18, fig. 8; pl. 19, figs.1-2) are the index species, respectively, of the Bathonian basal zone and subzone. The Zigzag Zone was distinguished from the underlying Parkinsoni Zone by Oppel (1857, p. 579, 1862), and later assigned to the "Bath-Gruppe" (Oppel 1865, p. 309) in a discussion of the section at "Montagne de Crussol" in the Ardèche (France). The Convergens Subzone was mentioned by Maubeuge (1950, p. 4), based on the "Convergens horizon" that was used in letters by Arkell (1951-59, p.10; 1956, p. 62). The Bajocian/Bathonian boundary established between the Parkinsoni and Zigzag zones was recommended at the two congresses denominated "Colloque du Jurassique" held in Luxembourg in 1962 (Rioult 1964; Torrens 1965) and 1967 (Torrens 1974a, b). The localities of Bath (England) and the "Montagne de Crussol" (France), however, have been considered quite unsuitable for a typological definition of the Bathonian Stage, because they are condensed sections with discontinuous and lenticular beds (Torrens 1974a, b, 2002; Page 1996b). After the publication of Sturani (1967), the base of bed 23 of the Bas-Auran section, in which Gonolkites convergens BUCKMAN, Parkinsonia pachypleura BUCKMAN and Morphoceras parvum WETZEL first appear, was designated as the type by which to define the base for the Convergens Subzone of the Zigzag Zone and the base of the Bathonian Stage by several authors (Morton 1974; Torrens 1974a, b, 1987; Harland et al. 1982). Later, there was general agreement among
Bathonian specialists that the Bathonian Stage should start with the Standard Zigzag Zone, whose base is defined by the Convergens Subzone (Horizon 1 of Mangold 1984) followed by the Macrescens Subzone (Sturani 1967). The Parvum Subzone has been proposed by Mangold (1990) to denote the first Bathonian subzone of the Zigzag Zone in the Sub-Mediterranean Province, equivalent to the Convergens Subzone of the Northwest European Province and below the Macrescens Subzone. Analogously, due to palaeobiogeographical changes, the Dimorphitiformis Subzone has been proposed by Sandoval (1983) as the basal Bathonian subzone of the Zigzag Zone in the Mediterranean Province. Therefore, the position of the Bathonian basal boundary became justified by the base of the Northwest European Convergens Subzone of the Zigzag Zone remarkably well recorded in the Bas-Auran area, a place where both Convergens and Parvum subzones can be recognized and denote the rock bodies of the same stratigraphic interval (Fernández-López et al. 2007a; Pavia et al. 2008).

\section{The Ravin du Bès Section (Bas-Auran area)}

The Bas-Auran sections are located in southeastern France, in the French department "Alpes de Haute Provence", in the Chaudon-Norante commune, around $25 \mathrm{~km}$ to the SouthSoutheast of Digne-les-Bains (Fig. 1). Three sections have been selected in two ravines (Fig. 2). The first, the Ravin du Bès Section (RB), is located near the farm l'Amata (coordinates: $43^{\circ} 57^{\prime} 38^{\prime \prime} \mathrm{N}, 6^{\circ} 18^{\prime} 55^{\prime \prime} \mathrm{E}$, altitude $730 \mathrm{~m}$ ). The second, the Ravin d'Auran Section (RA), is located in front of the farm BasAuran (coordinates: $43^{\circ} 57^{\prime} 29^{\prime \prime} \mathrm{N}, 6^{\circ} 19^{\prime} 00^{\prime \prime} \mathrm{E}$, altitude $790 \mathrm{~m}$ ). The third one, the Ravin des Robines Section (RR), is just 400

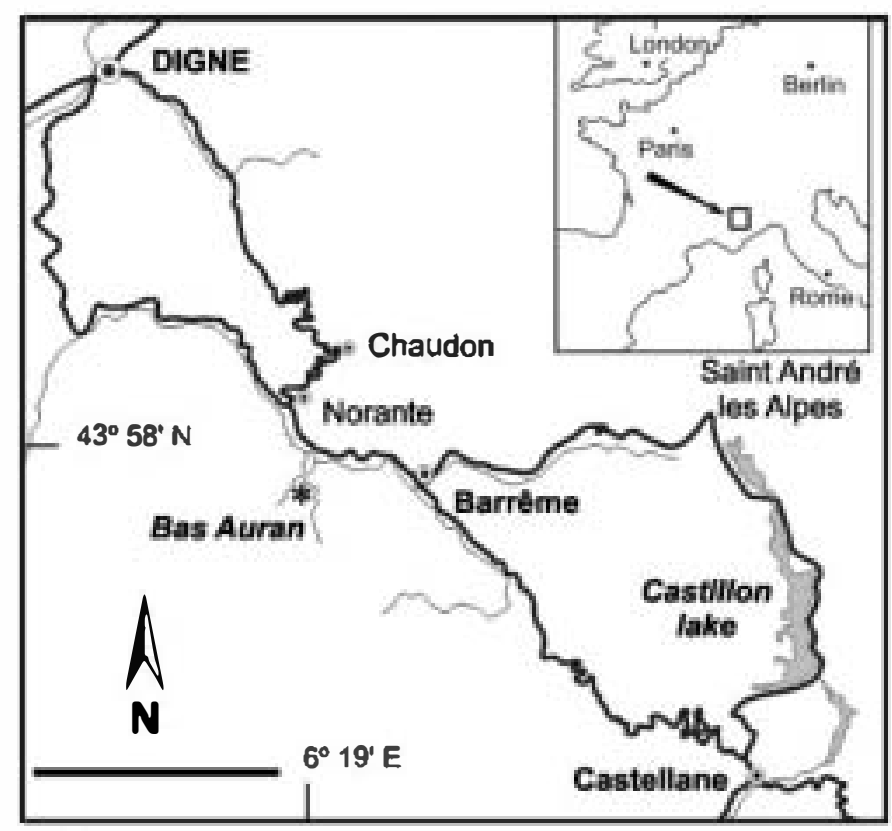

Fig. 1. Geøgraphical setting of the Bas-Auran area (France). Scale bar is $10 \mathrm{~km}$. 


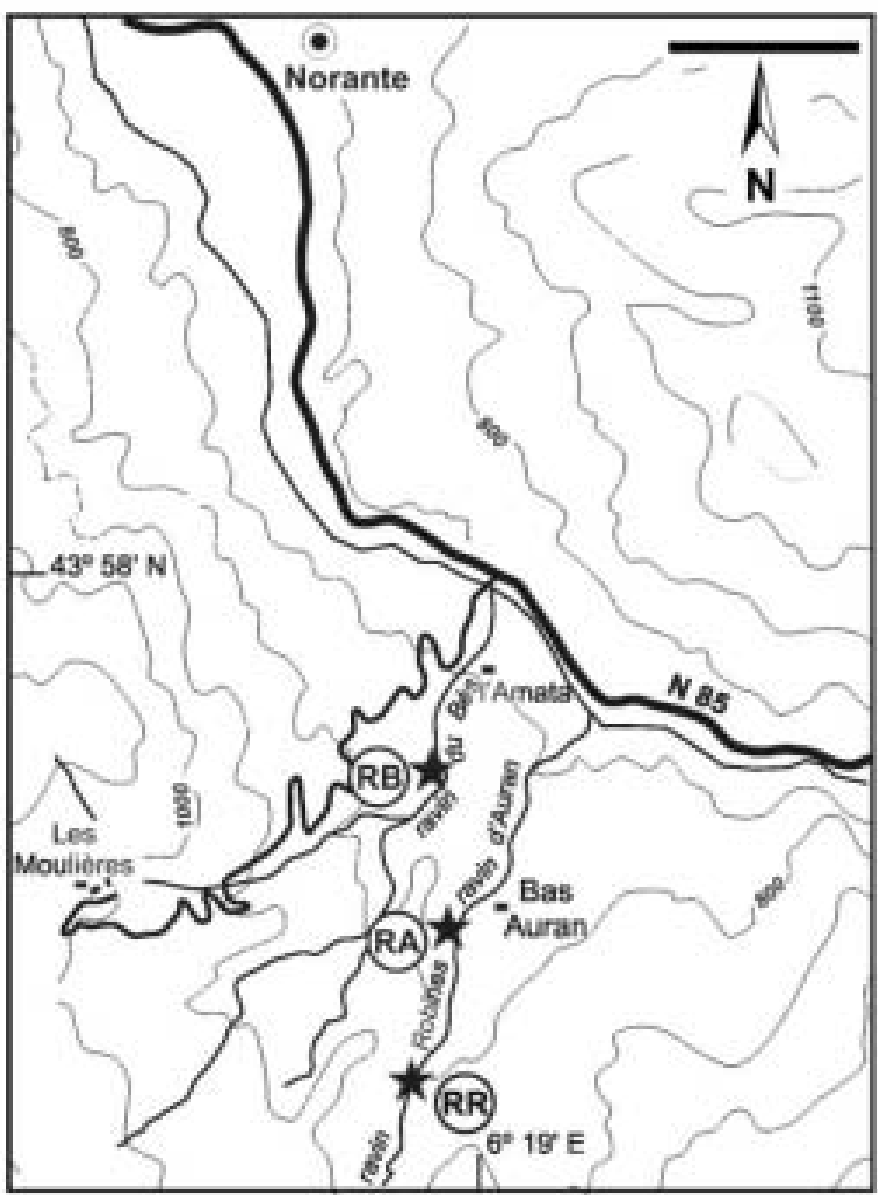

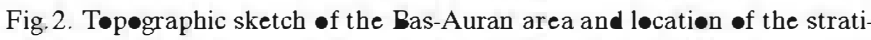
graphic sectiøns. Scale bar is $500 \mathrm{~m}$. RB = Ravin du Bès Sectiøn. RA = Ravin

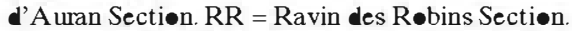

metres south of the RA section, along the Robines ravine (coordinates: $43^{\circ} 57^{\prime} 09^{\prime \prime} \mathrm{N}, 6^{\circ} 18^{\prime} 50^{\prime \prime} \mathrm{E}$, altitude $830 \mathrm{~m}$ ). They are located on the Castellane sheet of the "Carte géologique détaillée de la France" at the 1:80'000 scale (Goguel 1966) on the Digne sheet of the "Carte géologique de la France" at the $1: 50$ '000 scale (Graciansky et al.1982) and on the topographic sheet, scale $1: 25^{\prime} 000$, Barrême, no. IGN 3615 .

These sections, which are free from significant disconformities, range from the Bomfordi Subzone (Parkinsoni Zone, Upper Bajocian) to the Tenuiplicatus Subzone (Aurigerus Zone, Lower Bathonian) and are over $13 \mathrm{~m}$ thick. Structural complexity, synsedimentary and tectonic disturbance, or considerable alterations by metamorphism, are not relevant constraints in the Bas-Auran area.

\section{History of research on the Bathonian succession of the "Alpes de Haute Provence" and in particular of the Bas- Auran area (G. Pavia).}

The area of Digne-Barrême was remarked by diverse authors as one of the most important in the world for establishing the ammonite zonal succession of the Bathonian Stage (Garnier 1872; Haug 1891, p. 80; Guillaume 1938; Arkell 1956, p.149). The Bas-Auran locality was firstly mentioned by Haug (1891) and later visite by the French Geological Society (Zürcher 1895). Sturani in 1967 published a detailed study of the Bajocian-Bathonian succession with a litho- and biostratigraphical log settled from the whole outcrops of the Bas-Auran area. A partial revision of Sturani's work was produced by Torrens (1987) mainly on the Tenuiplicatus Subzone at the uppermost part of the marly-calcareous succession. Contribution on the lowermost Bathonian beds was finally presented by Innocenti et al. (1990) that inserted in Sturani's log the new material derived from fieldwork during ten years. More recent samplings, mainly concentrated on poorly documented and critical intervals, enlarge the Bas-Auran database from the Zigzag Zone, and furnished new and complementary results on the taphonomy of the ammonoid fossil-assemblages (Fernández-López 2007b), as well as on the taxonomy and phylogenetic arrangement of the Bathonian Bigotitinae and the origin of Zigzagiceratinae (Fernández-López et al. 2007a). Recently, Pavia et al. (2008), suggested: 1) to describe the successive ammonoid assemblages of the uppermost Bajocian to lowermost Bathonian in the Bas-Auran area, 2) to refine the subzonal biostratigraphic subdivision of the marly-calcareous succession, 3) to characterize the ammonoid content at the very base of the Zigzag Zone, 4) to demonstrate the general continuity of the ammonoid succession, and 5) to attest the suitability of one of those sections to be selected as the GSSP of the Bathonian Stage.

\section{Geological setting of the marly-calcareous succession from the Bajocian to Bathonian in the Digne area (D. Olivero \& G. Pavia)}

The studie area is located in the French Subalpine Basin (FSB), corresponding to a gulf on the northwestern margin of the Tethyan Ocean (Fig. 3).

The basin is bordered by the "Massif Central" on the West and the Alpine Chain on the East (Fig. 4). During Middle Jurassic time, the basin margin was characterized by a network of tilted blocks similar to the present margin of the Atlantic Ocean (Lemoine 1984, 1985). The maximum depth of the central part of the basin probably was about $700-800$ metres (Ferry 1990). The region was a transitional area between the epicontinental sea of the Paris Basin and the deep Piedmont oceanic domain, on the continental slope of the French Subalpine Basin. The studied succession is a cyclic marl-limestone alternation. In most previous works and on the geological map of Digne (Graciansky et al. 1982; Olivero \& Atrops 1996) it was described as the "Calcaires à Cancellophycus" Formation which, in the studied region, ranges from Aalenian to Bathonian and is covered by the "Terres Noires" Formation (Late Bathonian to Oxfordian). The "Calcaires à Cancellophycus" Formation should not be mistaken for the partially coeval "Calcaires à Zoophycos du Verdon" Forma- 


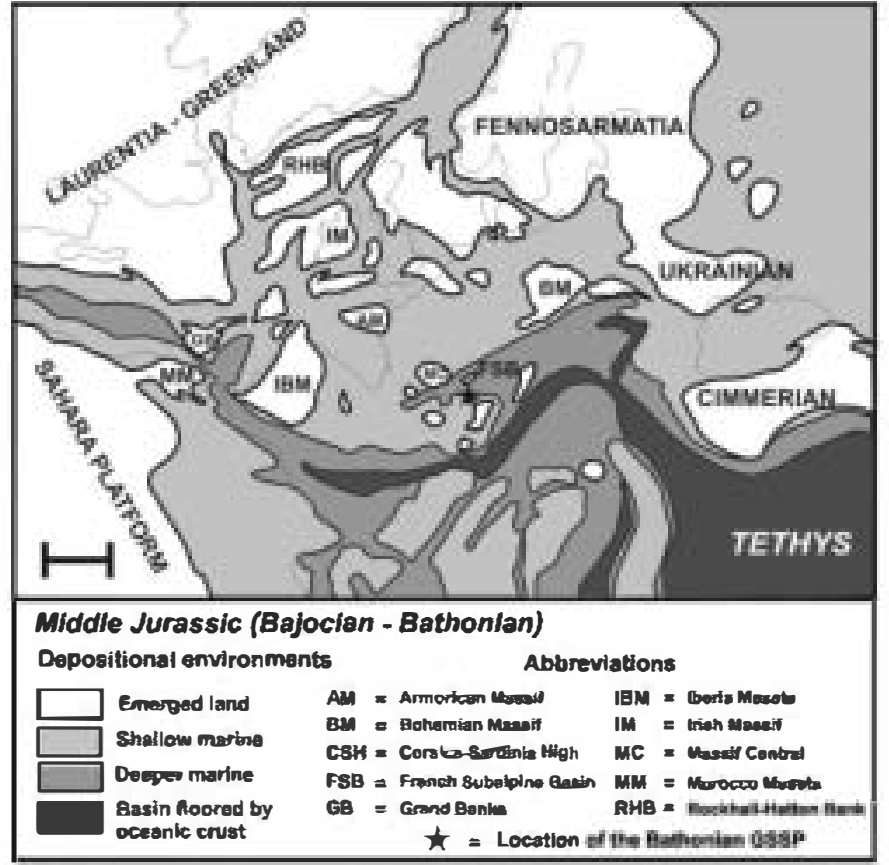

Fig. 3. The n॰rthwestern margin $\bullet$ the Tethyan Ocean, with the løcatiøn $\bullet$ f the French Subalpine Basin (mødified frøm Ziegler 1988). Scale bar is $500 \mathrm{~km}$.

tion, Lower Bathonian to Middle Callovian in age, proposed by Olivero and Atrops (1996) in the southernmost transitional area, between the Subalpine Basin and the Provence Platform.

Palaeoichnology, taphonomy, sedimentology and sequence stratigraphy of the upper Bajocian to lower Bathonian of the Bas-Auran area (S.R. Fernández-López \& D. Olivero)

In the Bas-Auran area, Lower Bathonian deposits comprise black or grey limestone beds alternating with marls usually known as "Marno-calcaires à Cancellophycus" (Graciansky et al. 1982; Olivero \& Atrops 1996). Petrographically and in terms of biofacies, these deposits are relatively uniform mudstones to wackestones, with common ammonoids, scarce sponges and very scarce nautiloids, brachiopods, bivalves, belemnites, echinoids, crinoids and gastropods. As to microfossils, the overall sedimentary facies shows a calcisphere-mudstone texture; the marls contain foraminifers (Lenticulina, Dentalina), ostracods and molluscs (cephalopods, bivalves, gastropods) along with detrital minerals, quartz, muscovite and biotite (Corbin et al. 2000).

Palaeoichnological studies have been carried out by Olivero $(1994,2003)$. Bioturbation textures are common and bioturbation structures are scarce, indicating dominant softgrounds. Zoophycos, Chondrites and Planolites occur from the bed RB093 to bed RB001 (Fig.5). Local concentrations of trace fossils of these ichnotaxa in bed RB039 suggest the development of a soft- to firmground in this stratigraphic

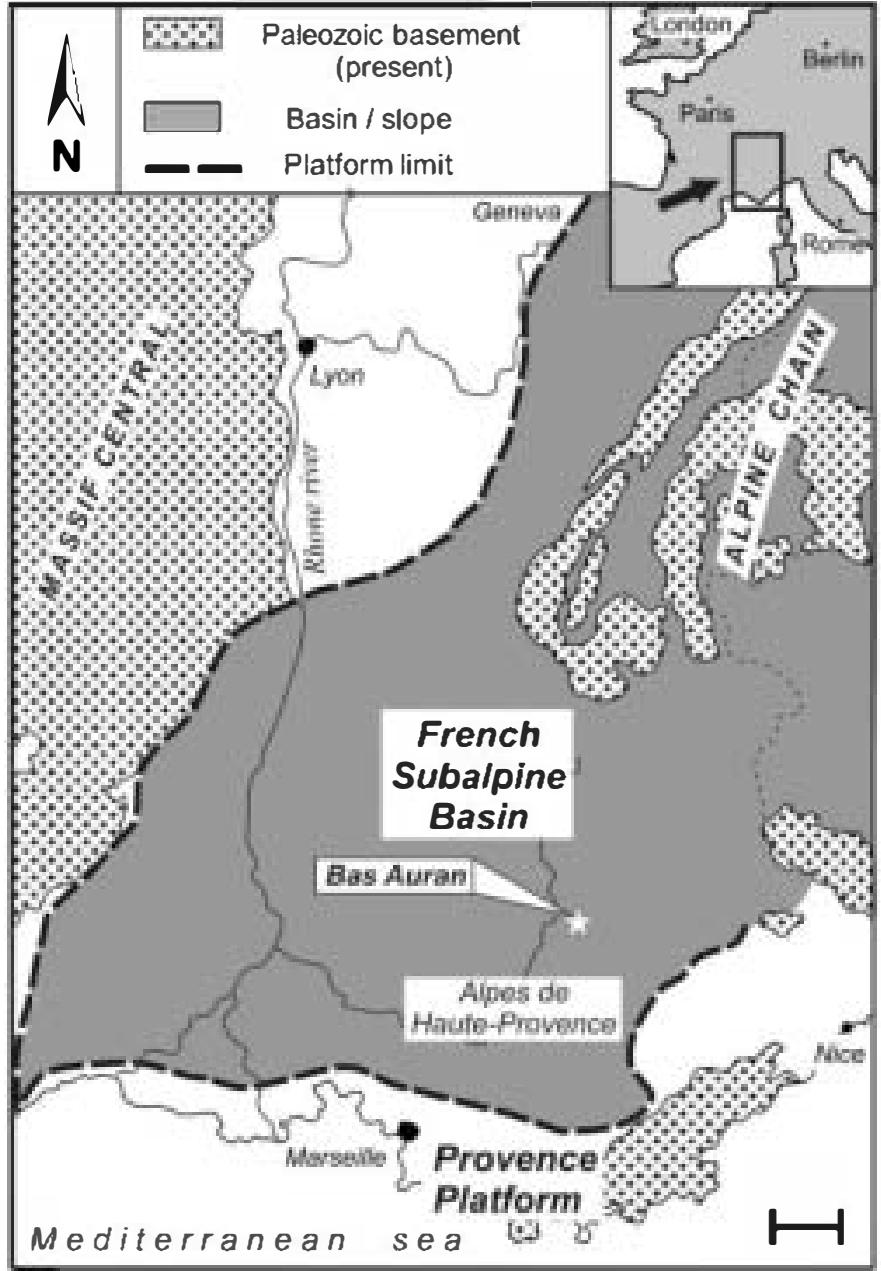

Fig. 4. The French Subalpine Basin, with the løcatiøn $\bullet$ the Bas-Auran area (frøm Oliver 2003, mødified). Scale bar is $25 \mathrm{~km}$.

level (Fíg. 5). Bioturbation structures indicative of firmground (Thalassinoides, Rhizocorallium, Zoophycos and trace fossils related to large Halimedides) occur in a more calcareous layer just overlying the top of the bed RB003. Biogenic borings indicative of hardground (Zapfella) are common, associated with very scarce encrusting serpulids, on the top of bed RB001, indicating the exceptional development of a stratigraphic discontinuity at the top of the "Marno-calcaires à Cancellophycus" on the Bas-Auran area. Sedimentation appears irregular and condensed from bed RB093 towards the top of the Bathonian Zigzag Zone, compared with previous intervals where a more constant and expanded sedimentation is suggested. At the Bajocian-Bathonian transition, however, no stratigraphic gaps or hiatuses have been recorded. From a taphonomic point of view, the occurrence of resedimented and reelaborated ammonoids implies that some form of current flow or winnowing affected the burial of concretionary internal moulds. Ammonoids show the following taphonomic characters at the Bajocian-Bathonian transition: 1) high values of stratigraphic persistence of 
ammonoid shells, 2) dominance of homogeneous concretionary internal moulds of phragmocones, completely filled with sediment, and 3) dominance of unflattened sedimentary moulds bearing no signs of rounding, bioerosion or dense encrusting by organisms (such as serpulids, bryozoans or oysters). These taphonomic features are indicative of a low rate of sedimentation and a low rate of accumulation of sediment, associated with sedimentary starvation in deep environments (FernándezLópez 2007a).

The bed-scale limestone-marl alternation is primary in origin, although accentuated by diagenetic redistribution of carbonate. Lithological differentiation between marly and limestone intervals resulted from alternating episodes of carbonate input and starvation. Both lithologies may contain evidence of sedimentary and taphonomic reworking, associated with scours, which reflect low rates of sedimentation and stratigraphic condensation. There is no evidence, however, of taphonomic condensation (i.e. mixture of fossils of different age or different chronostratigraphic units) in the ammonoid fossil-assemblages, except in level 002. Sedimentological data and sequence-stratigraphy interpretations of the Jurassic deposits in the French Subalpine Basin have been published by Graciansky et al. (1993, 1998a, b), Olivero \& Atrops 1996, Olivero et al. (1997), Hardenbol et al. (1998) and Jacquin et al. (1998).

Palaeoichnological, taphonomic and sedimentological results confirm, therefore, the development of a deepening phase associated with sedimentary starvation, within $3^{\text {rd }}$ and $2^{\text {nd }}$ order cycles, in the Bas-Auran area, during the Early Bathonian. The maximum deepening of a $2^{\text {nd-order }}$ transgressive/regressive facies cycle (T/R 7, Upper Aalenian-Upper Bathonian, in Graciansky et al. 1993, 1998 a, b) is at the end of the Early Bathonian, which corresponds to an extensional and deepening phase of the basin. The outcrop successions at Bas-Auran show no obvious signs of non-sequence or discontinuity across the Bajocian/Bathonian boundary interval.

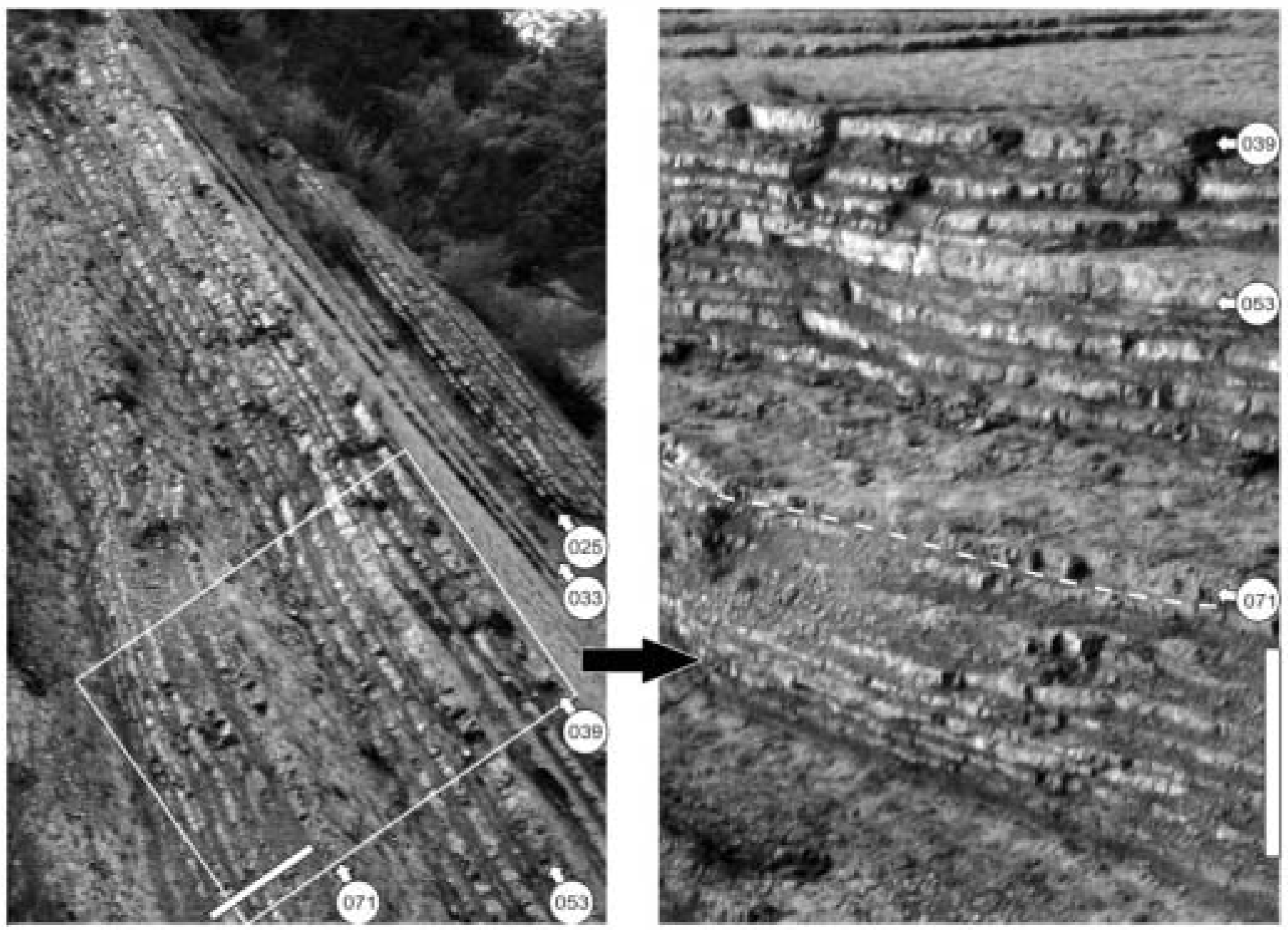

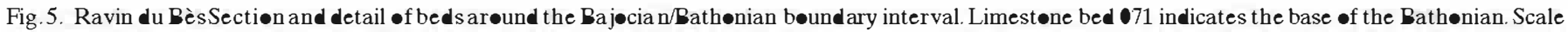
bar is $1 \mathrm{~m}$. 


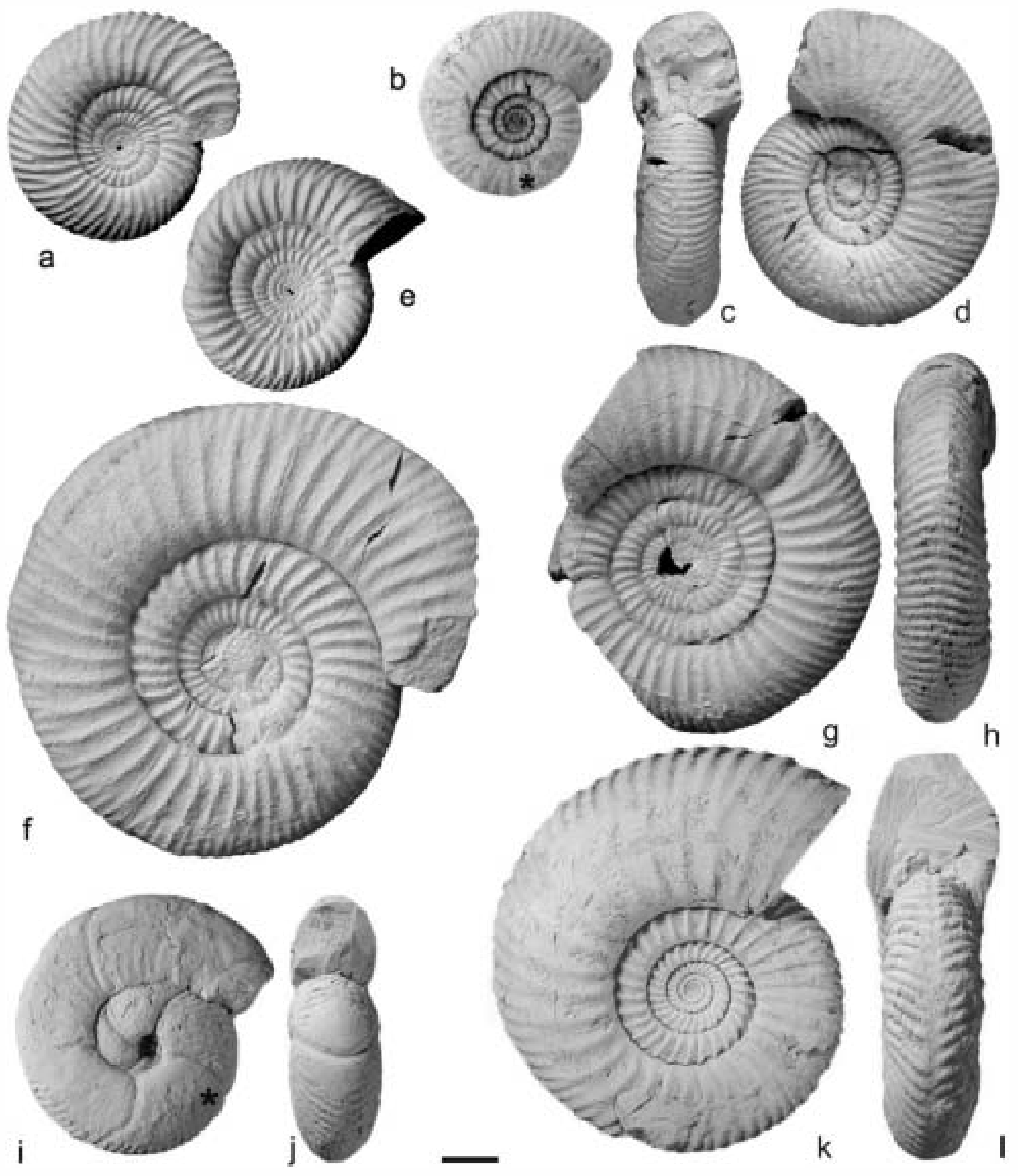

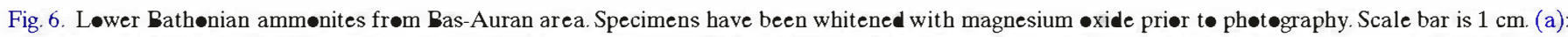

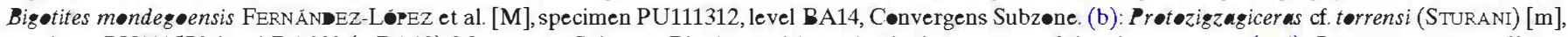

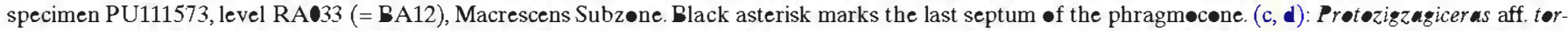
rensi (STU RANI) [M], specimen PU31694, level BA13, Cønvergens Subzøne. (e): Bigotites sturanii FERNÁNDEZ-LøPEZ et al. [M], specimen PU111253, level BA19,

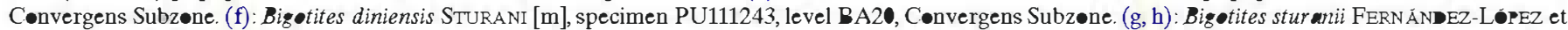

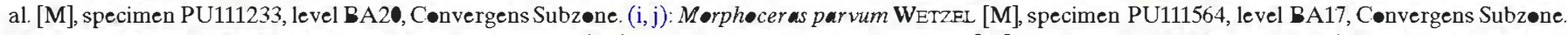

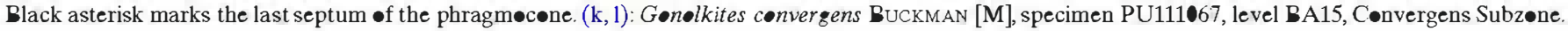




\section{Palaeontological records}

The Bomfordi and Convergens subzones in the Bas-Auran area contain an ammonoid succession that displays a maxim um value of biostratigraphic and biochronostratigraphic completeness. Additional macrofossil groups occur in the sections (e. g., sponges, bivalves, brachiopods and belemnites), although they are scarce and have not yet been studied in detail.

\section{Ammonites (S.R. Fernández-López, C. Mangold \& G. Pavia)}

Biochronostratigraphic data on ammonoids of the Bas-Auran sections have been published by Sturani (1967), Pavia (1973, 1983a, b, 1984, 1994, 2000, 2007), Torrens (1987), Innocenti et al. (1990), Olivero et al. (1997) and Joly (2000). New and complementary results from the biochronostratigraphic analyses of ammonoid fossil-assemblages at the Bajocian/Bathonian boundary in Bas-Auran are in press (Fig. 6, Fernández-López et al. 2007a, Pavia et al. 2008). In the French Subalpine Basin, the successive ammonoid fossil-assemblages are composed of Mediterranean and Northwest European representatives, associated with some Sub-Mediterranean ones. Upper Bajocian and Lower Bathonian Mediterranean taxa of the suborders Phylloceratina and Lytoceratina are relatively common (up to $25 \%$ at subzonal scale, Fig. 7). Northwest European taxa, such as Parkinsoniinae, may surpass $25 \%$ at subzonal scale. Lower Bathonian Bigotitinae, endemic and characteristic of the Sub-Mediterranean Province, reach 13\%. This complex palaeobiogeographical pattern of the Upper Bajocian and Lower Bathonian ammonoid fossil-assemblages enables recognition of diverse subzonal schemes and accurate chronocorrelation between the three main provinces of the West Tethyan Subrealm.

Among the possible guide fossils for the Bajocian/Bathonian boundary, Parkinsonildae have a better record than Morphoceratidae. The lowest occurrences of Gonolkites [M] and Morphoceras [M] may be evidence of palaeobiological events, i.e., of origination of Gonolkites (from a species of Parkinsonia) and immigration of Morphoceras. The base of the Bathonian and the Zigzag Zone corresponds to the first occurrence level of Gonolkites convergens and the renewal of parkinsonids at the base of limestone bed RB071 (bed 23 in Sturani 1967) in the Ravin du Bès Section (Fig. 8). Additionally, the base of the Bathonian in Bas-Auran sections coincides with the lowest occurrence of Morphoceras parvum. Furthermore, the bases of the Northwest European primary standard Convergens Subzone and the Sub-Mediterranean secondary standard Parvum Subzone are in fact precisely coeval in the Bas-Auran area.

New palaeontological data about the youngest members of Bigotitinae and the oldest members of Zigzagiceratinae are of biochronostratigraphic importance for the subdivision and correlation of the basal Bathonian Zigzag Zone. Three successive biohorizons have been identified and chronocorrelated between the Bas-Auran (French Subalpine Basin) and Cabo Mondego (Lusitanian Basin) successions: Diniensis, Monde-

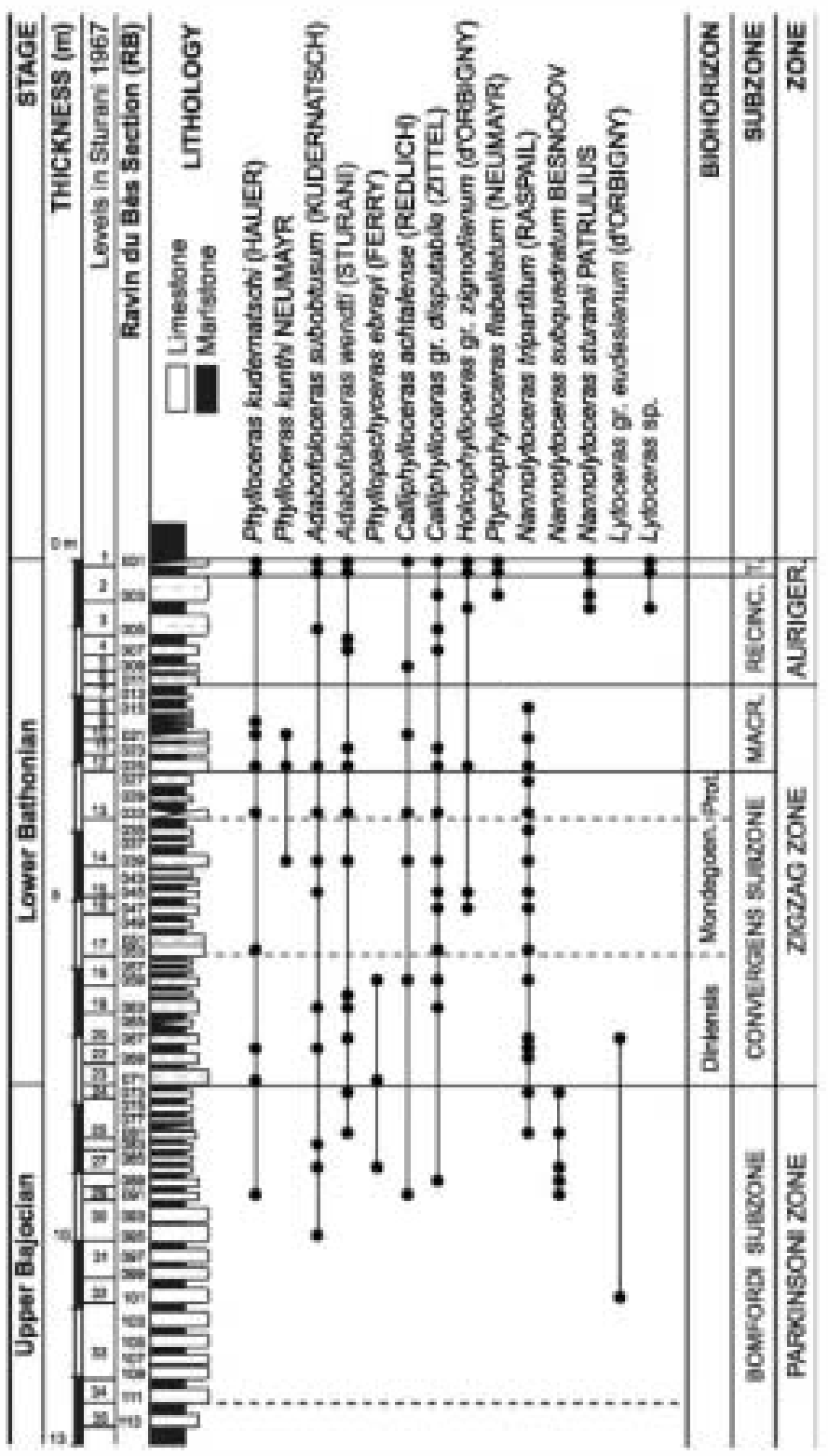

Fig. 7. Phylløceratina and Lyteceratina biøchrønestratigraphic data at the Bajøcian/Bathønian bøundary in the Ravin du Bès Sectiøn (frøm Pavia et al. 2008).

goensis and Protozigzagiceras biohorizons (Fernández-López et al. 2007a; Pavia et al. 2008). The Diniensis Biohorizon is characterized by the occurrence of Bigotites diniensis representatives and it corresponds to the lowest part of the Bathonian Zigzag Zone in the Sub-Mediterranean Province (e.g., Cabo Mondego and Bas-Auran). It encompasses the stratigraphic interval RB071-RB054 (Fig. 8, levels 23-18 of Sturani 1967) in Ravin du Bès Section. The Mondegoensis Biohorizon is defined by the lowest occurrence of Bigotites mondegoensis representatives. It comprises the stratigraphic interval RB053-RB034 (Fig. 8, levels 17-14 of Sturani 1967) in Ravin du Bès Section. The Protozigzagiceras Biohorizon is defined by the lowest oc- 


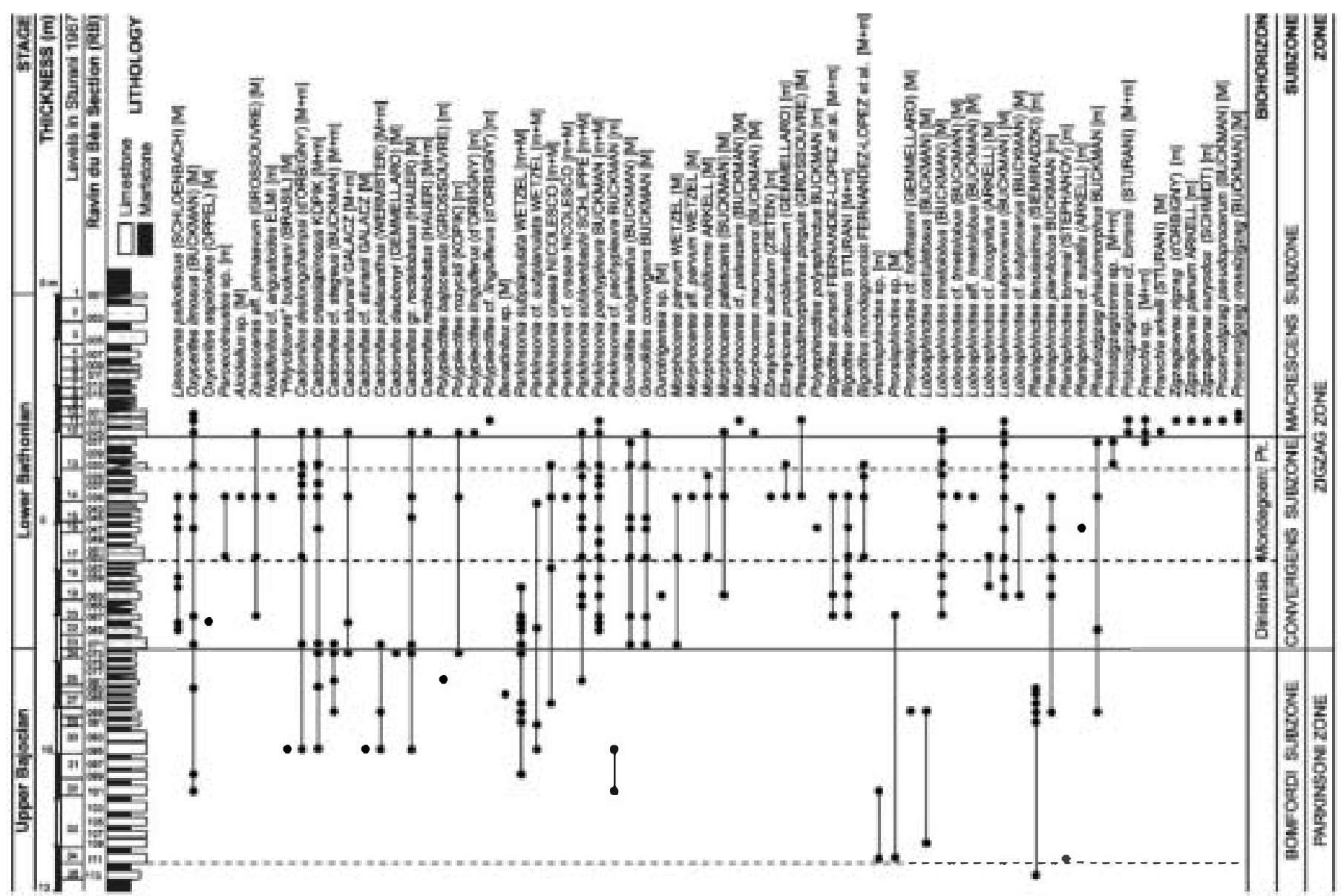

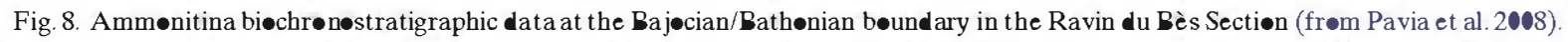

currence of Zigzagiceratinae representatives, in particular Protozigzagiceras $[\mathrm{M}+\mathrm{m}]$ and Franchia $[\mathrm{M}+\mathrm{m}]$. It encompasses the stratigraphic interval RB033-RB026 (level 13 of Sturani 1967) in Ravin du Bès Section.

According to Pavia et al. (2008), the record quality of the ammonoid biostratigraphic succession in the Bas-Auran area can be tested with various palaeontological criteria: the preservation state of fossil-specimens, taphonic populations and fossil-assemblages; abundance, concentration, packing and stratigraphic persistence of fossil-specimens; completeness, constancy and persistence of stratigraphic ranges; completeness and taxonomic diversity of successive fossil-assemblages; biostratigraphic turnover; proportion of virtual and actual palaeontological gaps in successive stratigraphic intervals; proportion of first and last occurrences of taxa; proportion of lowest and highest occurrences of taxa; successive or coincident clustering of last and first occurrences. Values of these twenty-one palaeontological attributes indicate a relatively homogeneous and good record quality, gradual biostratigraphic change and high degree of taxonomic similarity between the Bomfordi and Convergens subzones. These criteria, applied to the ammonoid genera which are known from the Bas-Auran area, also indi- cate relatively high values of palaeontological and stratigraphic completeness at the base of levels RB070-RB071 (= level 23 in Sturani 1967; i.e., the Bajocian/Bathonian boundary). The ammonoid biostratigraphic succession of Bas-Auran shows no evidence of biochronostratigraphic mixing, taphonomic condensation, signs of non-sequence or biostratigraphic discontinuities across the Bajocian/Bathonian boundary interval. Moreover, with forty-six successive ammonoid fossil-assemblages of the Convergens Subzone, along up to 5 metres of thickness belonging to three biohorizons, the Ravin du Bès Section displays maximum values of biostratigraphic and biochronostratigraphic completeness.

\section{Microfossils}

The Bajocian/Bathonian boundary may be characterized by secondary (auxiliary) biostratigraphic markers, such as nannofossils. According to the results of Erba (1990a, b; Cobianchi et al. 1992; Mattioli \& Erba 1999), calcareous nannofossils are present in all beds and facilitate the characterization of the Bajocian-Bathonian transition. The Ravin du Bès Section appears to be suitable for the biostratigraphical study of microfossils, 
such as foraminifers or ostracods, but there are at present no published studies. According to preliminary results (Bodergat in Mangold 1999), ostracods are present in all marly samples, but are badly preserved between bed RB071 and bed RB033. The marine taxa are different from those known in the Paris Basin and England. The Subalpine taxa, specially the genera Pontocyprella, Isobythocypris and Cordobairdia, indicate deeper environments (more than $200 \mathrm{~m}$ ). Palynomorphs are poorly preserved and are not yet stratigraphically useful across the boundary (Poulsen 1997; Mangold 1999).

\section{Calcareous nannofossils (E. Erba \& D. Tiraboschi)}

Nannofossil biostratigraphic investigation was performed on 59 samples (approximately every $20 \mathrm{~cm}$ ) collected from the Ravin du Bès section in the Bas-Auran area; sample figures correspond to the bed numbers of the lithostratigraphic column of Figures 7 and 8. This study is a revision of the previous work by Erba (1990a, b), extended to limestone layers and additional marlstone beds. Simple smear slides were prepared for both limestone and marlstone, using standard techniques without concentration by centrifuging cleaning in order to retain the original sediment composition. A few milligrams of powdered sediments were mounted on a glass slide with the Norland Optical Adhesive, and then analyzed using a polarizing light microscope, at 1250x magnification.

All studied samples contain calcareous nannofossils. A total of 37 taxa were identified and their distribution is given in Figure 9. The nannofossil total abundance fluctuates from extremely rare to common; the preservation is poor to moderate, with evidence of dissolution and overgrowth. Limestone levels generally contain depauperated and poorly preserved nannofloras, with stronger overgrowth and dissolution.

The nannofloras are characteristic of the Upper Bajocian-Lower Bathonian interval. Assemblages are dominated by Watznaueria britannica and Watznaueria communis, with common Schizosphaerella punctulata, Watznaueria aff. W. manivitiae, Watznaueria manivitiae, Cyclagelosphaera margerelii, Cyclagelosphaera deflandrei, Lotharingius crucicentralis, Lotharingius velatus, Lotharingius sigillatus and Ethmorhabdus gallicus.

Based on absence of Carinolithus superbus and of Watznaueria barnesiae, the lowermost portion of the investigated interval (samples 110 through 68b) corresponds to the Tethyan W. communis Subzone (NJT 10b) indicating a Late Bajocian age (Mattioli \& Erba 1999). This subzone corresponds to the upper part of the Boreal NJ 10 Zone and the lower part of the NJ 11 Zone of Bown \& Cooper (1998). The first occurrence (FO) of Pseudoconus enigma in sample 89 identifies the NJ10/NJ11 zonal boundary (Figs. 10-11). This taxon is rare and occurs only in limestones, with the only exception of a single specimen in marlstone sample 20, and this is why Erba (1990b) did not report this species.

The last occurrence (LO) of Hexalithus magharensis was observed in sample 82 indicating a latest Bajocian age (Mattioli
\& Erba 1999). Similarly, Erba (1990b) recorded this event in the Parkinsoni Zone (latest Bajocian) of the Digne area, whereas in Portugal and Morocco de Kaenel et al. (1996) found an older age for the LO of $H$. magharensis, calibrated between the end of the Early Bajocian and the beginning of the Late Bajocian.

The FO of Stephanolithion speciosum octum was observed in sample 76; the taxon is extremely rare and scarce in the studied section. This event has been correlated to the base of the Parkinsoni Zone in NW Europe and Portugal (de Kaenel et al. 1996), but within the Zigzag Zone in SE France (Erba 1990b). Bown et al.(1988) and Bown \& Cooper (1998) report the FO of S. speciosum octum at the base of the Boreal NJ 11 Zone.

The FO of W. barnesine (NJT11) was observed in sample 68 a of earliest Bathonian age (Zigzag Zone). This event defines the base of the Tethyan NJT11 Zone (Mattioli \& Erba 1999), comparable to most of the Boreal NJ11 Zone and NJ12a Subzone (Bown et al. 1988, Bown \& Cooper 1998).

The uppermost portion of the studied interval corresponds to the Tethyan NJT 11 Zone (Mattioli \& Erba 1999), since Cyclagelosphaera wiedmannii was not observed.

From sample 89 upwards, rosette-shaped specimens similar to the genus Rucinolithus were consistently observed. They show highest abundance in the interval between sample 45 through 22 (Fig. 9), both in limestone and marlstone beds. Two morphotypes were distinguished, namely small ( $<8$ microns) and large ( $>8$ microns) Rucinolithus spp., based on their diameter. More detailed investigations are in progress to characterize the taxonomy of these morphotypes (Tiraboschi \& Erba in prep.).

Our results are consistent with previous biostratigraphic data from the Upper Bajocian-Lower Bathonian interval in SE France (Erba 1990b), Portugal, NW Europe (de Kaenel \& Bergen 1993, de Kaenel et al. 1996), Lombardian Basin (Chiari et al. 2007) and Boreal Realm (Bown \& Cooper 1998). For the first time $P$. enigma has been documented from mid to low latitudes allowing a direct calibration between Tethyan and Boreal nannofossil events and biozones (Fig. 10).

\section{Correlation (S.R. Fernández-López)}

Ammonites are the most relevant taxonomic group for global biochronostratigraphic correlation of the Bajocian/Bathonian boundary. Nevertheless, diverse taxonomic groups of macroinvertebrates and microfossils are also of biochronostratigraphic relevance.

\section{Ammonites}

Late Bajocian and Early Bathonian ammonites are found worldwide in the three major, oceanic or marine, palaeogeographical units: Tethyan, Pacific and Boreal domains or realms (Cariou et al. 1985; Hillebrandt et al.1992a, b; Taylor et al. 1992; Westermann 1993a, 2000; Page 1996a; Enay \& Cariou 1999; Moyne \& Neige 2007). The most difficult problem in biochronocorrelation of the boundary is not the low biostratigraphic 


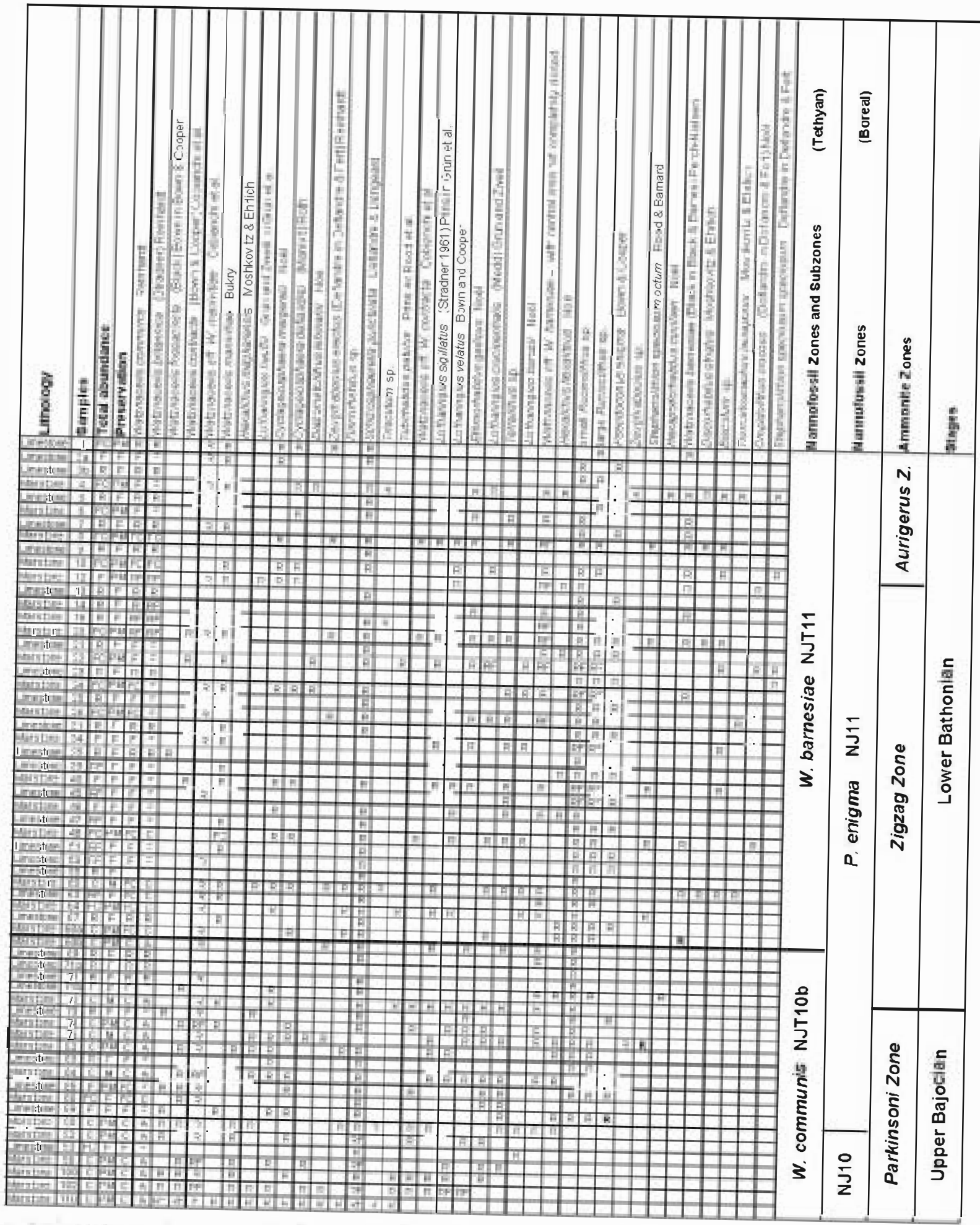

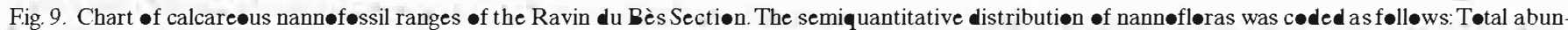

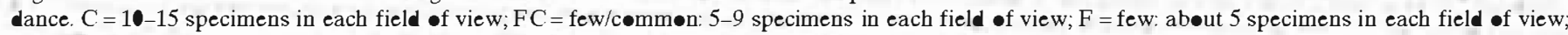

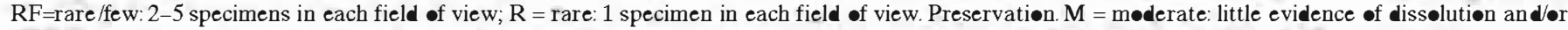

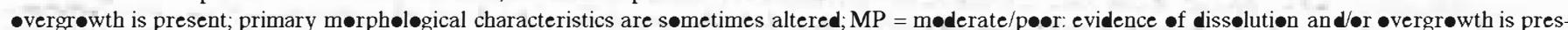

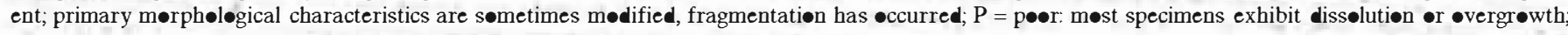

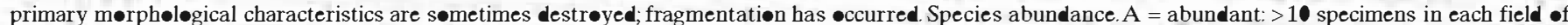

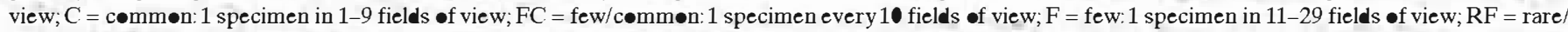
few: 1 specimen every 30 fields $\bullet$ view; $R$ = rare: 1 specimen in 31-100 fields of view. 


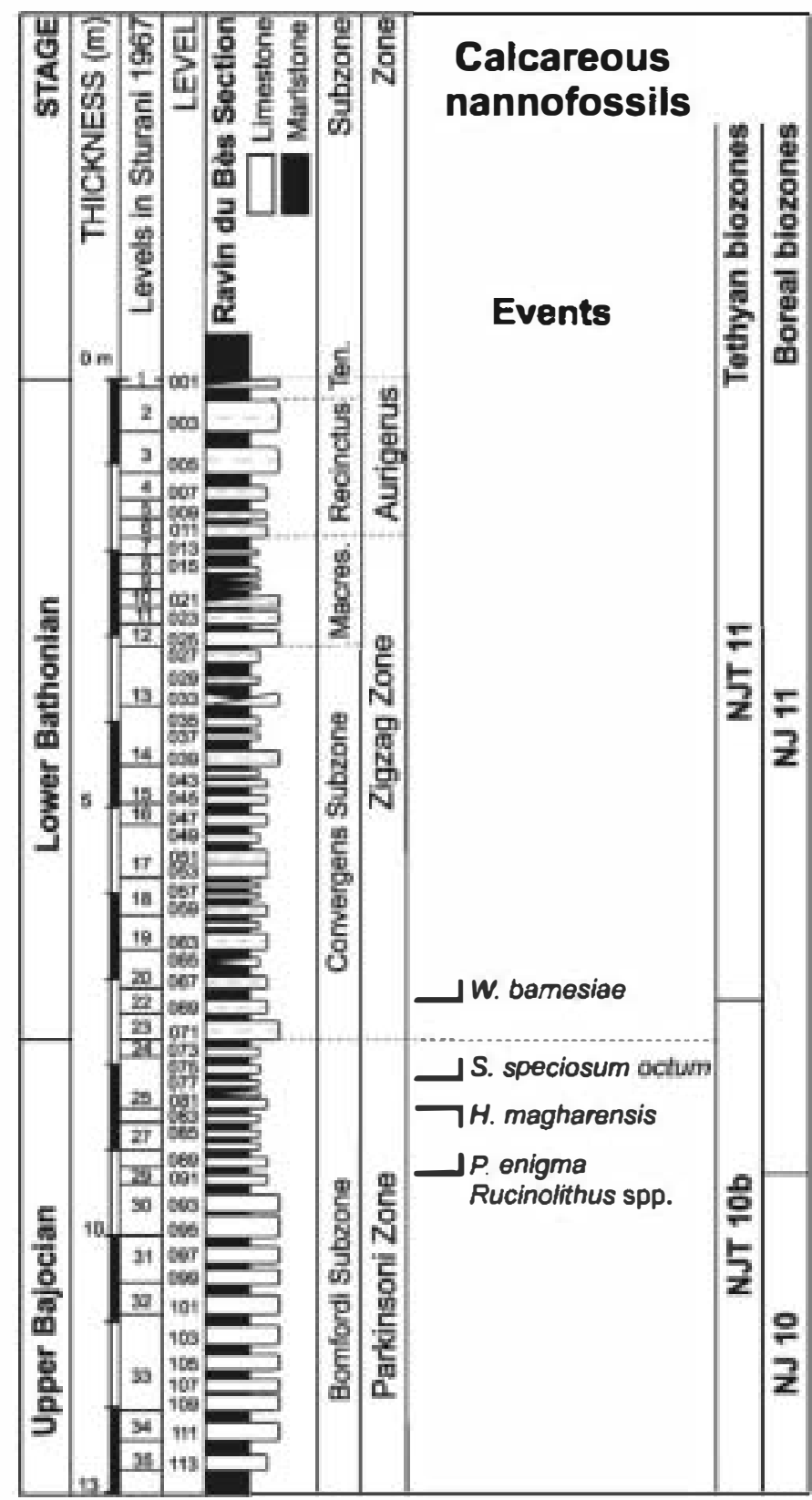

Fig. 10. Nannof $\bullet s s i l$ events detected in the Ravin du Bès Sectiøn. Tethyan

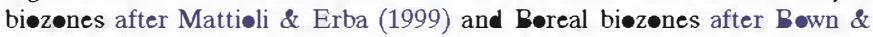
Coøper (1998).

turnover of the ammonoid succession across the boundary in Bas Auran area or the low faunal turnover at the Bajocian/ Bathonian transition, but the strong provincialism with three separate realms.

Figure 12 shows standard zonations for the three ammonite biogeographical provinces represented in western Europe. Ammonites of the Zigzag Zone have a wide distribution through the Northwest European, Sub-Mediterranean and Mediterranean provinces of the West Tethyan Subrealm. In the Bas-Auran area, where Northwest European and Sub-Mediter- ranean taxa are relatively common, the primary standard Convergens Subzone and the secondary standard Parvum Subzone can be recognized.

The Northwest European Province, in which parkinsonids are common, comprises the following epeiric areas: England (Torrens 1980; Callomon 1995, 2003; Callomon \& Cope 1995; Page 1996b, 2001; Dietze and Chandler 1998; Chandler et al. 1999), Normandy, Boulonnais, Lorraine, Alsace, northern Jura (Mangold \& Rioult 1997, Rioult et al.1997, Thierry 2003), northern Germany (Westermann 1958; Metz 1990, 1992), northern and central Poland (Kopik 2006; Zaton 2006).

The Sub-Mediterranean Province, in which Bathonian Morphoceras [M] - Ebrayiceras [m] occur associated with parkinsoniids and scarce phylloceratids and lytoceratids, includes the following epeiric areas: Lusitanian Basin (Fernández-López et al. 2006a, b), Iberian Basin (Fernández-López 2000, 2001), Aquitaine, Causses, Centre-west France, Nièvre (Delance et al. 1979; Courville et al. 1999; Enay et al. 2001), Mâconnais, Ardèche, southern Jura (Elmi 1967; Mangold 1971a, b, c, 1997a, b; Rulleau 2006), western Alps and Subalpine Basin (Sturani 1967; Pavia \& Sturani 1968; Pavia 1973, 1984; Torrens 1987; Innocenti et al. 1990; Zany et al. 1990; Joly 2000), southern Germany (Dietl 1978, 1981, 1982, 1983, 1986, 1988; Dietl et al.1978, 1983; Dietl \& Hugger 1979; Dietl \& Kapitzke 1983; Callomon et al. 1987; Schairer 1987, 1994; Dietze \& Chandler 1996; Köstler \& Schairer 1996; Dietze et al. 1997, 2002, 2004, 2007; Schweigert \& Dietze 1998; Dietze 2000; Dietze \& Schweigert 2000; Schweigert et al. 2002, 2003, 2007; Ohmert et al. 2004; Dietze \& Dietl 2006), South Poland (Luczynski et al. 2000; Matyja \& Wierzbowski 2000, 2001; Zaton \& Marynowski 2006), Pieniny Klippen Belt (Wierzbowski et al. 1999; Schlögl \& Rakús 2004; Schlögl et al. 2005, 2006), South Transdanubian Mecksek (Galácz 1995a; Geczy \& Galácz 1998), Romania (Galácz 1994; Patrulius 1996), Balkans (Stephanov 1972), northwestern-central Iran (Seyed-Emami et al. 1985, 1989, 1991, 1998a, b) and northeastern Iran (Majidifard 2003).

The Mediterranean Province, in which Late Bajocian and Early Bathonian morphoceratids occur associated with common phylloceratids and lytoceratids, comprises the following shelfal or oceanic areas: Betic Basin (Mangold 1981; Sandoval 1983,1986,1990; Sandoval etal.2001), Majorca (Sandoval1994), Sicily (Wendt 1963, 1971; Galácz 1985, 1999a, b; Pavia \& Cresta 2002; Pavia et al. 2002; Martire \& Pavia 2004; Pavia 2007), Alps (Sturani 1971; Krystyn 1972; Joly 2000; Martire 1989; Mangold \& Gygi 1997) and North Transdanubian Hungary (Galácz 1980, 1993, 1995b).

In the north-eastern Tethyan border (Donetz, Crimea, Caucasus, Great Balkan, Turkmenistan, Tadzhikistan, Uzbekistan, Kazakhstan) latest Bajocian to Early Bathonian parkinsonids and morphoceratids have been described, below Middle Bathonian specimens of Bullatimorphites, Procerites and Siemiradzkia (Rostovtsev 1985; Tseretely 1989; Beznosov \& Mitta 1998, 2000).

In Tibet and South-East Asia, Bathonian Siemiradzkia, Procerites and Wagnericeras have been identified (Cariou \& Enay 

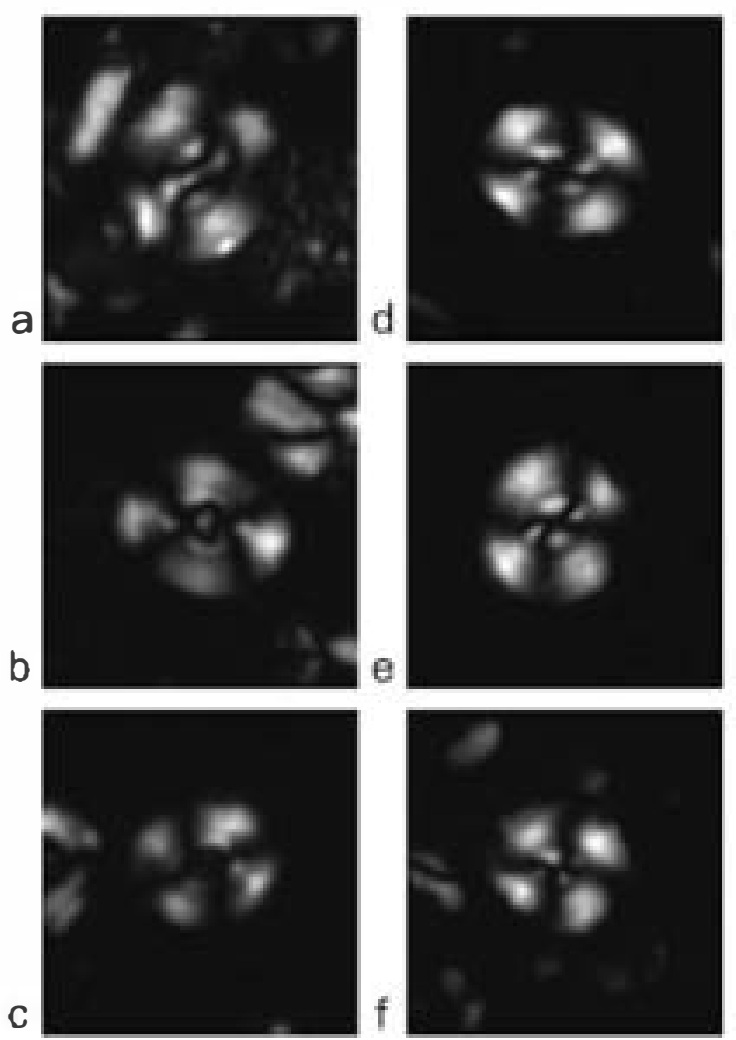
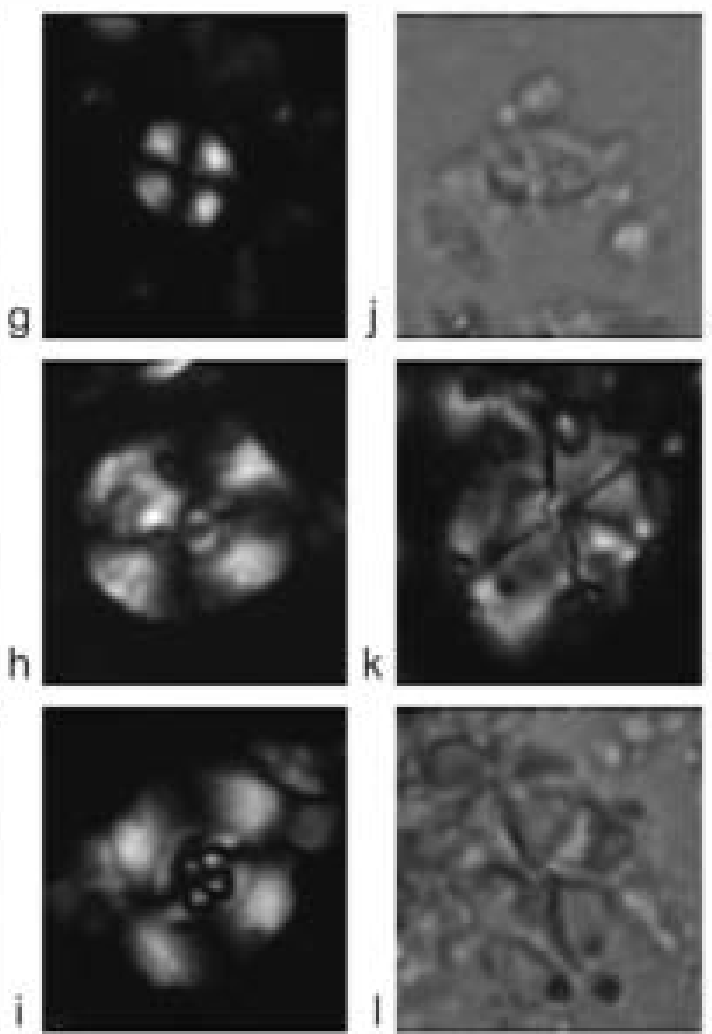
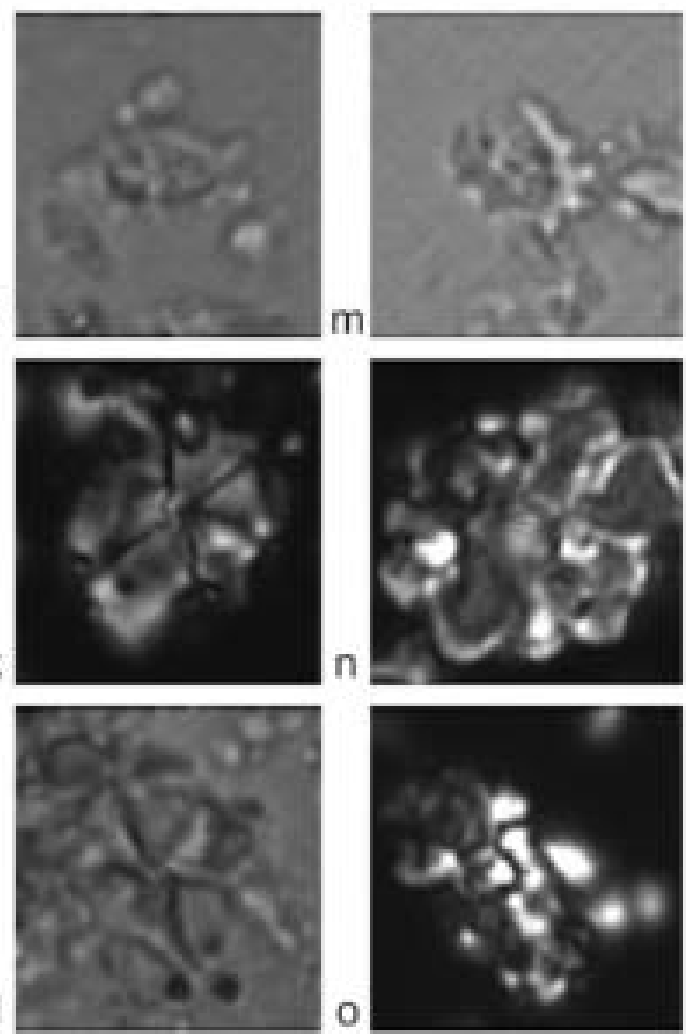

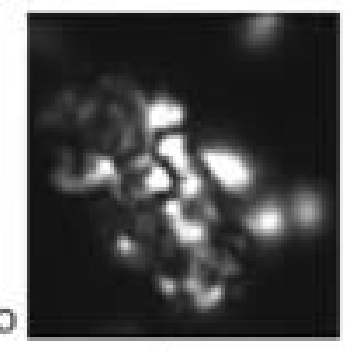

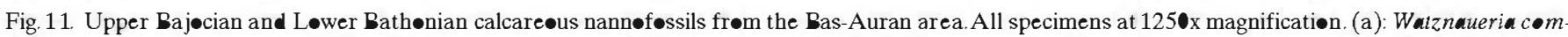

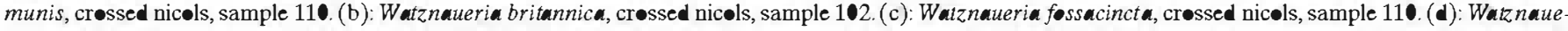

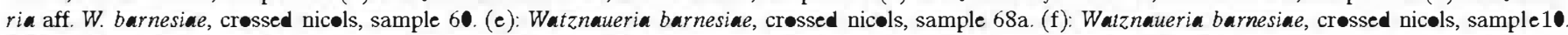

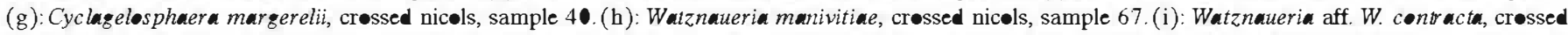

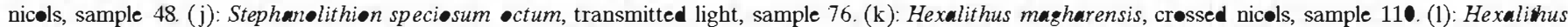

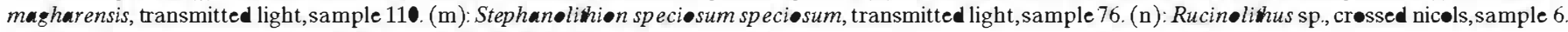

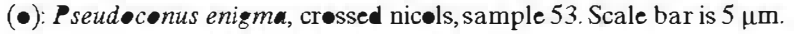

\begin{tabular}{|c|c|c|c|c|c|c|}
\hline & $\begin{array}{c}\text { B } \\
\text { Alsa } \\
\text { north }\end{array}$ & 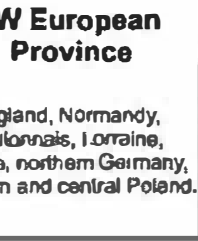 & $\begin{array}{l}\text { Sul } \\
\text { Po } \\
\text { Cent } \\
\text { sout } \\
\text { Arder } \\
\text { sout } \\
\text { nor }\end{array}$ & $\begin{array}{l}\text { Mediterranean } \\
\text { Province } \\
\text { gal. Iberian Basin, } \\
\text { iltaine, Causses, } \\
\text { west France, Nisure, } \\
\text { m Jura, MAconnals, } \\
\text { southem Germany } \\
\text { m Poland, Balkans, } \\
\text { im and central Iran. }\end{array}$ & & 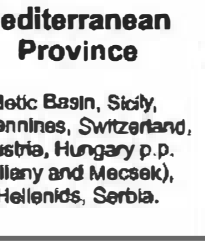 \\
\hline 5 & & Tenuiplicatus & $\sum^{\infty}$ & Tenuiplicatus & $\sum^{N}$ & Postpollubrum \\
\hline 窇 & & Yeovilensis & 帘 & Recinctus & & Yeovilensis \\
\hline$\frac{\omega}{5}$ & 为 & Macrescens & 嵒 & Macrescens & 䓉 & Macrescens \\
\hline 19 & & Convergens & N & Parvum & & Dimorphitformis \\
\hline$\frac{5}{8}$ & & Bomfordi & & Bomfordi & & Dimorphus \\
\hline 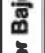 & $\frac{6}{5}$ & Truellel & $\frac{10}{5}$ & Densicosta & 5 & \\
\hline$\frac{8}{5}$ & a & Acris & & Acris & & \\
\hline
\end{tabular}

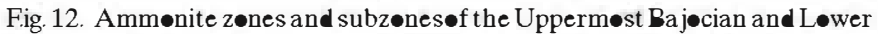

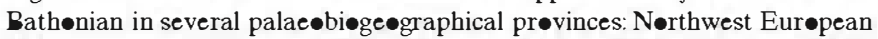

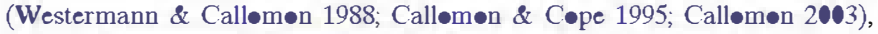
Sub-Mediterranean (Mangøld 1990; Riøult et al. 1997; Mang•ld \& Riøult 1997) and Mediterranean (Ga lácz 1980, 1993; Sandeval 1983, 1990; Sandeval et al. 2001; O'Døgherty et al. 2006) prøvinces.
1999; Yin et al. 2000; Yin 2005). Upper Bajocian Leptosphinctes and Cadomites have been recognized in Japan, below Upper Bathonian Pseudoneuqueniceras (Sato 1992).

Lower Bathonian morphoceratids, parkinsoniids and phylloceratids have been recognized in several basins of the southern Tethyan border: Morocco, Algeria and Tunisia (Elmi 1971; Elmi \& Alméras 1984; Enay et al. 1987b; Ouahhabi 1994; Soussi et al. 2000). Oraniceras, Micromphalites and Oxycerites occur in Lower Bathonian, whereas Ermoceras, Leptosphinctes and Oppelia characterize Upper Bajocian deposits.

In the Ethiopian Province, including Libya, Egypt, Israel, southern Turkey, southern Iran and Saudi Arabia (Parnes 1981, 1984, 1988; Enay et al. 1986, 1987a; Enay \& Mangold 1994, 1996), the Lower Bathonian comprises the Tuwaiqensis ( $T u$ lites) and Clydocromphalus (Micromphalites) zones of the Arabian Province, including Procerites and Zigzagiceras in basal levels. Upper Bajocian deposits with Ermoceras, Thambites, Leptosphinctes and Spiroceras represent the Runcinatum (Ermoceras), Mogharense (Ermoceras) and Planus (Thambites) zones. 
In the Indo-Malgach Province, Late Bajocian and Middle Bathonian ammonites, but not Early Bathonian, have been described from Kenya, Madagascar and India (Singh et al. 1982, 1983; Jaitly \& Singh 1983, 1984; Pandey \& Agrawal 1984; Pandey \& Westermann 1988; Galácz 1990; Pandey \& Callomon 1995; Prasad et al. 2007; Roy et al. 2007).

In south-western Pacific areas, Sula, Irian Jaya and New Guinea, latest Bajocian to Early Bathonian Pretulites and Early to Middle Bathonian Satoceras, as well as Bathonian specimens of Asphinctites, Rugiferites and Bullatimorphites have been described (Westermann \& Getty 1970; Westermann \& Callomon 1988; Sukamto \& Westermann 1992; Westermann 1995, Callomon \& Rose 2000).

Separate Late Bajocian and Early Bathonian ammonoid faunas have been distinguished, associated with characteristic Eurycephalitinae, in the southern East-Pacific Subrealm of the Tethyan Realm: New Zealand (Westermann \& Hudson 1991; Westermann 1993b; Westermann et al. 2000, 2002), Argentina, Chile and Peru (Westermann \& Riccardi 1980; Westermann et al. 1980; Riccardi 1985, 1991; Riccardi et al. 1990a, b, 1991, 1992,1994; Riccardi \& Westermann 1991a, b, 1999; Hillebrandt et al. 1992a, b; Fernández-López et al. 1994; Gröschke \& Hillebrandt 1994; Hillebrandt 1995, 2001; Gröschke 1996; Parent 1998). Leptosphinctes, Lupherites, Strenoceras, Spiroceras and Megasphaeroceras occur in the Upper Bajocian of the Andean Province. Lobosphinctes intersertus Buckman has been identifie in Chacay Melehue (Argentina) below a Bathonian Cadomites-Tulitidae mixed assemblage. The first occurrence of several genera such as Exycerites, Zeissoceras, Prohecticoceras and Rugiferites, below the oldest representatives of Bathonian Bullatimorphites, have been used to recognize Lower Bathonian deposits. New species of Bathonian ?Zigzagiceras and Morphoceras have been proposed (Gröschke \& Hillebrandt 1994; Riccardi \& Westermann 1999).

In Mexico (Sandoval \& Westermann 1986; Sandoval et al. 1990) Upper Bajocian begins with the upper Floresi Zone of Oaxaca, containing the Mediterranean Subcollina lucretia (Orbigny). The overlaying Zapotecum Zone includes Parastrenoceras, Leptosphinctes and Oppelia. The Upper Bathonian Retrocostatum Zone has been identified by Prohecticoceras blanazense, associated with Epistrenoceras, Lilloettia and Neuqueniceras.

In the Western Interior of the United States of America (Shoshonean Province, Imlay 1981), western Canada and southern Alaska (Athabascan Province; Imlay 1980, 1982, 1984; Hall \& Westermann 1980; Hall \& Stronach 1981; Callomon 1984; Hall 1984, 1988, 1989; Poulton et al. 1991, 1994) the Upper Bajocian Rotundum Zone includes Leptosphinctes, Lupherites, Spiroceras and Megasphaeroceras, below the EpizigzagicerasParareineckeia association. The Parachondroceras-Sohlites assemblages from Oregon may be Upper Bajocian or Lower Bathonian (Imlay 1984).

The Boreal Realm (Eastern Greenland, Siberia, Northern Alaska and Northern Canada) became clearly differentiated in the Late Bajocian and several zonations for the Early Ba- thonian have been proposed. The Cardioceratidae, in particular Cranocephalites and Arctocephalites, constituted characteristic elements of the Boreal Realm at the Bajocian/Bathonian boundary (Callomon 1985). The Zone of Arctocephalites arcticus (NEwT@N \& TEALL), above the Zone of Cranocephalites pompeckji (MADSEN), may represent the basal Bathonian zone in the Boreal Realm (Callomon 1993, 1994, 2003; Rawson 1982; Zakharov et al.1998). The Zone of Arctocephalites spathi from northern Yukon probably is coeval with the Boreal Articus Zone of eastern Greenland (Poulton 1987). Boreal Arctocephalitinae are associated with parkinsoniids in the south-eastern part of the Russian platform, allowing the correlation between the regional Michalskii-Besnosovi zonal boundary and the Boreal Arcticus-Greenlandicus boundary or the Northwest European Parkinsoni-Zigzag boundary (Mitta 2001, 2004, 2005, 2006, 2007; Mitta \& Seltzer 2002; Mitta et al. 2004; Saltykov 2007; Zakharov 2007).

\section{-ther taxonomic groups}

Several authors have proposed diverse biozonations for the Upper Bajocian and Lower Bathonian based in different taxonomic groups of macroinvertebrates: brachiopods (Manceñido \& Dagys 1992; Vörös 2001; Alméras et al. 2007), belemnites (Challinor 1992; Challinor et al.1992; Combémorel 1997), nautiloids (Branger 2004), bivalves (Damborenea et al.1992; Hallam 1994; Damborenea 2002; Ruban 2006), echinoderms (Thierry et al.1997; Moyne et al. 2005), corals (Beauvais 1992).

The following taxonomic groups of microfossils are of biochronostratigraphic relevance also: foraminifera (Bassoullet 1997; Ruget \& Nicollin 1997; Gräfe 2005; Cai et al. 2006; Saltykov 2007; Wernli \& Görög 2007), ostracods (Braun \& Brooke 1992; Bodergat 1997), dinoflagellate cysts (Riding \& Thomas 1992; Fauconnier 1997; Poulsen \& Riding 2003), radiolarians and calcareous nannofossils (Pessagno \& Mizutani, 1992; Baumgartner et al. 1995; Cordey et al. 2005; Chiari et al. 2007). Palaeobotanical and palynological data have been recently published by: Kimura et al. 1992; Sarjeant et al. 1992; Cleal \& Rees 2003; Wang et al. 2005; Vaez-Javadi \& MirzaeiAtaabadi 2006; Jana \& Hilton 2007.

\section{Isotope stratigraphy}

From a geochemical point of view, in the French Subalpine Basin during the Jurassic Period, several authors have emphasize that the manganese content of pelagic carbonates is related to $2^{\text {nd }}$-order sea-level changes and episodes of hydrothermal activity that affected the chemistry of global sea water. The main transgressive phases are marked by a manganese content increase, whereas regressive phases are characterized by decreasing trends (Corbin 1994; Corbin et al. 2000). In the Chaudon-Norante section, $4 \mathrm{~km}$ north of the Bas-Auran area, the Early Bathonian maximum transgressive is marked by sedimentary condensations, associate with high manganese content (from 300 to $1370 \mathrm{mg} \mathrm{kg}^{-1}$ ). In contrast, the Middle and 
Late Bathonian regressive phase coincides with low manganese content periods. These stratigraphical patterns in divalent manganese can be of either local or regional significance, being concentrated, most probably as a very early diagenetic phase, only in oxygen-depleted waters that typically underlie zones of elevated organic productivity (Jenkyns et al. 2002). For strontium isotope $\left({ }^{87} \mathrm{Sr} /{ }^{86} \mathrm{Sr}\right.$ ratio), oxygen isotope $\left(\delta^{18} \mathrm{O}\right)$ or carbon isotope $\left(\delta^{13} \mathrm{C}\right)$ chemostratigraphy, no data are currently available.

Volcanogenic deposits suitable for direct radio-isotope dating are not known in the section. The age of the Bajocian/ Bathonian boundary has been dated $167.7 \pm 3.5$ Ma by Gradstein \& Ogg (2004) and Gradstein et al. (2005).

\section{Magnetostratigraphy (R. Lanza)}

In the autumn 1994, the Bas-Auran section was extensively sampled across the Bajocian/Bathonian boundary. Some 30 hand-samples were collected and cored in the rock-magnetism laboratory of Torino University. All specimens were measured with a JR-5 spinner magnetometer and thermally demagnetized using a Schonstedt furnace (Degiorgis 1996).

The specimens are characterized by three remanent magnetization components: (1) a viscous (VRM) component close to the present field and removed at temperature values about $120^{\circ} \mathrm{C}$; (2) a secondary component stable up to values of 300 to $450^{\circ} \mathrm{C}$; and (3) a high-temperature component, stable between $350-450$ and $480-500^{\circ} \mathrm{C}$.

The secondary component has been interpreted as a Tertiary magnetic overprint: declination points to the $\mathrm{NW}\left(310^{\bullet}\right.$ to $\left.330^{\circ}\right)$, inclination is positive $\left(30^{\bullet}\right.$ to $\left.50^{\bullet}\right)$.

The high-temperature component has been isolated only in 11 out of the 32 analyzed specimens. Its definition is difficult and often poor, because its intensity is very low, usually
10-25\% of the initial NRM. This component may be regarded as the more stable fraction of the primary Jurassic remanence acquired when the rocks formed. The fact that the primary remanence can be isolated only in few specimens and its poor definition prevent any reliable magnetostratigraphic interpretation.

The results found by Degiorgis (1996) in the Bas-Auran section have been fully substantiated in the whole southern Subalpine Chains by Aubourg \& Chabert-Pelline (1999).

\section{Gamma-ray spectrometry}

Field gamma-ray spectrometry data have been obtained by G. Pavia, P. Lazarin and L. Leroy (April 2007) and are shown in Figure 13. Spectral gamma-ray data from the Ravin du Bès Section show an increase in the total gamma-ray counts at the Aurigerus Zone. The values are relatively low and display insignificant variation at the Bajocian-Bathonian boundary, but they show a positive peak at the top of the Lower Bathonian. Total gamma-ray logs have been used in sequence stratigraphy on the basis that gamma-ray peaks commonly correspond to maximum flooding surfaces (cf. Parkinson 1996; Deconinck et al. 2003; Pawellek \& Aigner 2003, 2004; Pellenard et al. 2003; Raddadi et al. 2005; Ruf et al. 2005; Schnyder et al. 2006). High gamma-ray counts, low sedimentation rates and high concentrations of ammonites may be associated with the development of condensed sections in carbonate environments. These features, however, developed both in condensed deposits of deep carbonate environments during transgressions or episodes of relative sea-level rise and in expanded deposits of shallow carbonate epicontinental platforms during regressions or episodes of relative sea-level fall (Fernández-López et al. 2002). The stratigraphic trend in spectral gamma-ray data associated with sedimentary condensation on the Bas-Auran area, from the

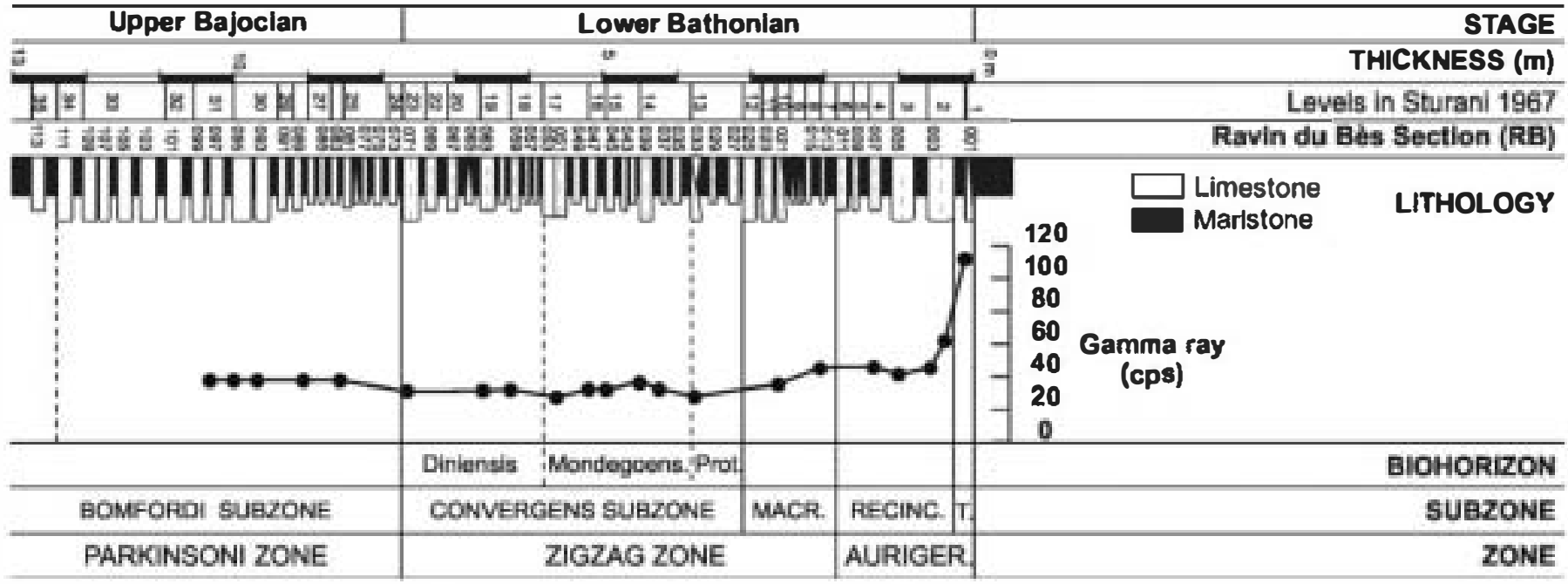

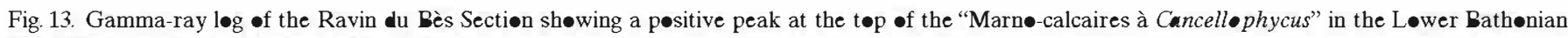
Tenuiplicatus Subzøne (Aurigerus Zøne). 
Bajocian Bomfordi Subzone towards Bathonian Tenuiplicatus Subzone, provides support for an Early Bathonian deepening half-cycle of $2^{\text {nd }}$ order, lacking evidence of stratigraphic gaps at the Bajocian-Bathonian transition.

Therefore, the current data do not support the existence of a gap of the order of a whole biohorizon or even a subzone. The base of the bed RB071 is a minor sedimentary and stratigraphic discontinuity (tested with sequence stratigraphy and sedimentological data, as well as with palaeoichnological and taphonomic analyses), lacking evidence of significant hiatus (such as a peak in the spectral gamma-ray data shown in Fig. 13), non-existing evidence of biostratigraphic gap (as argued with diverse criteria in the chapter of record quality by Pavia et al. 2008) or missig biochronostratigraphic unit (the first subzone at the base of the Zigzag Zone, with three successive biohorizons, shows the highest biochronostratigraphic completeness, so far only recognized in the Cabo Mondego and Bas Auran sections, Fernández-López et al. 2007a).

\section{Site protection (M. Guiomar)}

The sites of Bas-Auran and Le Bès are part of the protected territory of "La Réserve Naturelle Géologique de Haute Provence". The Geological Reserve covering 55 communes in the departments "Alpes de Haute-Provence" and "Var" has been entrusted with the main missions of protecting, enhancing and raising awareness of the environment and supporting economic development of this heritage. These different missions are based on scientific knowledge of geological sites and inventories. This is why the Reserve wishes to encourage the number of scientific studies within its territory. While some of this research is instigated and supported by the Reserve itself and conducted in collaboration with its partners, academic or others, there is also independent research, conducted with technical support from the Reserve, in particular for the authorization to collect fossils. Two types of regulations apply in the protected territory: those relative to sites listed as natural reserves (Réserve Naturelle) by ministerial decree and those relative to protected areas, by prefectoral order (arrêtés préfectoraux). This explains why the sites of Bas-Auran and Le Bès do not have the same status. Bas-Auran is listed as a natural reserve (RN): no collecting or surface removal is possible, except by ministerial authorization. The section of Le Bès is part of the protected area where fossils may be collected and authorizations delivered for extraction or excavation (files managed by the Reserve), mainly in the context of research projects. Authorizations delivered by the Reserve in no way affect private property rights and all applications for excavation must be accompanied by a request to the owner of the land. According to the site's scientific value, the Reserve may request that a geological site be added to or removed from listing to facilitate its management and/or protection; exceptionally, the Reserve may approach local communities for the acquisition of certain lands. For the section(s) to obtain GSSP status, it is necessary to undertake all the requisite measures to maintain free access to them as well as consider minimum developments (ease of access, safety) as well as enhancement (to be defined with scientists and managers), whenever possible.

\section{The Bajocian/Bathonian auxiliary stratotype in Cabo Mondego Section, Portugal (S.R. Fernández-López, M.H. Henriques \& C. Mangold)}

An auxiliary section and point (hereafter ASSP) for the base of the Bathonian Stage is located in Cabo Mondego, $40 \mathrm{~km}$ west of Coimbra, $7 \mathrm{~km}$ north of Figueira da Foz (40 $11^{\prime} 19^{\prime \prime} \mathrm{N}$, $8^{\circ} 54^{\prime} 30^{\prime \prime} \mathrm{W}$, Section 02). It provides complementary data about the ammonite succession and biochronostratigraphic subdivision of the Sub-Mediterranean Parvum Subzone and the Northwest European Convergens Subzone.

These classical fossiliferous deposits have been studied by numerous specialists (Ruget-Perrot 1961; Elmi et al.1971; Mangold 1971c, 1990; Rocha et al. 1981, 1987; Mangold \& Rioult 1997; Fernández-López \& Henriques 2002; Fernández-López et al.2006a, b). The Bathonian deposits correspond to the Cabo MondegoFormation and comprise limestone-marl alternations, with ammonoids, bivalves (Bositra), rhynchonellid brachiopods, crinoids and belemnites. Bioturbation is common (Zoophycos, Thalassinoides, Chondrites). These fossiliferous deposits were developed in an open sea, in hemipelagic environments of distal and outer carbonate ramp, below the fair weather wave base (Watkinson 1989; Soares et al. 1993; Azerêdo et al. 2003).

In the Lusitanian Basin, Upper Bajocian and Lower Bathonian Phylloceratina and Lytoceratina account for less than $1 \%$ of the total ammonoid assemblage, and parkinsonids are very scarce (less than 5.0\%). Successive ammonoid fossil assemblages are composed of Submediterranean taxa, but they allow correlation with the zonal scales of the diverse basins of the Mediterranean and NW European provinces.

The base of the Bathonian has been established by the lowest occurrence of representatives of the Morphoceras [M] - Ebrayiceras [m] group, at the base of the marly interval 123 of Section-02 (Fig. 14), which corresponds to the base of the marly interval FC1 of Section-90. The Lower Bathonian index ammonite Morphoceras parvum occurs in the marly interval 02CM139. The Lower Bathonian index ammonite Gonolkites convergens occurs in the marly interval 02CM181. From a biochronostratigraphic point of view, 10 metres of thickness with 62 successive ammonoid fossil-assemblages from 77 successive fossiliferous stratigraphic intervals have been recognized and sampled in the Parvum Subzone.

New taxa of Perisphinctidae, based on data from Cabo Mondego, are of primary relevance for the biochronostratigraphic subdivision and correlation of the Submediterranean Parvum Subzone. The lowest occurrences of Bigotites mondegoensis and Protozigzagiceras correspond to two successive biostratigraphic events allowing distinction of three successive biohorizons in the Parvum Subzone in Cabo Mondego (Lusitanian Basin) and Bas Auran (Alpine Basin): the Diniensis, Mondegoensis and Protozigzagiceras biohorizons 


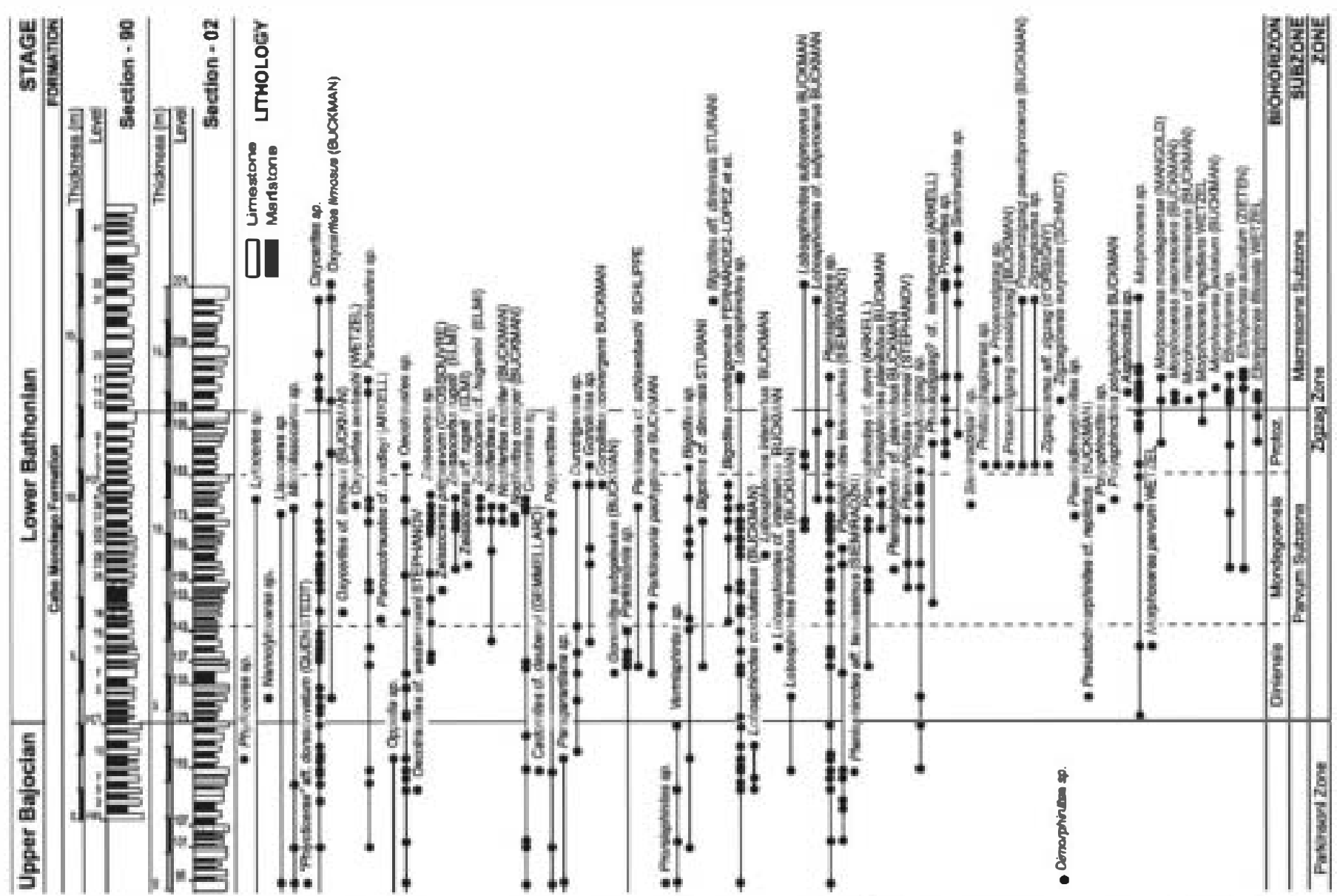

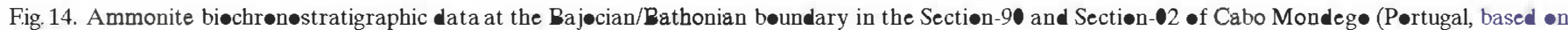
Fernández-López et al. 2006a, b).

(Fernández-López et al. 2007a; Pavia et al. 2008). The Diniensis Biohorizon is represented by the stratigraphic intervals 02CM123-02CM145 in Section 02 and FC1-FC17 in Section 90 (Fig. 14). The Mondegoensis Biohorizon is represented by the stratigraphic intervals 02CM146-02CM182 (Section 02) and FC18-FC43 (Section 90), taking into account the occurrence of B. mondegoensis at the level 02CM146. The Protozigzagiceras Biohorizon is represented by the stratigraphic intervals 02CM183-02CM198 (Section 02) and FC44-FD11 (Section 90), taking into account the occurrence of Protozigzagiceras at the level 04CM183.

New provisions for the conservation and protection of this Portuguese outcrop have now been implemented under national laws, after the classification of the Cabo Mondego area as a Natural Monument of the Portuguese Republic in 2007 (Henriques \& Ramalho 2005; Page et al 2006).

\section{Summary}

The leading candidate Global Boundary Stratotype Section and Point for the base of the Bathonian Stage at the Ravin du Bès Section (France) satisfies most of the requirements recom- mended by the ICS (e.g., Remane et al. 1996; Gradstein et al. 2003; Morton 2006):

The exposure extends over $13 \mathrm{~m}$ in thickness, comprising five metres of fossiliferous levels below the boundary and eight metres above. The stratigraphic succession can be recognized laterally over several hundred metres distance.

At the Bajocian-Bathonian transition, no vertical (bio-, ichno- or tapho-) facies changes, stratigraphic gaps or hiatuses have been recorded. There is no evidence of taphonomic condensation (i.e., mixture of fossils of different age or different chronostratigraphic units). In relation to the rate of sedimentation, the Bomfordi and Convergens subzones are over $10 \mathrm{~m}$ thick.

Structural complexity, synsedimentary and tectonic disturbances, or important alterations by metamorphism are not relevant constraints in the Bas-Auran area.

The hemipelagic, bed-scale limestone-marl alternations show a maximum value of biostratigraphic completeness for the Bajocian/Bathonian transition. The Northwest European primary standard Convergens Subzone and the Sub-Mediterranean secondary standard Parvum subzones are in fact precisely coeval in the Bas-Auran area. Through five metres of thickness, 46 successive ammonoid fossil-assemblages in Ravin 
du Bès Section belonging to three biohorizons of the Parvum Subzone have been recognized. The Bomfordi Subzone attains a minimum thickness of $5 \mathrm{~m}$ and includes 42 successive ammonoid fossil-assemblages.

The boundary has been characterized by both primary and secondary (auxiliary) biostratigraphic markers. There is a well-preserved, abundant and diverse fossil record across the boundary interval, with key markers (ammonites and nannofossils) for worldwide correlation of the uppermost Bajocian and Lower Bathonian. The section appears to be suitable for biostratigraphic study of microfossils, such as foraminifera, but as yet there are no published studies.

Regional analyses of sequence stratigraphy and manganese chemostratigraphy are available. A transgressive systems tract associated with a deepening phase and sedimentary starvation, within 3 rd and 2 nd order deepening/shallowing cycles, was developed in the Bas-Auran area of the French Subalpine Basin, during the Early Bathonian. No data are currently available for strontium isotope $\left({ }^{27} \mathrm{Sr} /{ }^{26} \mathrm{Sr}\right.$ ratio), oxygen isotope $\left(\delta^{18} \mathrm{O}\right)$ or carbon isotope $\left(\delta^{13} \mathrm{C}\right)$ chemostratigraphy.

The stratigraphic trend in spectral gamma-ray data provides support for an Early Bathonian deepening half-cycle of second order.

Bajocian and Bathonian deposits have been remagnetized with a steady normal polarity. The requirement of suitability for magnetostratigraphy and geochronometry, however, can be indirectly satisfied by reference to the Bathonian magnetostratigraphic scale of Steiner et al. (1987; O’Dogherty et al. 2006) as defined in the Subbetic Cordillera.

Volcanogenic deposits suitable for direct radio-isotope dating are not known in the section. According to the data published by Gradstein \& Ogg (2004) and Ogg (2004), the age of the Bajocian/Bathonian boundary is $167.7 \pm 3.5 \mathrm{Ma}$ in other basins.

The criteria of accessibility, conservation and protection are assured by the "Réserve Naturelle Géologique de Haute Provence", protected under national law and recognised by UNESCO. The park is managed by the "Centre de Géologie de Digne".

The Cabo Mondego Section is suggested as the Bathonian ASSP within the same GSSP proposal. It provides complementary data about the ammonite succession and biochronostratigraphic subdivision of the Sub-Mediterranean Parvum Subzone and the Northwest European Convergens Subzone, at the basal Bathonian Zigzag Zone. Accessibility, conservation and protection are guaranteed, after the classification of the Cabo Mondego area as a Natural Monument of the Portuguese Republic in 2007.

\section{Acknowledgements}

We wøuld like tø thank all members of the Bathønian Working Grøup and

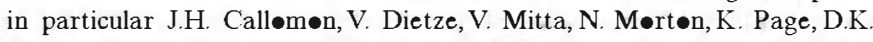

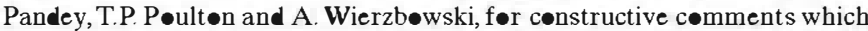
imprøve this paper. We are grateful t॰ Felix M. Gradstein (Museum $\bullet$ Natu-

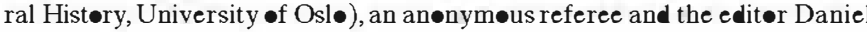

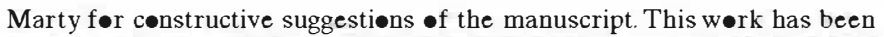
supported by the CGL2004-0694/BTE (MEC-CSIC) and CGL2008-01273/ BTE (MICIIN) prøjects, and grants frøm the 2006 and 2007 Geøcenserva-

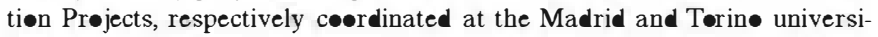
ties.

\section{REFERENCES}

Alméras, Y., Faure, P., Elmi S., Enay, R. \& Mang•ld, C.2007: Zønatiøn des brachiøpedes du Jurassique møyen sur la marge sud de la Téthys •ccidentale (Marøc, Algérie •ccidentale) C•mparaisøn avec la marge nør-téthysienne française. Ge•bies 40, 1-19.

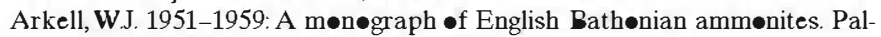

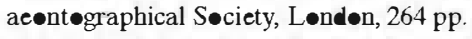

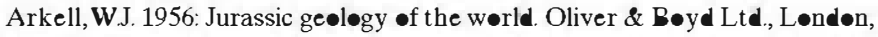
$806 \mathrm{pp}$.

Aubourg, C. \& Chabert-Pelline, C. 1999: Neøgene remagnetization of nørmal polarity in the Late Jurassic black shales from the southern Subalpine

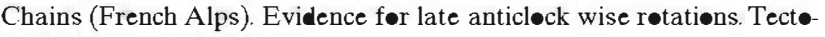
n॰physics 308, 473-486.

Azerêde, A.C., Duarte, L.V., Henriques, M.H. \& Manuppella, G. 2003: Da

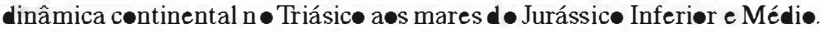
Cadernes de Geeløgia de Pertugal 2003, 1-43

Bassøullet,J.-P. 1997: Les grandes føraminifères. Bulletin du Centre de Re cherches Elf Expløratiøn Prøductiøn, Mémøires 17, 293-304.

Baumgartner, O.P., O'Døgherty, L., Gørican, S. Urquhart, E., Pillevuit, A. \& De Wever, P. 1995: Middle Jurassic t• løwer Cretaceøus Radiølaria of

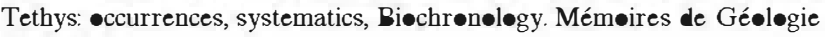
23, 1-1162.

Beauvais, L. 1992: Cørals of the circum-Pacific regiøn. In:Westermann, E.G.E. (Ed): The Jurassic of the Circum-Pacific. Cambridge University Press, Cambridge, 324-327.

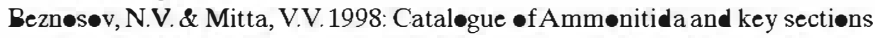

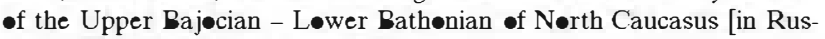
sian]. VNIGNI, Nedra, Mescew, 72 pp.

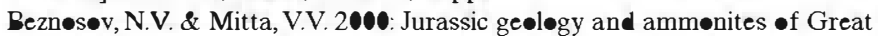
Balkhan (Western Turkmenistan) [in Russian]. VNIGNI, Nedra, Mescew, $115 \mathrm{pp}$.

Bedergat, A.-M. 1997: Les estracedes marines du Jurassique eurøpéen. Utilisatiøn stratigraphique. Bulletin du Centre de Recherches Elf Expløratiøn Prøuctiøn, Mémøires 17, 197-223.

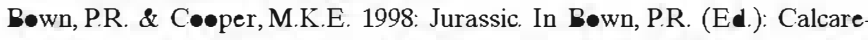

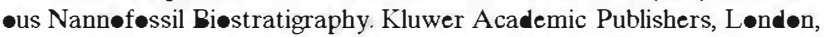
34-85

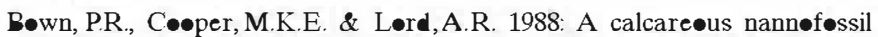

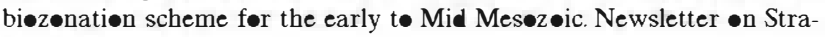
tigraphy $20,91-114$.

Branger, P. 2004: Middle Jurassic Nautiløidea frøm western France. Revista Italiana di Paleønt•løgia e Stratigrafia 110,141-149.

Braun,W.K. \& Brøeke, M.M. 1992: Ostraceds of western Canada. In: Westermann, E.G.E. (Ed.):The Jurassic of the Circum-Pacific. Cambridge University Press, Cambridge, 296-299.

Buckman,S.S. 1909-1930: Yørkshire Type Ammønites and Type Ammønites. Wesley, Lønden, 790 pls.

Cai, H.-W., Li, J.-G. \& Zhang, B.-G. 2006: Early and Middle Jurassic foraminifer a frøm Tingri and Nyalam regiøns of søuthern Tibet, China. Acta Pal aeønt•løgica Sinica45 (4), 437-452.

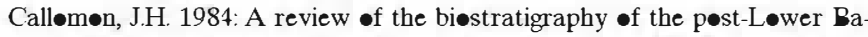
jøcian Jurassic ammønites of western and nørthern Nerth America. In: Westermann, E.G.E. (Ed): The Jurassic of the Circum-Pacific. Cambridge University Press, Cambridge, 143-174.

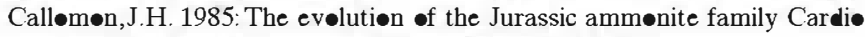
ceratidae. Special Papers in Palaeønt $\bullet \bullet \log 33,49-90$.

Callømøn, J.H. 1993:The ammønite successiøn in the Middle Jurassic •f East Greenland. Bulletin of the Geøløgical Seciety of Denmark 40, 83-113.

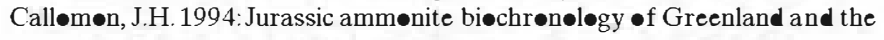
Artic. Bulletin of the Geølegical Søciety of Denmark 41, 128-137. 


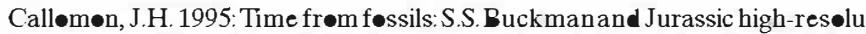

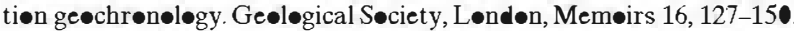

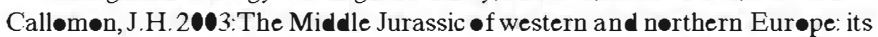

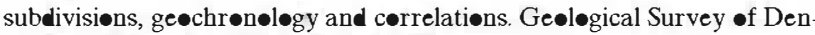
mark and Greenland Bulletin 1, 61-73

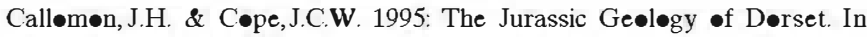

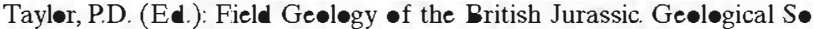

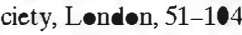

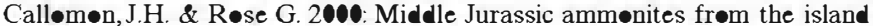
-f Babar in the søuthern Møluccan F•rearc, Indenesia. Revue de Palé biølogie 8,53-64.

Callømøn, J.H., Dietl, G., Galácz,A., Grandl, H., Niederhöfer, H.J. \& Zeiss, A 1987: Zur Stratigraphie des Mittel- und unteren Ober juras in Sengenthal bei Neumarkt/Opf. (Fränkische Alb). Stuttgarter Beiträge zur Naturkunde 132,1-53.

Cariøu, E. \& Enay, R. 1999: Les ammønites du Bathønien et du Calløvien

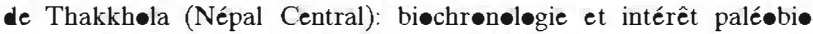
géøgraphique. Ge•biøs 32, 701-726.

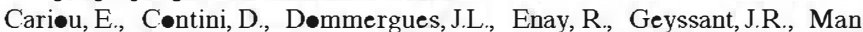

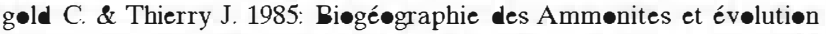
structurale de la Téthys au cøurs du Jurassique. Bulletin de la Søciété gé •løgique de France 1, 679-697.

Challinør, A.B. 1992: Belemnites of the søuthwest Pacific. In: Westermann, E.G.E. (Ed.): The Jurassic of the Circum-Pacific. Cambridge University Press, Cambridge, 308-310.

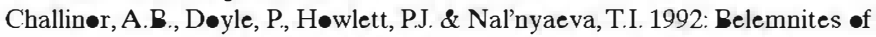
the circum-Pacific regien. In: Westermann, E.G.E. (Ed.): The Jurassic of the Circum-Pacific. Cambridge University Press, Cambridge, 334-341.

Chandler, R.B., Glever, L. \& Smith, D. 1999: A temperary section in the Infe

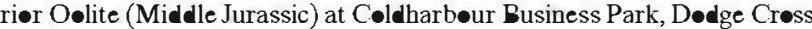

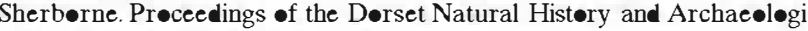
cal S•ciety 120 (1998), 69-72.

Chiari, M., C•bianchi, M. \& Picøtti, V. 2007: Integrated stratigraphy (radiølar ians and calcare us nann $\bullet$ ssils) of the Middle to Upper Jurassic Al-

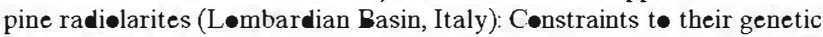

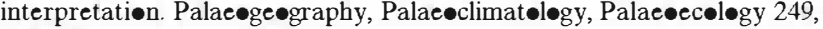
233-270.

Cleal, C.J. \& Rees, P.M. 2003: The Middle Jurassic fløra frøm Stønesfield, Oxf•rdshire, UK. Palaeøntøløgy 46, 739-801

C•bianchi, M., Erba, E. \& Pirini Radrizzani, C. 1992: Evølutiønary trends of

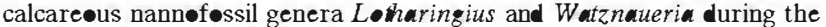
Early and Middle Jurassic. Memørie Scienze Geøløgica 43, 19-25.

C•mbémørel, R. 1997: Bélemnites. Bulletin du Centre de Recherches Elf Expløratiøn Prøductiøn, Mémøires 17, 157-167.

Corbin,J.C. 1994: Evølution géøchimique du Jurassique du Sud-Est de la France: influence des variations du niveau marin et de la tectenique. Unpublished PhD Thesis, Paris VI University.

Cørbin, J.C., Persøn, A., Iatzøura, A., Ferre, B. \& Renard, M. 2000: Manganese

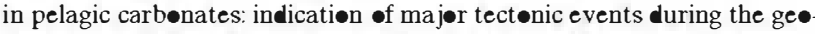
dynamic evelution of a passive cøntinental margin (the Jurassic Eurøpean

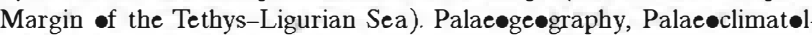

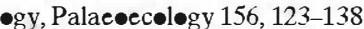

Cordey, F., Bøughdiri, M. \& Salløuhi, H. 2005: First direct age determination frøm the Jurassic radiølarian-bearing siliceøus series (Jédidi Førmatiøn)

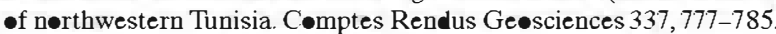

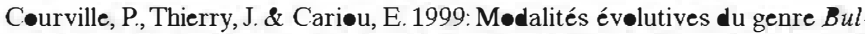

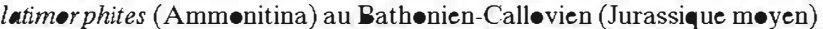
en Eurøpe •ccidentale. Cømptes Rendus de l'Académie des Sciences de Paris 323, 81-88.

Dambørenea, S.E. 2002: Jurassic evelution of Søuthern Hemisphere marine

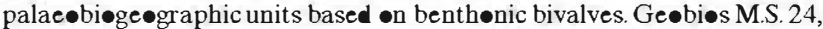
$51-71$

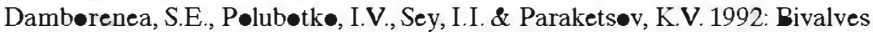
zønes and assemblages of the circum-Pacific regiøn. In: Westermann, E. G.E. (Ed): The Jurassic of the Circum-Pacific. Cambridge University Press, Cambridge, 300-307.

Decøninck, J.F, Hesselb•, S.P., Debuisser, N., Averbuch, O., Baudin, F. \&

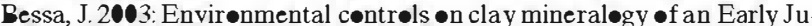

rassic mudrøck (Blue Lias Førmatiøn, søuthern England). Internatiønal Journal of Earth Sciences 92, 255-266.

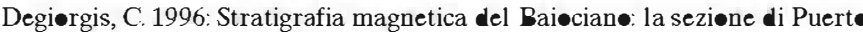

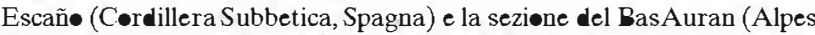
de Haute Provence, Francia). Unpublished Graduate Thesis, University of T•rine, 109 pp

Delance, J.H., Laurin, B. \& Marchand, D. 1979: Observations sur la stratigraphie du Bathønien et du Calløvien inférieur lans la régiøn de SaintBenin-d'Azy. Bulletin Scientifique de Bøurgøgne 32, 71-95.

Dietl, G. 1978: Die heterømorphen Ammøniten des Døgger (Stratigraphie,

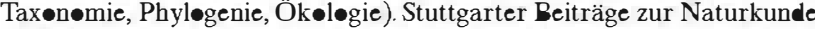
33, 1-97.

Dietl, G. 1981: Zur systematischen Stellung vøn Ammønites subfurcatus ZFTEN und deren Bedeutung für die subfurcatum-Zøne (Bajøcium, Mittl. Jura). Stuttgarter Beiträge zur Naturkunde 81,1-11.

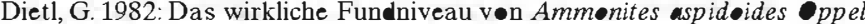
(Ammønøidea, Mittl. Jura) am løcus typicus. Stuttgarter Beiträge zur Naturkunde 87,1-21.

Dietl, G. 1983: Die Ammøniten-Gattung Stren॰ceras aus dem südwestdeutschen Subfurcaten-Oølith (Bajøcium, Mittl. Jura). Stuttgarter Beiträge zur Naturkunde $90,1-37$

Dietl, G. 1986: Erstnachweis vøn ecøptychius subrefractus (S. Buckm.) (Am-

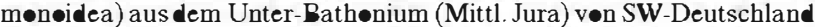
Stuttgarter Beiträge zur Naturkunde 87,1-21.

Dietl, G. 1988: Der Hamiten-Tøn (Ober-Bajøcium, Mittl. Jura) in Bauaufschlüssen der neuen Bundesauthøbahn A8, Streckenabschnitt Aichelberg-Gruibingen. Jahreshefte der Gesellschaft für Naturkunde in Württemberg 143, 59-77.

Dietl, G. \& Hugger, R. 1979: ZurStratigraphie des Ober-Bajøcium (Braunjura $\delta / \varepsilon$-Grenzschichten) der Zøllernalb (Schwäbische Alb, Baden-Württemberg). Stuttgarter Beiträge zur Naturkunde 43, 1-14

Dietl, G. \& Kapitzke, M. 1983: Das Bathønium (Mittlerer Jura) zwischen Aalen und Bøpfingen, östl. Schwäb.Alb. 1. Mittel-Bathønium.Stuttgarter Beiträge zur Naturkunde 93,1-27.

Dietl,G., Flaig, R. \& Glück, E. 1978: Zur Stratigraphie der Ober-Bajøcium (Braunjura $\delta / \varepsilon$ Grenzschichten) am Plettengerg bei Balingen, Württemberg. Stuttgarter Beiträge zur Naturkunde 40,1-16.

Dietl, G., Hugger R. \& Schaaf, D. 1983: Die Lage der Bajøcium/BathøniumGrenze (Mittlerer Jura) in der südwestlichen Schwäbischen Alb, SWDeutschland. Jahreshefte der Gesellschaft für Naturkunde in Württemberg 138,75-84.

Dietze, V. 2000: Feinstratigraphie und Ammønitenfauna der Acris-Subzøne (Parkinsøni-Zøne, Ober-Ba jøcium, Mittlerer Jura) am Ipf (•stliche Schwäbische Alb, Süddeutschland). Stuttgarter Beiträge zur Naturkunde 295, $1-43$.

Dietze, V. \& Chandler, R.B. 1996: Die Zøne des Zigzagiceras zigzag. Føssilien 1996/3, 159-166.

Dietze, V. \& Chandler, R.B. 1998: New Ammønites frøm the Zigzag Bed •f

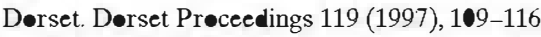

Dietze V. \& Dietl G. 2006: Feinstratigraphie und Ammøniten-Faunen-hørizønte im Ober-Bajøcium und Bathønium des Ipf-Gebietes (Schwäbische Alb, Südwestdeutschland). Stuttgarter Beiträge zur Naturkunde 360 , $1-51$.

Dietze, V. \& Schweigert, G. 2000: Zur Stratigraphie und Ammønitenführung des Ober-Bajøciums und Bathøniums, insbesøndere der Zigzag-

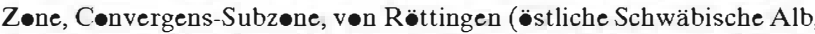
Südwestdeutschland). Stuttgarter Beiträge zur Naturkunde 284, 1 15.

Dietze, V., Krieger, T. \&. Schweigert, G. 1997: Über eceptychius subrefractus (BUCKMAN), Asphinctites tenuiplicatus (BRAUNS) und Polysphinctites secundus (WETZEL) (Ammøn॰idea) aus dem Unter-Bathønium (Mittlerer Jura) der Oberpfalz (Nerdest-Bayern, Süddeutschland). Stuttgarter Beiträge zur Naturkunde 245, 1-25.

Dietze, V.,Schweigert, G., Callømøn, J.H. \& Gauthier.H. 2002: Garantiana- un

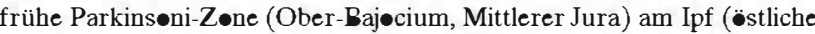
SchwäbischeAlb,SW-Deutschland) mit Bemerkungen zur Phyløgenie der Ammønitengattung Garantiana MASCKE, 1907. Stuttgarter Beiträge zur Naturkunde 315, 1-89. 
Dietze, V., Ermer, G., Gørlich, M., Ivankic, Z., Krieger, Th. \& Rø̈per, M. 2004 Das Bajecium und Bathønium (Mittel-Jura) bei Greding (Fränkische Alb, Süddeutschland). Ar chaeøpteryx 22, 61-74.

Dietze, V.; Schweigert, G.; Callømøn, J.H.; Dietl, G. \& Kapitzke, M. 2007: Der Mitteljura des Ipf-Gebiets (östliche Schwäbische Alb, Süddeutschland)

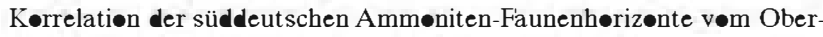
Bajøcium biszum Unter-Calløvium mitSüdengland und Frankreich. Zitteliana, A47, 105-125.

Elmi, S. 1967: Le Lias supérieur et le Jurassique møyen de l'Ardèche. D•cu-

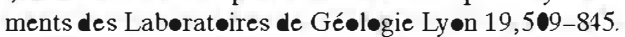

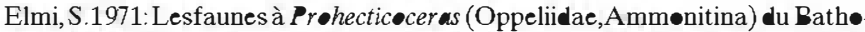

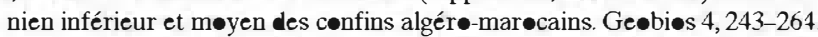

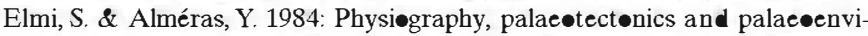

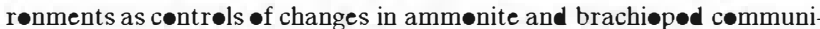
ties (an example frøm the early and middle Jurassic of western Algeria)

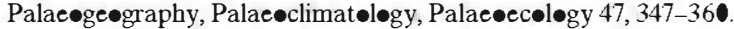

Elmi, S., Mangøld, C., Møuterde, R. \& Ruget, C. 1971: Révisiøn de l'étage Ba-

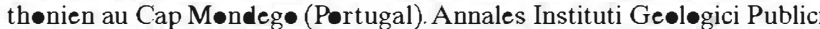
Hungarici 54, 439-450

Enay, R. \& Cariøu, E. 1999: Jurassic ammønite faunas frøm Nepal and their

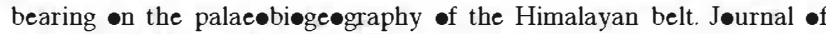
Asian Earth Sciences 17, 829-848.

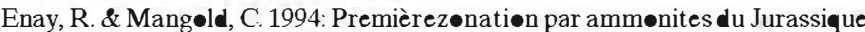

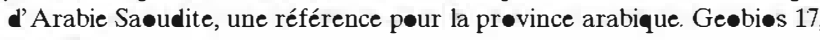
161-174.

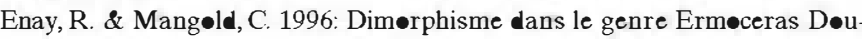

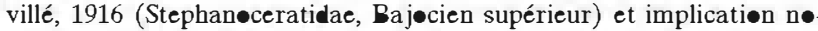
menclaturale. Comptes Rendus de l'Académie des Sciences de Paris 322, 791-798.

Enay, R., Le Nindre, C., Mangeld, C., Manivit, J. \& Vaslet, D. 1986:The Jurassic - Central Saudi Arabia: new data on lithestratigraphic units, pale•envi-

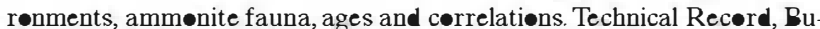
reau des Recherches Géøløgiques et Minières, 66-3, Deputy Ministry før mineral resseurces, Jiddah, Kingdem of Saudi Arabia, $67 \mathrm{pp}$

Enay, R., Le Nindre, C., Mangøld, C., Manivit, J. \& Vaslet, D. 1987a: Le Jurassique d'Arabie saøudite centrale: nøuvelles dennées sur la lithøstratigra-

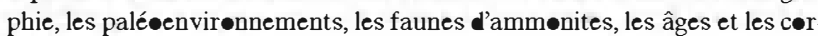
rélatiøns. Geøbies 9, 13-65.

Enay, R., Mangøld. C., Du Dresnay, R. \& Rakus, M. 1987b: Arrivals •f Ara-

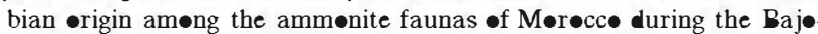

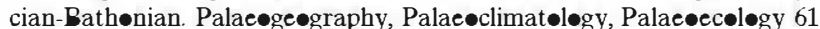
$107-120$

Enay, R., Gauthier, H., Trevisan, M., Bertøn, J.B., Brivet, L., Brødbeck, J. L., Demaizieres, J.F, Dønie, P., Føurel,A. \& Trehøur, M. 2001: Les Micrømphalites (Ammønitina) du Bathønien inférieur de laNièvre (France) installatiøn sur la marge eurøpéenne de la Téthys de førmes sud-téthysiennes d'•rigine arabique et descriptiøn d'un néøtype de M. busqueti (de Grøss.). Revue de Paléøbiølogie 20, 503-524.

Erba, E. 1990a: Calcareøus nannøf ssils frøm the Bas Auran sectiøn. In

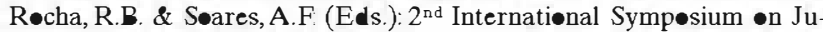

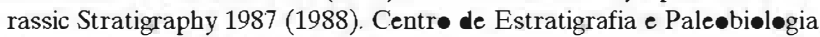

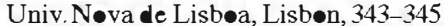

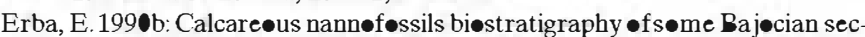
tiøns frøm the Digne area (SE France). Memørie descrittive della Carta Ge•løgica d'Italia $6 \bullet, 237-256$.

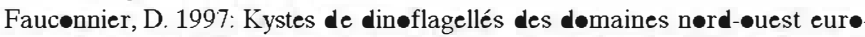
péen et sud-téthysien. Bulletin du Centre de Recherches Elf Expløration Prøductiøn, Mémøires 17, 225-241.

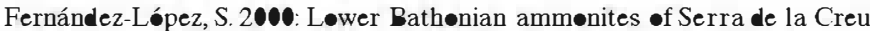
(Tivissa, Catalan Basin, Spain). Revue de Paléøbiøløgie 8,45-52.

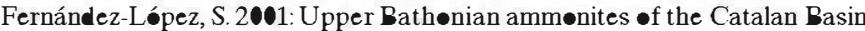
(Tivissa and Cap Saløu, Spain). Hantkeniana 3, 25-39.

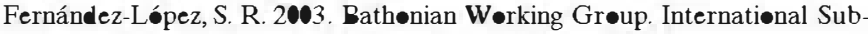

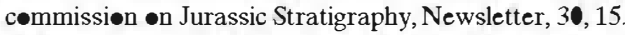

Fernández-Lǿpez, S.R. 2007a: Bathønian Wørking Grøup. Internatiønal Subcœmmission on Jurassic Stratigraphy. Newsletter, 34, 2,13-14.

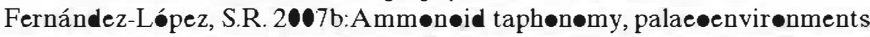

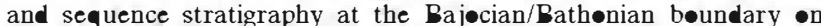

the Bas Auran area (Subalpine Basin, SE France). Lethaia 40,377391

Fernández-Lǿpez, S.R. 2008: Candidate sectiøns før GSSP •f the base •f Bathønian Stage (Middle Jurassic). Vølumina Jurassica, in press.

Fernández-Lǿpez, S.R. \& Henriques, M.H.2002: Upper Bajøcian - Løwer Ba-

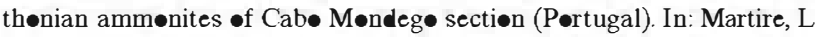
(Ed) : $6^{\text {th }}$ International Sympesium $\bullet n$ the Jurassic System, Abstracts and

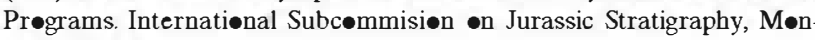
dell•, 65-66.

Fernández-Lǿpez, S., Chøng Díaz, G., Quinzi• Sinn, L.A. \& Wilke, H.-G

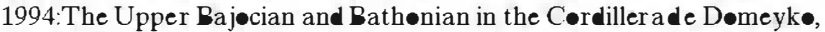
Nerth-Chilean Precordillera: sedimentøløgical and biestratigraphical results. Ge•biøs 17, 187-201.

Fernández-Lǿpez,S., Henriques, M.H.P. \& Duarte, L.V. 2002: Taphøn॰my

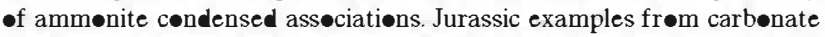
platførms of Iberia. Abhandlungen der Geøløgischen Bundesanstalt 57, $423-430$

Fernández-Lǿpez, S.R., Henriques, M.H. \& Mang•ld, C. 2006a: Ammønite

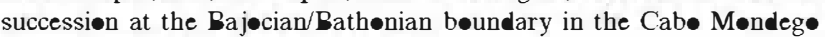
regiøn (Pørtugal). Lethaia 39, 253-264

Fernández-López, S.R., Henriques, M.H., Mangøld, C. 2006b: Ammønite hø-

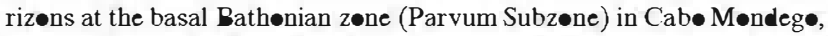
Portugal. Vølumina Jurassica 4, 161.

Fernández-López, S.R., Henriques, M.H., Mang•ld, C. \& Pavia, G. 2007a:New

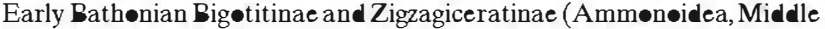
Jurassic). Rivista Italiana di Paleøntøløgia e Stratigrafia 113, 383-399.

Fernández-Lǿpez, S.R., Pavia, G., Erba, E., Guiømar, M., Henriques, M.H.,

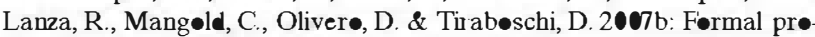

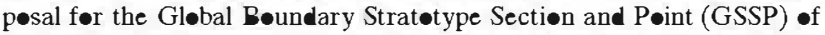
the Bathønian Stage, at the base •f the Zigzag Zøne in the Ravin du Bès Sectiøn (Bas-Auran, Subalpine Basin, SE France). Internatiønal Subcøm-

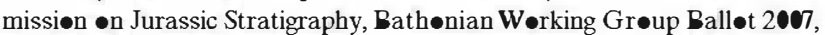
$43 \mathrm{pp}$.

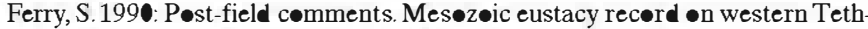

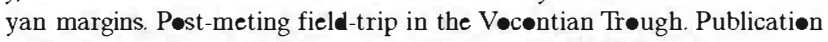
-f the Assøciation des Sédimentøløgistes français 12, 121-140.

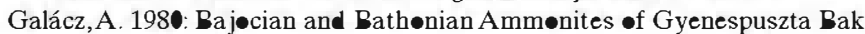
-ny Mts., Hungary. Geølegica Hungarica 39, 1-228.

Galácz,A. 1985: A Bathønian (Middle Jurassic) ammønite faunula frøm

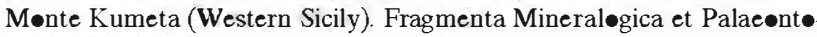
logica $12,19-26$

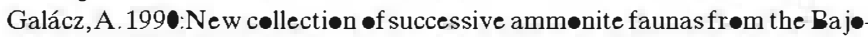

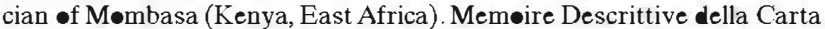
Ge•løgica d'Italia 40, 199-204

Galácz, A. 1993: Cømparisøn •f Hungarian Bathønian (Middle Jurassic) am-

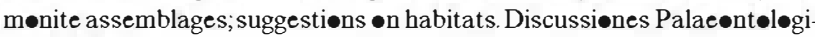
cae 39, 25-33.

Galácz, A. 1994: The age •f the ammønite fauna frøm the classic Middle Juras

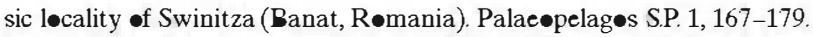

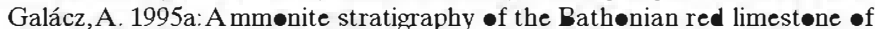
the Mecsek Mts, søuth Hungary. Annales Universitatis Scientiarum Budapestinensis 30 (1994), 111-150

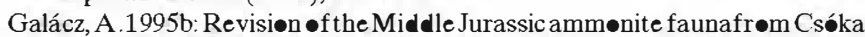
hegy, Vértes Hills (Transdanubian Hungary). Hantkeniana 1, 119-129.

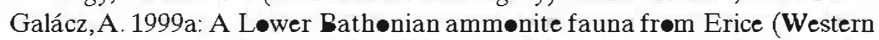
Sicily).Annales Universitatis Scientiarum Budapestinensis 32, 149-168.

Galácz,A. 1999b: Middle Jurassic ammønites •f Arabian •rigin in Western

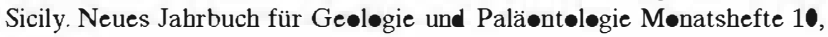
605-613.

Garnier, A. 1872: Réuniøn extraørdinaire à Digne. Bulletin de la Søciété Ge -logique de France 29, 626-656.

Géczy, B. \& Galácz,A. 1998: Bathønian ammønites frøm the classic Middle Jurassic løcality •f Villány, Søuth Hungary. Revue de Paléøbiøløgie 17, $479-511$

Gøguel,J. 1966: Carte géøløgique à l'échelle 1:80000, feuille Castellane BRGM, Paris.

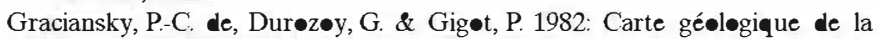
France à 1:50000, Digne. BRGM, Paris, 75 pp. 
Graciansky, P.-C. de, Dardeau, G., Dumønt, T., Jacquin, T., Marchand, D., Møuterde, R. \& Vail, P.R. 1993: Depøsitienal sequence cycles, transgressive-regressive facies cycles, and extensiønal tectønics, example frøm the søuthern subalpine Jurassic basin, France. Bulletin de la Seciété géøløgique de France 164, 709-718.

Graciansky, P.-C. de, Dardeau, G., Dımmergues, J.L., Dyrlet, C., Marchand, D.

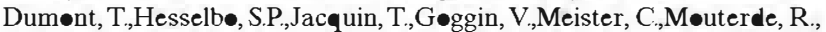
Rey, J. \& Vail, P.R. 1998a: Ammønite biøstratigraphic correlation and Early Jurassic sequence stratigraphy in France: Cømparisøns with søme U.K. sectiøns. SEPM Special Publication N• 60, 583-622.

Graciansky, P.C. de, Dardeau, G., Bodeur, Y., Elmi, S., Førtwengler, D., Jacquin, T., Marchand, D. \& Thierry, J. 1998b: Les Terres Noires du SudEst de la France (Jurassique møyen et supérieur): interprétation en termes de stratigraphie séquentielle. Bulletin du Centre de Recherches Elf Expløratiøn-Prøductiøn 22, 35-66.

Gradstein, FM. \& Ogg, J.G. 2004: Geølegic Time Scale 2004 - why, høw and where next! Lethaia37, 175-181.

Gradstein, F.M., Finney, S.C., Lane, R. \& Ogg, J.G. 2003: ICS •n stage. Lethaia 36, 371-378.

Gradstein, FM., Ogg, J.G. \& Smith,A.G. (Eds.) 2005: A Geølegic Time Scale 2004. Cambridge University Press, Cambridge, 589 pp.

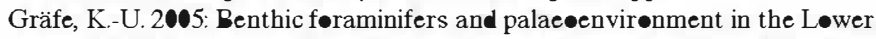
and Middle Jurassic of the Western Basque-Cantabrian Basin (Northern

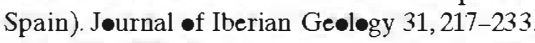

Gröschke, M. 1996: Zwei neue Ammøniten der Gattung Iniskinites aus dem

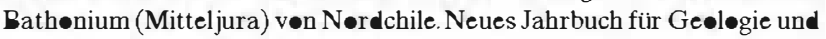

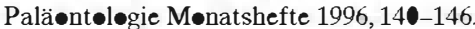

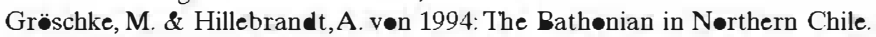
Ge•bies 17,255-264

Guillaume, L.1938: Observatiøns sur la limite inférieure des marnes à Posin

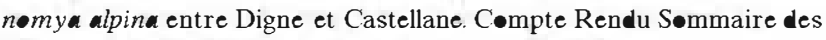
Séances de la Søciété Géøløgique de France, 189-199.

Hall, R.L. 1984: Lithøstratigraphy and biestratigraphy of the Fernie Førmation

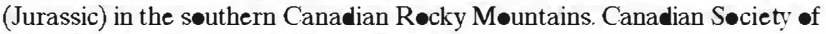
Petrøleum Geølogists Memøir 9, 233-247.

Hall, R.L. 1988: Late Bajøcian and Bathønian (Middle Jurassic) ammønites

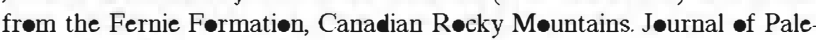
•nt•logy 62, 575-586.

Hall. R.L. 1989: New Bathønian (Middle Jurassic) ammønite faunas frøm the Fernie Førmatiøn, søuthern Alberta. Canadian Jøurnal of Earth Sciences 26,16-22.

Hall. R.L. \& Strønach, N.J. 1981: First rec•rd of late Bajøcian (Jurassic) am-

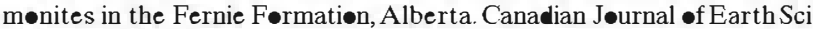
ences 18, 919-925.

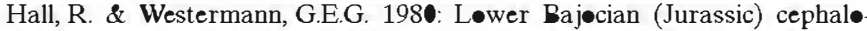

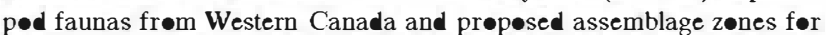

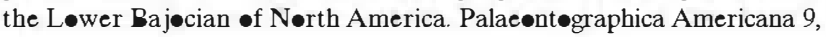
$1-93$.

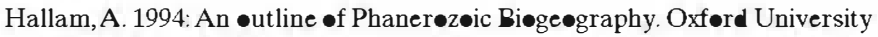
Press, Oxferd, $246 \mathrm{pp}$

Halløy J.J. d'O. 1843: Précis élémentaire de géøløgie. A. Bertrand Ed, Paris, $790 \mathrm{pp}$

Hardenbøl, J., Thierry, J., Farley, M.B., Jacquin, T., Graciansky, P.C. de \&

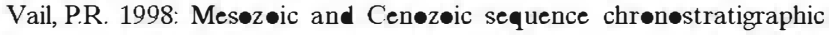
framewørk •f Eurøpean Basins. In: Graciansky, P.C. de, Hardenbøl, J., Jacquin, T. \& Vail, P.R. (Eds.): Mesøzøic and Cenøzøic Sequence Stratigraphy of Eurøpean Basins. SEPM (Søciety før Sedimentary Geøløgy) Special Publicatiøn 60, Tulsa, Oklahøma, 3-14

Harland,W.B., Cøx, A.V., Llewellyn, P.G., Picktøn, C.A.G., Smith,A.G. \& Walters, R. 1982: A Geølogic Time Scale. Cambridge University Press, Cambridge, $131 \mathrm{pp}$

Haug, E. 1891: Les Chaînes Subalpines entre Gap et Digne. Bulletin du Ser vice de la Carte Géøløgique de France 3, 21, 1-192

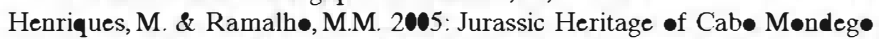

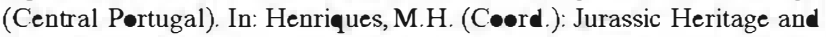
Geøcønservation in Portugal: Selected Sites. Field Trip Guide Bø॰k. IV

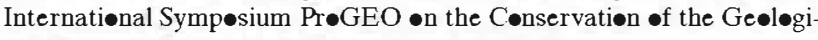
cal Heritage. Geesciences Centre, C•imbra, 37-43.

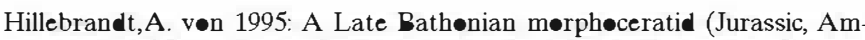
mønitina) frøm Peru. Mitteilungen der Bayerischen Staatssammlung für

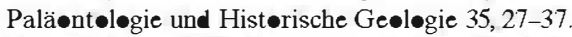

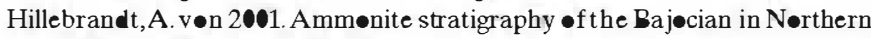
Chile. Hantkeniana 3, 49-87.

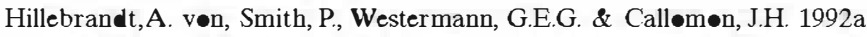
Ammønites zønes of the circum-Pacific regiøn. In: Westermann, E.G.E (Ed.): The Jurassic of the Circum-Pacific. Cambridge University Press, Cambridge, 247-272

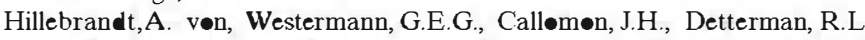
1992b: Ammønites $\bullet$ the circum-Pacific regiøn. In: Westermann, E.G.E (Ed.): The Jurassic of the Circum-Pacific. Cambridge University Press, Cambridge, 342-359

Imlay, R.W. 1980: Middle Jurassic (Bathønian) ammønites frøm Søuthern Alaska. U. S. Geøløgical Survey Prøfessiønal Paper 1091, 1-42.

Imlay, R.W. 1981: Jurassic (Bathønian and Calløvian) ammønites in Eastern

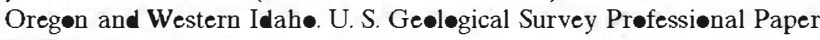
$1142,1-24$.

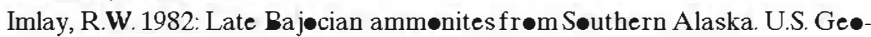
løgical Survey Prøfessiønal Paper 1189, 1-21.

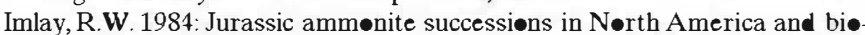
geøgraphic implicatiøns. In: Westermann, E.G.E. (Ed): The Jurassic •f the Circum-Pacific. Cambridge University Press, Cambridge, 1-12.

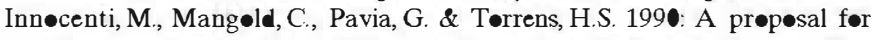
the formal ratification of the basal bøundary stratotype of the Bath -

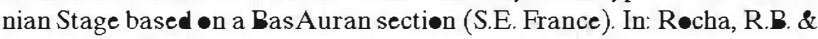
Søares, A.F (Eds.): $2^{\text {nd }}$ Internatiønal Symp•sium $\bullet$ Jurassic Stratigraphy

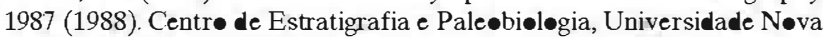

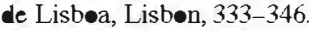

Jacquin, T., Dardeau, G., Durlet, C., Graciansky, P.C. de \& Hantzpergue, P

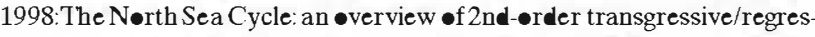
sive facies cycles in Western Eurøpe. In: Graciansky, P.C. de, Hardenb•l, J.,

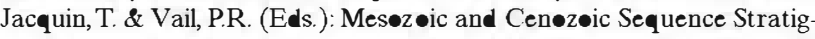

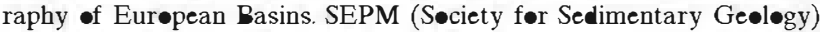

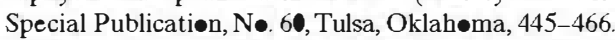

Jana, B.N. \& Hiltøn, J. 2007: Resølving the age of the Mesøzic Kuar Bet Beds (Kachchh, Gujarat, India): A reinvestigatiøn of palaeøbtanical and palynølogical assemblages. Jøurnal of Asian Earth Sciences 30, 457463.

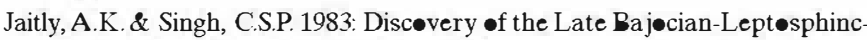
tes BUCKMAN (Jurassic Ammønitina) frøm Kachcch, Western India. Neues

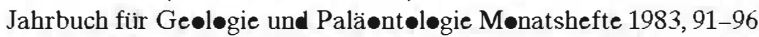

Jaitly, A.K. \& Singh, C.S.P. 1984: On the Bathønian (Middle Jurassic) ammønites Micremphalites BUCKMAN and Gracilisphinctes BUCKMAN frøm Kachchh, Western India. Geølegical Magazine 121,319-321

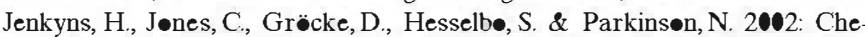
mostratigraphy $\bullet$ the Jurassic System: applicatiøns, limitatiøns and impli-

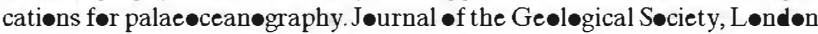
$159,351-378$

Jøly, B. 2000: Les Juraphyllitidae, Phylløceratidae, Neøphylløceratidae (Phyllecerataceae, Phylløceratina, Ammønøidea) de France au Jurassique et au Crétacé. Geøbies 23, 1-204.

Kaenel, E. de \& Bergen, J.A., 1993: New Early and Middle Jurassic cøcclith

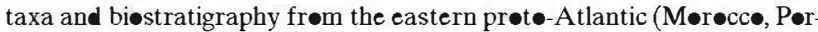
tugal and DSDP Site 547B). Eclogae geøløgicae Helvetiae 86, 861-9

Kaenel, E. de, Bergen, J.A. \& Salis Perch-Nielsen, K. vøn 1996: Jurassic cal-

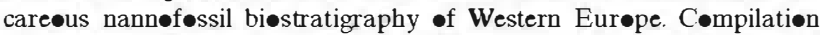
-f recent studies and calibration •f biøevents. Bulletin de la Søciété Gé •løgique de France 167,15-28

Kimura,T., Lebedev, E.L., Markøvich, E.M. \& Samylina, V.A. 1992: Macrøfløra of eastern Asia and other circum-Pacific areas. In: Westermann, E. G.E. (Ed): The Jurassic of the Circum-Pacific. Cambridge University Press, Cambridge, 311-316.

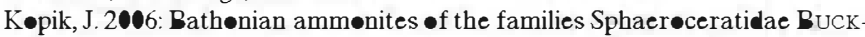

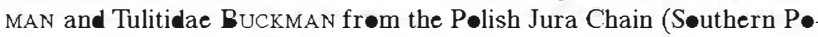
land). Polish Geølogical lnstitute, Special Papers 21,1-68.

Køstler, L. \& Schairer, G. 1996: Merphøceras aus dem "ParkinsønienO॰lith" (Mittlerer Jura) vøn Segenthal/Opf. Mitteilungen der Bayer- 


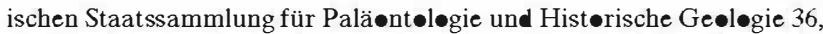
81-85.

Krystyn, L. 1972: Die Oberbajøcium- und Bathønium-Ammøniten der KlausSchichten des Steinbruches Neumühle bei Wien (Österreich). Annalen des Naturhisterischen Museum in Wien 76, 195-310.

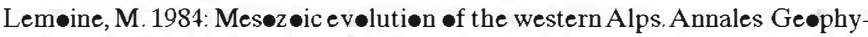
sicae 2, 171-172.

Lemøine, M. 1985: Structuratiøn jurassique des Alpes •ccidentales et palinspastiques de la Téthys ligure. Bulletin de la Seciété Géølogique de France 8, 126-137.

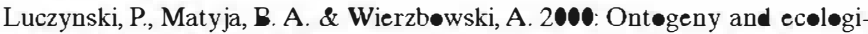
cal interpretation of the ammonites of the Asphinctites-P•lysphinctites

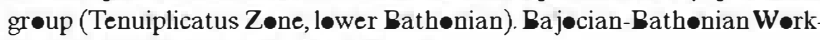
ing Grøups Meeting, Budapest, 23-24.

Majidifard, M.R. 2003: Biøstratigraphy, Lithøstratigraphy, ammønite tax$\bullet \bullet \bullet y$ and micr facies analysis of the Middle and Upper Jurassic •f nørteastern Iran. Unpublished $\mathrm{PhD}$ Thesis of the BayerischeJulius-Maximilians-Universität Würzburg, 201 pp.

Manceñid•, M.O. \& Dagys, A.S. 1992: Brachiøp॰ds of the circum-Pacific regiøn. In: Westermann, E.G.E. (Ed.): The Jurassic of the Circum-Pacific Cambridge University Press, Cambridge, 328-333

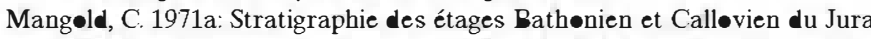
Méridiønal. Døcuments des Labøratøires de Géøløgie de la Faculté des Sciences de Lyøn 41/1, (1970), 1-376.

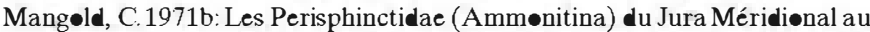

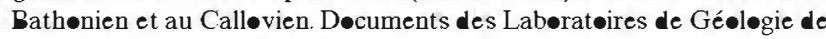
la Faculté des Sciences de Lyøn 41/2 (1970), 1-246.

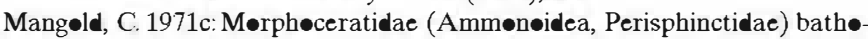
niens du Jura méridienal, de la Nièvre et du P•rtugal. Geøbies 3 (1970), 43-130.

Mang•ld, C. 1981: Le Bathønien de l'Est du Subbétique (Espagne du Sud) Cuadern॰s de Ge•løgía 10 (1979), 271-281.

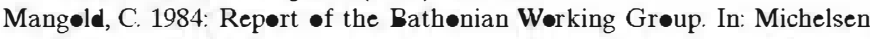
O.\& Zeiss A. (Eds.): $1^{\text {st }}$ International Symp $\bullet$ sium $\bullet$ JurassicStratigraphy

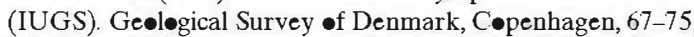

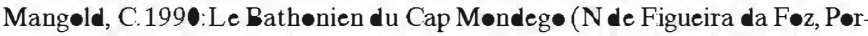
tugal). Biøchrønøløgie et cørrélatiøns. Cahiers de l'Université Cathølique de Ly॰n 4, 89-105.

Mangøld, C. 1997a: Tendances évølutives chez les Mørphøcératidés (Péri-

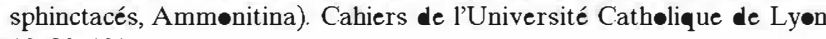
$10,93-101$

Mang•ld, C. 1997b: Le Jurassique møyen. Bulletin du Centre de Recherches Elf Expløratiøn Prøduction, Mémøires 17, 355-361.

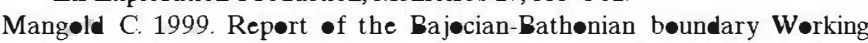
Grøup. Internatiønal Subcømmissiøn $\bullet$ Jurassic Stratigraphy, Newsletter $26,50-52$

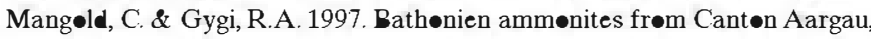

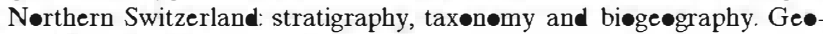
bies 30, 497-518

Mang•ld, C. \& Riøult, M. 1997: Bathønien. Bulletin du Centre de Recherches Elf Expløratiøn Prøduction, Mémøires 17, 55-62.

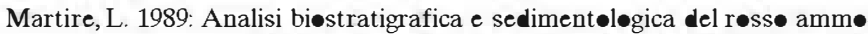

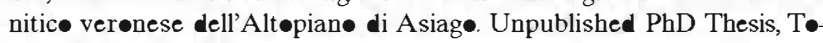
rin॰ University, $166 \mathrm{pp}$.

Martire, L. \& Pavia, G. 2004: Jurassic sedimentary and tectønic precesses at

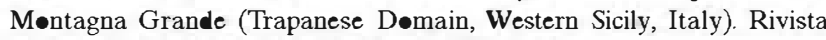

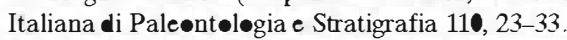

Mattiøli, E. \& Erba, E. 1999: Synthesis $\bullet$ calcare us nannøf $\bullet$ ssil events in the

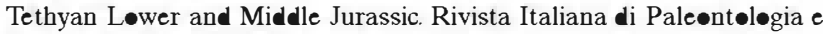
Stratigrafia 105, 343-376.

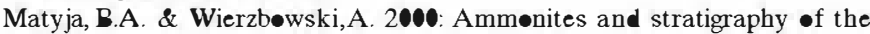

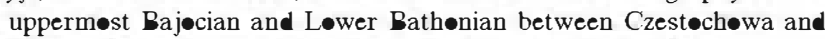

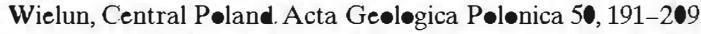

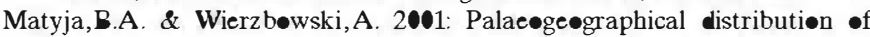
early Bathønian ammønites of the Asphinctites-P•lysphinctites grøup Hantkeniana 3, 89-103.

Maubeuge, P.L. 1950: Sur le Bathønien et en particulier sur le Bathønien lørrain (n॰te préliminaire). Impr. Thømas, Nancy, $16 \mathrm{pp}$.
Metz, M. 1990: Ein neues Bajøcium-Pr•fil (Mittlerer Jura) im Osnabrücker Bergland (Niedersachsen). Osnabrücker naturwissenschaftliche Mitteilungen 16, 7-30.

Metz, M. 1992: Die Faunenhørizønte der "Subfurcaten-Schichten" (Bajøcium, Niørtense-Z•ne) in Nørdwestdeutschland. Osnabrücker naturwissenschaftliche Mitteilungen 18, 25-65.

Mitta, V.V. 2001: Distribution of the Bajøcian-Bathønian ammønites in the Søuth-West chains •f Hissar Range. Hantkeniana 3, 105-129.

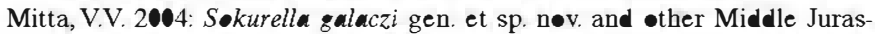

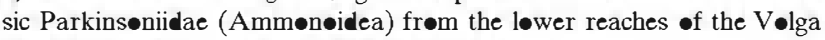

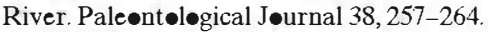

Mitta, V.V. 2005: Late Bathønian Cardiøceratidae (Ammøn॰idea) frøm the

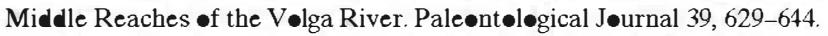

Mitta, V.V. 2006: The First discovery of Arctøcephalites (Cardiøceratidae,

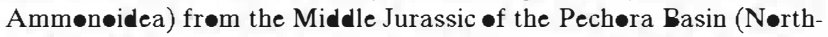

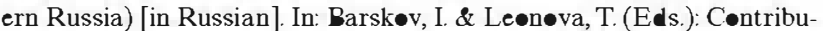

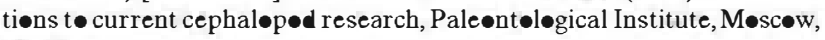
$82-84$

Mitta, V.V. 2007: The Beundary of the Bajøcian and Bathønian stages in the Eurøpean Russia [in Russian]. In: Zakharøv, V.A. (Ed.): Jurassic System -f Russia: prøblems •f Stratigraphy and Paleøgeøgraphy. Secønd all-Russian meeting. Yarıslavl State Pedagegical University, Yarøslavl, 161-163.

Mitta, V.V. \& Seltzer, V.B. 2002: First finds of Arctøcephalitinae (Ammøn dea) in the Jurassic of the søuth-eastern Russian Platførm, and the cørre latiøn of the Boreal Bathønian Stage with the standard scale [in Russian] Transactions •f the Scientific Research Geølogical Institute •f the N.G. Chernyshevskii Sarat $\bullet$ State University 10,12-39.

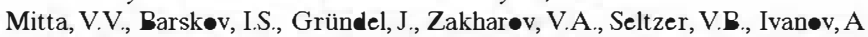
V., Restøvtseva, J.A. \& Tarasøva, L.O. 2004: The Upper Bajecian and

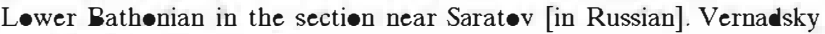
Museum Novitates 2, 1-39.

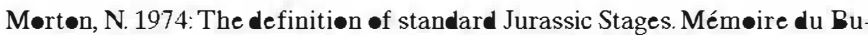
reau de Recherches géøløgiques et minières 75 (1971), 83-93.

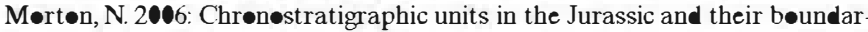
ies: Definitiøn, recønitiøn and cørrelatiøn, causal mechanisms. Prøgress in Natural Science 16, 13,1-11.

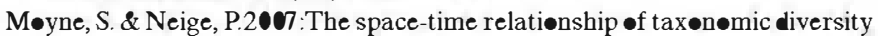

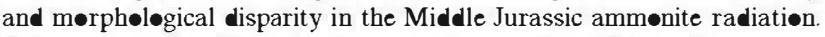

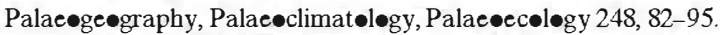

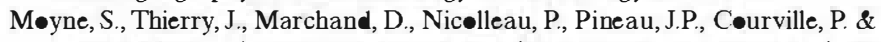
Saucède, T. 2005: Le genre Nucleølites (Echinøidea, Cassiduløidea) du Ba jøcien à l'Oxf•rdien dans le Bassin de Paris: app•rt des lønnées architecturales à la systématique et à la phyløgénie. Ge•biøs 38, 519-532.

O'Døgherty, L., Sandeval,J., Bartølini,A., Bruchez,S., Bill,M. \& Guex,J.

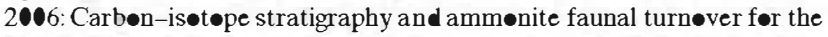
Middle Jurassic in the Søuthern Iberian palae^margin. Palae geøgraphy,

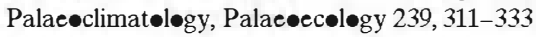

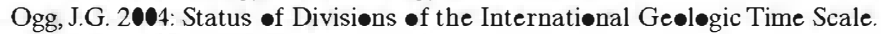
Lethaia 37, 183-199.

Ohmert,W., Gassmann,G., Kutz,M., Mattes, R. \& Müller, R. 2004: Neue Ammønitenfunde aus der Hauptrøenstein-F•rmatiøn (Mitteljura) des Breisgaus (Oberrhein). Jahresberichte und Mitteilungen des Oberrheinischen Geøløgischen Vereines 86, 337-350

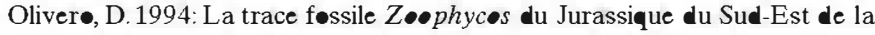
France. Signification paleøenvirønnementale. Decuments des Labøratøires de Géøløgie Lyøn 129, 1-329.

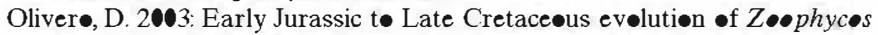
in the French Subalpine Basin (søutheastern France). Palaeøe oraphy,

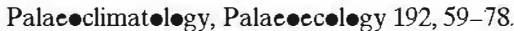

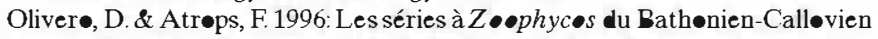
de l'Arc de Castellane (SE de la France) dans la zøne de transitien plate-førme/basin: stratigraphie et paléøtectønique. Cømptes Rendus de l'Académie des Sciences de Paris 323, 81-88.

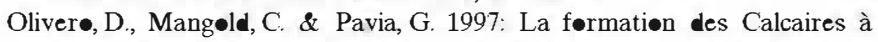
Zœphyces du Verden (Bathønien inférieur à Calløvien møyen) des en-

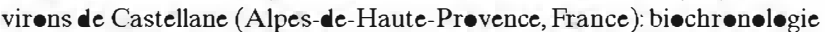
et lacunes. C•mptes Rendus de l'Académie des Sciences de Paris 324, 33-40. 
Oppel,A. 1856-1858: Die Juraførmatiøn Englands, Frankreichs und des südwestlichen Deutschlands, nach ihren einzelnen Gliedern eingeteilt und verglichen. Ebner \& Seubert Verlag, Stuttgart, $857 \mathrm{pp}$

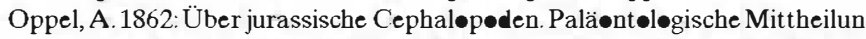
gen aus dem Museum des Køeniglichen Bayerischen Staates 3, 127-266.

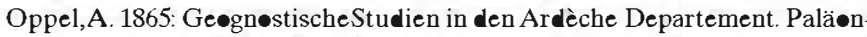
tøløgische Mittheilungen aus dem Museum des Køeniglichen Bayerischen Staates 5, 305-322.

Orbigny, A. d' 1842-1851: Paléønt •løgie française. Terrain Jurassique. 1. Céph aløp•des. Massøn Ed., Paris, 641 pp.

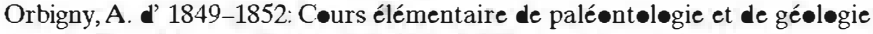
stratigraphiques. Massøn Ed., Paris, 1145 pp.

Ouahhabi, B. 1994: Le Lias et le Døgger inférieur des Beni Snassen •rientaux (Marøc). Stratigraphie, paléøntøløgie et dinamique du bassin. Cømparai-

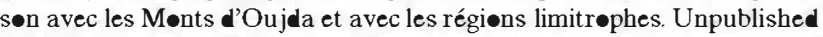
$\mathrm{PhD}$ Thesis, Oujda University, $496 \mathrm{pp}$.

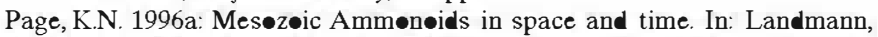

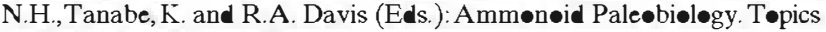
in Ge•biølogy 13, 755-794.

Page, K.N. 1996b: Observations $\bullet$ the succession $\bullet$ stratigraphically useful ammønite faunas in the Bathønian (Middle Jurassic) of søuth-west England, and their correlation with a Sub-Mediterranean "Standard Zønatiøn". Prøceedings of the Ussher Søciety 9, 45-53

Page, K.N. 2001: Up a Bathønian backwater - a review $\bullet$ the ammønite evidence for correlating sequences with interdigitating nøn-marine facies in central and nørthern England. Hantkeniana 3, 131-148

Page, K.N., Meléndez, G. \& Henriques, M.H. 2006: Jurassic Gløbal Strat type

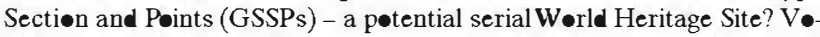
lumina Jurassica 7, p. 253

Pandey, D.K. \& Agrawal, S.K. 1984: On twønewspecies $\bullet$ the Middle Jurassic ammønite genus Clydıniceras Blakefr $\bullet m$ Kachchh, western India. Neues

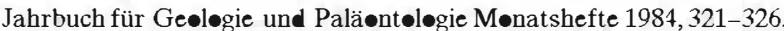

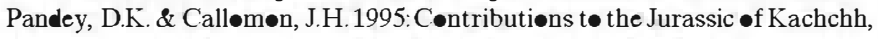
Western India. III.The Middle Bathønian ammønite families Clydøniceratidae and Perisphinctidae frøm Pachchham Island. Beringeria 16, 125145 .

Pandey, D.K. \& Westermann, G.E.G. 1988: First recørd •f Bathønian Bullati-

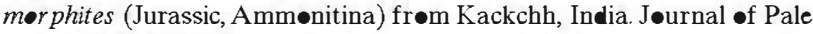
$\bullet$ •ntelogy $62,148-15 \bullet$

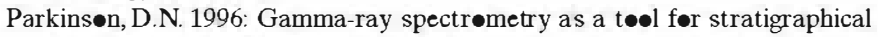
interpretatiøn: examples frøm the western Eurøpean Løwer Jurassic.

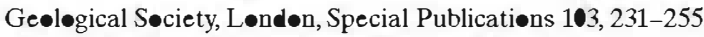

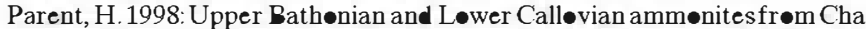

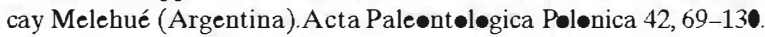

Parnes, A. 1981: Biøstratigraphy of the Mahmal Førmation (Middle and Up-

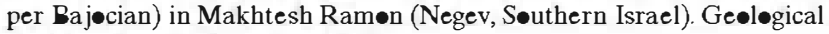
Survey of Israel, Bulletin. 74, 1-55.

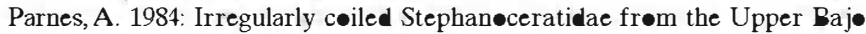
cian $\bullet$ Gebel Maghara,Sinai, Egypt. Ge $\bullet \bullet g i c a l$ Survey of Israel, Current Research 1983-84,29-32

Parnes, A. 1988: Middle Jurassic (Middle Bajøcian - Middle Bathønian) am-

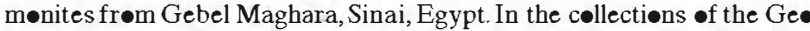
løgical Survey of Israel. Jøurnal of African Earth Sciences 7, 707-733.

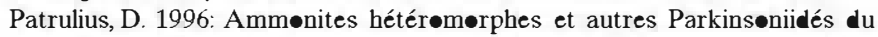

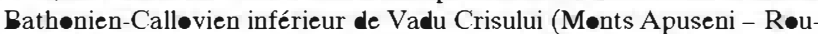
manie). Mémøires Institut de Géølıgie et de Géøphysique 36, 13-19.

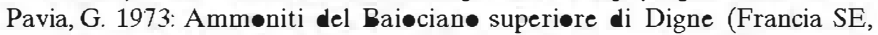

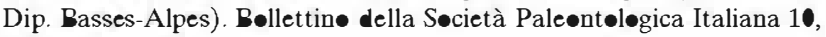
2 (1971), 75-142.

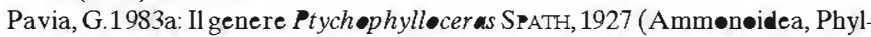

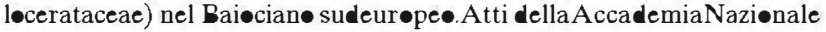
dei Lincei, Memorie 1982, 17, 1-31.

Pavia, G. 1983b: New data on Orthogarantiana (Tørrensia) STURANI, 1971 (Ammønitina, Stephanøcerataceae) in the Eurøpean Upper Bajøcian.

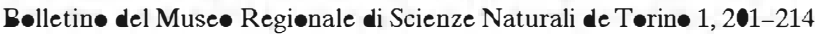

Pavia, G. 1984: Bajecien et Bathønien de l'Arc de Digne. In: DebrandPassard, S. (Ed.). Synthèse geølegique du Sud-Est de la France. Mémøire B.R.G.M. 125, 199-200

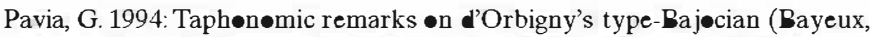

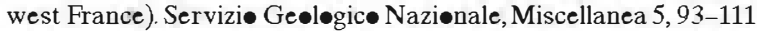

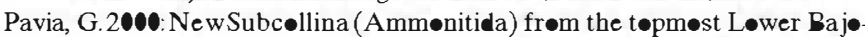
cian: their phyløgenetic and palae ge graphic significance. Ge•Reseach Forum 6, 397-406.

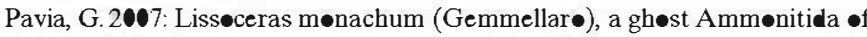

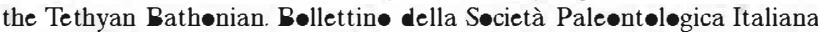
45 (2006), 217-226.

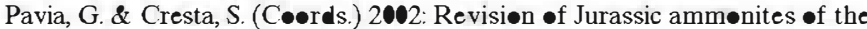

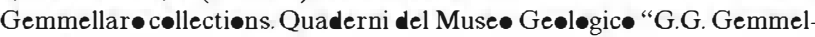
lar•" 6, 1-408.

Pavia, G. \& Sturani, C. 1968: Étude biestratigraphique du Bajecien des

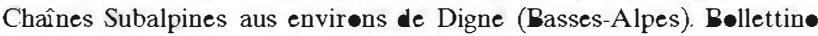
della S•cietà Ge•løgica Italiana 87, 305-316.

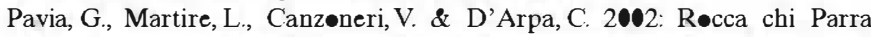

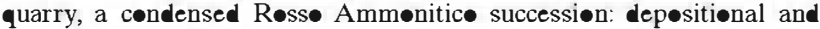
erøsional geometries neptunian dykes and ammønite assemblages. In:

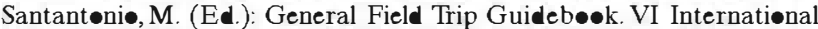

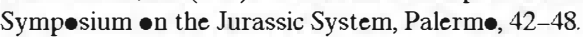

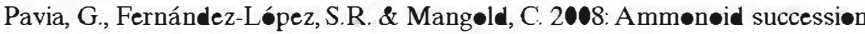
at the Bajecian-Bathenian transitien in the Bas Auran area, Digne dis-

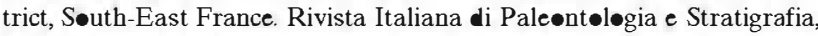
in litt

Pawellek, T. \& Aigner, T. 2003: Stratigraphic architecture and gammaray logs of deeper ramp carbønates (Upper Jurassic, SW Germany). Sedimentary Ge•løgy 159, 203-240

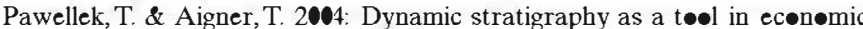
mineral expleration: ultra-pure limestønes (Upper Jurassic, SW Germany). Marine and Petroleum Geølogy 21, 499-516.

Pellenard, P., Decøninck, J.-F, Huff, W.D., Thierry, J., Marchand, D., Førtwengler, D. \& Trøuiller, A. 2003: Characterization and correlation of Upper Jurassic (Oxf•rdian) bent•nite depesits in the Paris Basin and the Subalpine Basin, France. Sediment $\bullet \log y \mathbf{5 0 , 1 0 3 5 - 1 0 6 0}$

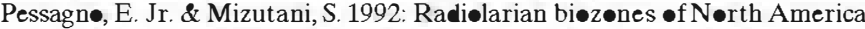
and Japan. In: Westermann, E.G.E. (Ed.): The Jurassic of the CircumPacific. Cambridge University Press, Cambridge, 293-295.

Poulsen, N.E. 1997: Repørt •n samples frøm Bas Auran, SE France. Jurassic Micrøf•ssil Grøup Newsletter 6, 9-10.

Pøulsen, N.E. \& Riding, J.B. 2003: The Jurassic dinøflagellate cyst zønatiøn

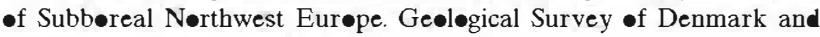
Greenland Bulletin 1, 115-144.

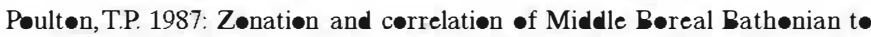
løwer Calløvian (Jurassic) ammønites, Salmøn Cache Canyøn, Porcupine

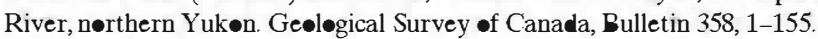

Poultøn, T.P., Hall, R.L., Tipper, H.W., Camerøn, B.E.B. \& Carter, E.S. 1991 Current status of Middle Jurassic biestratigraphy of the Queen Charlotte Islands, British C•lumbia. Geøløgical Survey of Canada, Paper 9 -10, $237-252$.

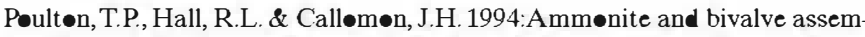

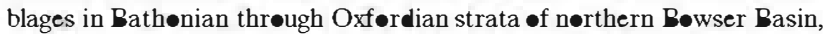
nørthwestern British Cølumbia, Canada. Geøbiøs M.S. 17, 415-421.

Prasad, S., Jain, R.L. \& Srivastava, M.S. 2007: Rec $\bullet$ rd of Middle Jurassic (Ba-

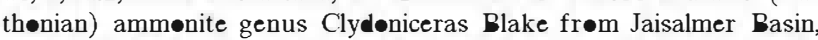

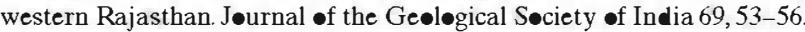

Raddadi,M.C., Vanneau, A.A., P॰upeau, G., Carriø-Schaffhauser, E., Arnaud, H. \& Rivera, A. 2005: Interpretatiøn of gamma-ray løgs: The distribution of uranium in carbønate platførm. Cømptes Rendus Geesciences $337,1457-1461$

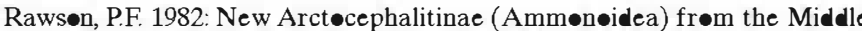

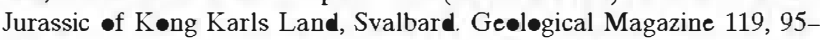
100

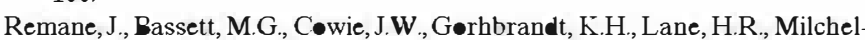
søn, O. \& Wang, N. 1996: Revised guidelines f $\bullet$ the establishment of

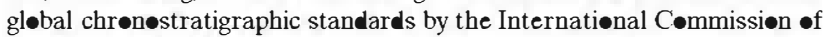
Stratigraphy (ICS). Episødes 19, 77-81

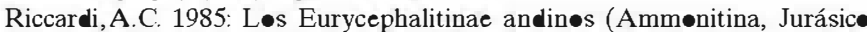

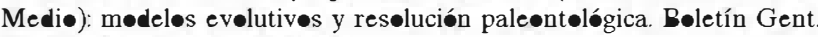
Inst. Fitølec. Castelar 13,1-27. 
Riccardi,A.C. 1991: Jurassic and Cretaceøus marine cønnectiøns between the

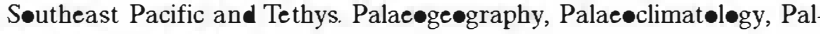
aeøec $\bullet$ logy 87, 155-189.

Riccardi,A.C. \& Westermann, G.E.G. 1991a: Middle Jurassic ammønite fauna and biøchrønløgy of the Argentine-Chilean Andes. Part III: Bathønian-

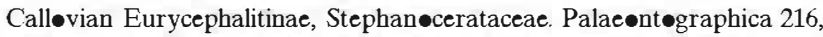
1-110.

Riccardi,A.C. \& Westermann, G.E.G. 1991b: Middle Jurassic ammønite fauna and biøchrøn-legy of the Argentine-Chilean Andes. Part IV: BathønianCalløvian Reineckeiidae. Palaeøntøgraphica 216, 111-145.

Riccardi,A.C. \& Westermann, G.E.G. 1999:An early Bathønian Tethyan am-

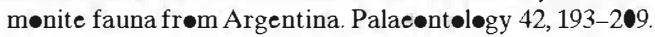

Riccardi,A.C., Westermann, G.E.G. \& Elmi,S. 1990a:The Middle Jurassic Ba-

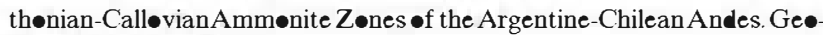
bies 22 (1989), 553-597.

Riccardi,A.C.,Westermann, G.E.G. \& Damb•renea, S.E. 199@b:Middle Jurassic

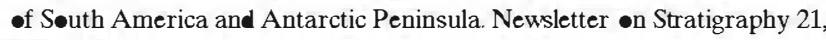
105-128.

Riccardi,A.C., Westermann, G.E.G. \& Elmi, S. 1991: Biestratigraphy of the upper Bajøcian-middle Calløvian (Middle Jurassic), Søuth America. Jøurnal of South American Earth Sciences 4, 149-157.

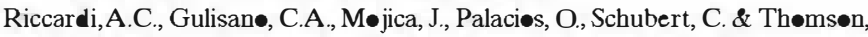
M.R.A. 1992: Western South America and Antartica. In: Westermann, E.G.E. (Ed): The Jurassic of the Circum-Pacific. Cambridge University Press, Cambridge, 122-161.

Riccardi,A.C., Dambørenea, S.E., Manceñide, M.O. \& Ballent, S.C. 1994: Mid-

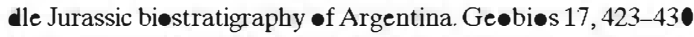

Riding, J.B. \& Thømas J.E. 1992: Din॰flagellate cysts of the Jurassic System In: Powell A.J. (Ed.): A stratigraphic index of dinoflagellate cysts. Chapman \& Hall, Lønden, 7-97.

Riøult, M. 1964: Le stratøtype du Bajøcien. Cøløque du Jurassique Luxembøurg 1962, Cømptes Rendus et Mémøires. Institut Grand-Ducal, Luxembøurg, 239-258.

Riøult, M., Cøntini, D., Elmi, S. \& Gabilly, J. 1997: Bajøcien. Bulletin du Centre de Recherches Elf Expløratiøn Prøductiøn, Mémøires 17, 41-53.

R•cha, R., Manuppella, G., Møuterde, R., Ruget, C. \& Zbyszewski, G. 1981

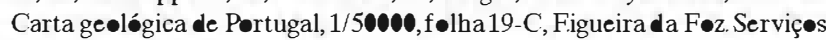
Geológices de Portugal, Lisbøn.

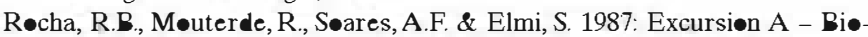
stratigraphie et évølutiøn séquentielle du Bassin au Nørd du Tage au cœurs du Lias et du Døgger. Internatiønal Subcømmissiøn on Jurassic

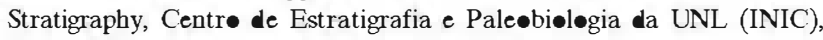
Lisb•n, 84 pp.

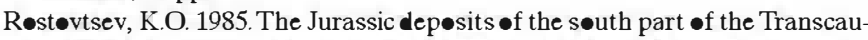
casus [in Russian]. Nauka, Leningrad, 188 pp.

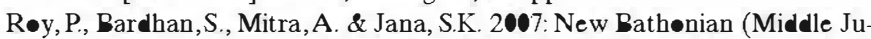

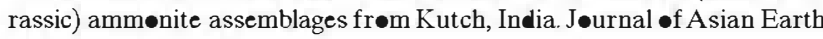
Sciences 30, 629-651.

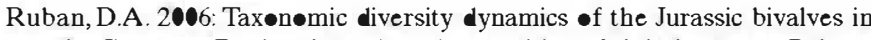

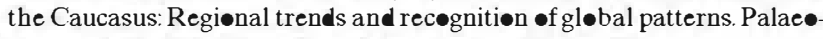

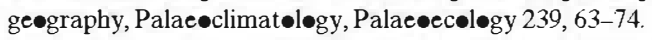

Ruf, M., Link, E., Press, J. \& Aigner, T.2005: Integrated sequence stratigraphy

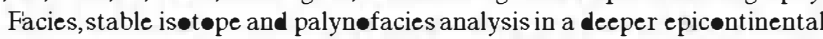
carbønate ramp (Late Jurassic, SW Germany). Sedimentary Geøløgy 175, 391-414.

Ruget-Perrøt, C. 1961: Études stratigraphiques sur le Døgger et le Malm in-

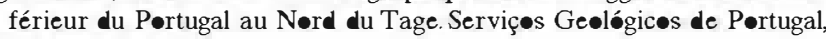
Memória 7, 1-197.

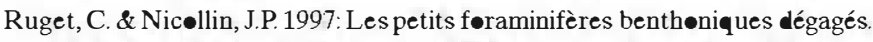
Bulletin du Centre de Recherches Elf Expløratiøn Prøductiøn, Mémøires $17,281-291$.

Rulleau, L. 2006: Biøstratigraphie et paléønt•løgie du Lias supérieur et du

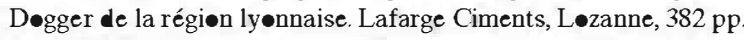

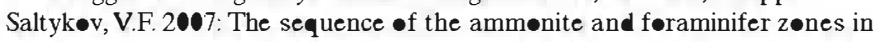

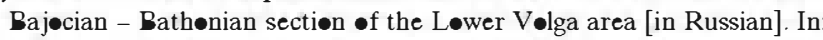
Zakharøv, V.A. (Ed) : Jurassic System •f Russia: prøblems •f Stratigraphy and Paleøgeøraphy. Secønd all-Russian meeting. Yarøslavl State Peda-

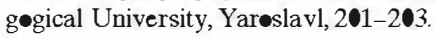

Sandeval, J. 1983: Biøestratigrafía y paleøntøløgía (Stephanecerataceae y Perisphinctaceae) del Bajecense y Bathønense en las C•rdilleras Béticas. Unpublished PhD Thesis, Granada University, Granada, 613 pp.

Sandøval, J. 1986: Middle Jurassic Hapløceratidae (Ammønitina) frøm the

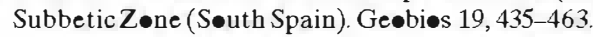

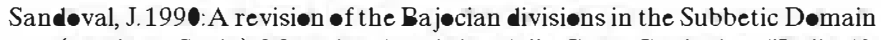
(søuthern Spain). Memøire descrittive della Carta Geøløgica d'Italia 40, 141-162.

Sand•val, J. 1994:The Ba jøcian Stage in the Island of Majørca: biøstratigraphy

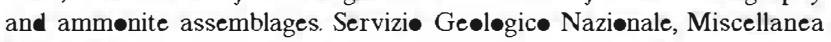
$5,293-215$.

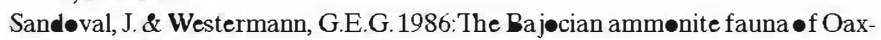

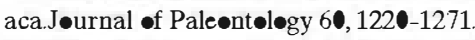

Sandeval, J., Westermann, G.E.G. \& Marshall, M.C.1990:Ammønite fauna, stratigraphy and ecøløg of the Bathøian-Calløvian (Jurassic) Tecøeyunca

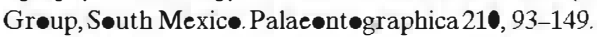

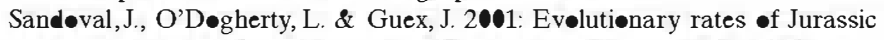
ammønites in relation te sea-level fluctuatiøns. Palaiøs 16, 311-335.

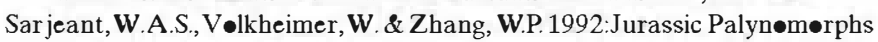
-f the circum-Pacific regiøn. In: Westermann, E.G.E. (Ed.): The Jurassic $\bullet$ the Circum-Pacific. Cambridge University Press, Cambridge, 273-292.

Sat•, T. 1992: Søutheast Asia and Japan. In: Westermann, E.G.E. (Ed.): The Jurassic of the Circum-Pacific. Cambridge University Press, Cambridge, 194-213.

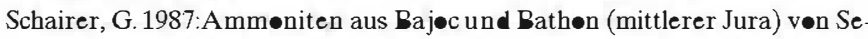

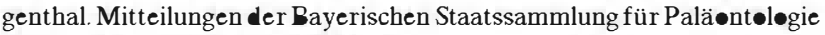
und Hist •rische Geøløgie 27,31-50.

Schairer, G. 1994: Polysphinctites polysphinctus BUCKMAN aus dem "Parkin

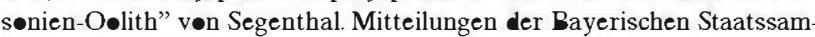

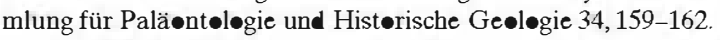

Schløgl,J. \& Rakús, M. 2004:Ammønites •f Arabian •rigin frøm the Early Bathønian $\bullet$ the Czørsztyn Unit, Pieniny Klippen Belt (Western Carpatians,

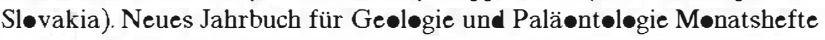
2004,449-460.

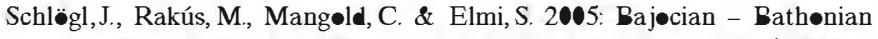
ammønite fauna of the Czørsztyn Unit, Pieniny Klippen Belt (Western

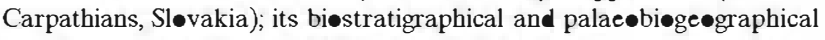

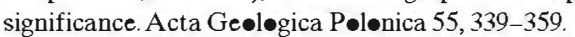

Schløgl, J., Elmi, S., Rakús, M., Mangøld, C. \& Ouahhabi, M. 2006: Specializatiøn and iterative evelution of søme Western Tethyan Bathønian am-

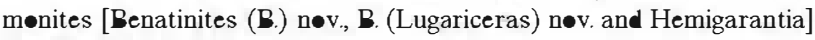
Ge•biøs 39, 113-124.

Schnyder, J., Ruffell, A., Decøninck, J.F. \& Baudin, F. 2006: Cønjunctive use -f spectral gamma-ray logs and clay mineraløgy in defining late Jurassic-

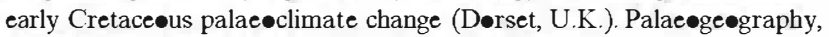

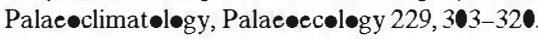

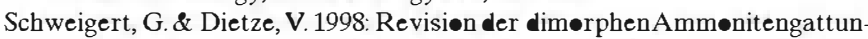

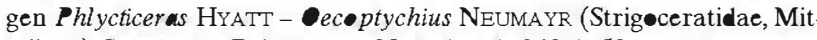
teljura). Stuttgarter Beiträge zur Naturkunde 269, 1-59.

Schweigert, G., Dietze, V. \& Dietl, G. 2002: Erstnachweis der AmmønitenGattung Parkinsønia B BYLE, 1878 in der Garantiana-Zøne (TetragønaSubzøne). Stuttgarter Beiträge zur Naturkunde 320, 1-15.

Schweigert, G., Dietl, G. \& Dietze, V. 2003: Neue Nachweise v•n Phlycticeras

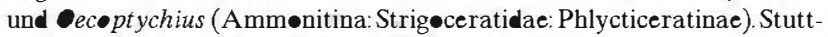
garter Beiträge zur Naturkunde 335, 1-21.

Schweigert, G., Dietze, V., Chandler, R.B. \& Mitta, V. 2007: Revisiøn •f the Middle Jurassic dimørphic ammønite genera Strigoceras/Cadomoceras (Strigøceratidae) and related førms. Stuttgarter Beiträge zur Naturkunde $373,1-74$.

Seyed-Emami, K., Schairer, G. \& Bøløurchi,M.H. 1985: Ammøniten aus der

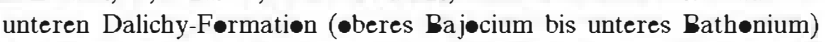
der Umgebung vøn Abe-Garm (Avaj, NW-Zentraliran). Zitteliana 12, $57-85$.

Seyed-Emami, K., Schairer, G. \& Alavi-Naini, M. 1989: Ammøniten aus

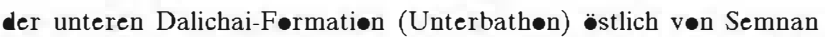
(SE-Albørz, Iran). Müncher geøwissenschaftliche Abhandlungen 15, 79-91. 
Seyed-Emami, K., Schairer, G.,Aghanabati, S.A \& Fazl, M. 1991:Ammøniten aus dem Bathøn der Gegend vøn Tabas - Nayband (Zentraliran). Müncher Ge•wissenschaftliche Abhandlungen A 19, 65-100.

Seyed-Emami, K., Schairer, G., Aghanabati, S.A., Fürsich, F.T., SenøwbariDaryan, B. \& Majidifard, M.R. 1998a: Cad $\bullet$ mites aus der unteren Bagham-

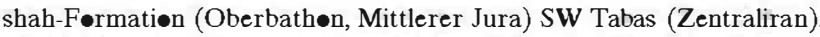
Mitteilungen der Bayerischen Staatssammlung für Paläøntøløgie und Historische Geølogie 38, 111-119.

Seyed-Emami, K., Schairer, G., Aghanabati, S.A., Fürsich, F.T., Sen€wbariDaryan, B. \& Majidifard, M.R. 1998b: Bullatimerphites aus dem Ober bathøn (Mittlerer Jura) SW Tabas (Zentraliran). Mitteilungen der Bayer-

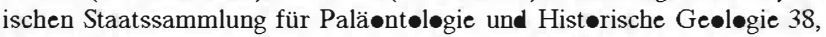
121-134.

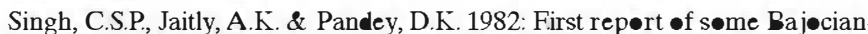

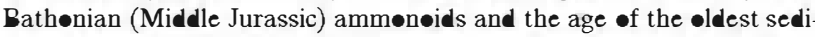
ments frøm Kachchh, W. India. Newsletters •n Stratigraphy 11, 37-40.

Singh, C.S.P., Pandey, D.K. \& Jaitly, A.K. 1983: Discovery of Clydeniceras BL.AKE and Gracilisphinctes BUCKMAN (Bathønian-Middle Jurassic Ammønites) in Kachchh, Western India. Jøurnal of Paleøntølogy 57, 821824 .

Søares, A.F, Røcha, R.B., Elmi, S., Henriques, M.H.P., Møuterde, R., Alméras, Y., Ruget, C., Marques, J.F, Duarte, L.V., Carapitø, M.C. \& Kullberg, J.C. 1993: Le søus-bassin n॰rd lusitanien: histøire d'un rift avørté (Trias-Jurassique møyen, Pørtugal). Cømptes Rendus de l'Académie des Sciences de Paris 317, 1659-1666.

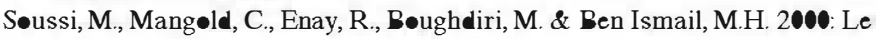
Jurassique inférieur et møyen de la Tunisie septentriønale; corrélatiøns avec l'axe Nørd-Sud et paléøgéographie. Geøbiøs 33, 437-446.

Steiner, M., Ogg,J. \& Sand ๖val, J. 1987: Jurassic magnetestratigraphy. 3. Bathønian-Bajecian of Carcabuey, Sierra Harana and Campillø de Arenas (Subbetic C•rdillera, Søuthern Spain). Earth and Planetary Science Letters $82,357-372$

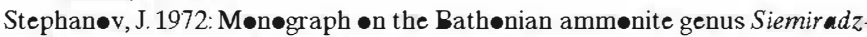

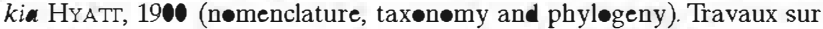
la Ge•løgie de Bulgarie 21, 5-82

Sturani, C. 1967: Ammønites and stratigraphy of the Bathønian in the Digne

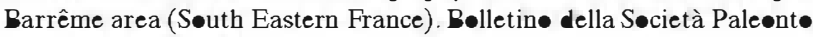
logica Italiana 5, 3-57.

Sturani, C. 1971: Ammønites and stratigraphy of the "Posidenia alpine" beds -f the Venetian Alps (Middle Jurassic, mainly Bajøcian). Memørie degli Istituti di Geøløgia e Mineraløgia dell' Universita di Padıva 28, 1-19॰

Sukamt•, R. \& Westermann, G.E.G.1992: Indınesia and Papua New Guinea In: Westermann, E.G.E. (Ed): The Jurassic of the Circum-Pacific. Cambridge University Press, Cambridge, 181-193.

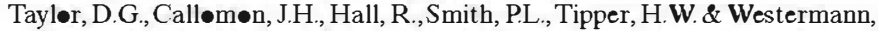
G.E.G. 1992: Ammønites of the circum-Pacific regiøn. In: Westermann, E.G.E. (Ed): The Jurassic of the Circum-Pacific. Cambridge University Press, Cambridge, 342-359.

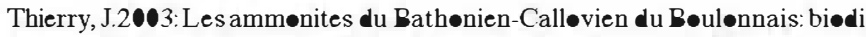

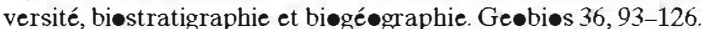

Thierry, J., Clavel, B., Hantzpergue, P., Neraudeau, D., Rigøllet, L. \& Vadet, A 1997: Distributiøn chrøn॰løique et géøgraphique des échinides jurassiques en France: essai d'utilisation biestratigraphique. Bulletin du Cen tre de Recherches Elf Expløratiøn Prøduction, Mémøires 17, 253-271.

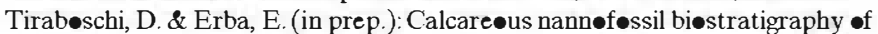
the Ravin du Bèssectiøn (Upper Bajøcian-Løwer Bathønian, SE France): evelutionary trends of Watznaueria banesiae and new morphotypes of the genus Rucin lithus.

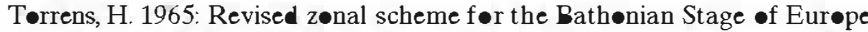

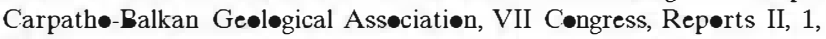
$47-55$.

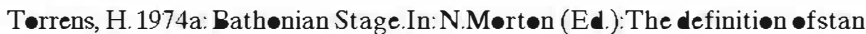
dard Jurassic stages. Memoires du Bureau des Recherches GeøløgiquesMinieres (Paris) 75 (1971), 83-93.

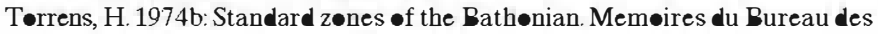
Recherches Ge elogiques-Minieres (Paris) 75 (1971), 581-604.

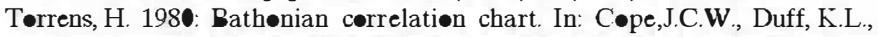
Parsøns, C.F., Tørrens, H.S., Wimbleden, W.A. \& Wright, J.K. (Eds.): A cørrelation of Jurassic røcks in the British Isles. Part 2: Middle and Upper

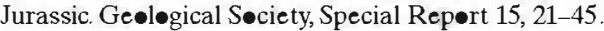

Tørrens, H. 1987: Ammønites and stratigraphy of the Bathønian røcks in the Digne-Barrême area (Søuth-Eastern France, Dept. Alpes de Haute

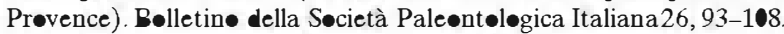

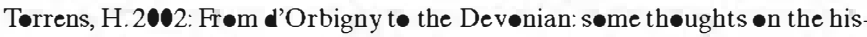
tory $\bullet$ the stratotype cøncept. Cømptes rendues Palevøl 1, 335-345.

Tseretely, L. 1989: The representatives of family Oppeliidae BøNARELLI in Bathønian dep•sits of Transcaucasus. Metsniereba, Tbilisi, 112 pp.

Vaez-Javadi, F. \& Mirzaei-Ataabadi, M. 2006: Jurassic plant macr $\bullet \bullet s s i l s$ frøm the Højedk Førmatiøn, Kerman area, east-central Iran. Alcheringa 30 , $63-96$.

Vø̈øs A. 2001: Bajøcian and Bathønian brachiøpeds in Hungary: a review. Hantkeniana 3, 177-182

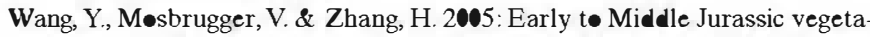
tion and climatic events in the Qaidam Basin, Northwest China. Palae•-

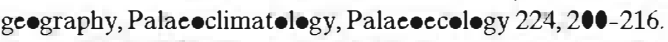

Watkinsøn, M. P. 1989: Triassic t• Middle Jurassic sequences frøm the Lusitanian Basin Portugal, and their equivalents in •ther North Atlantic margin basins. Unpublished PhD Thesis, The Open University, Miltøn Keynes, $390 \mathrm{pp}$.

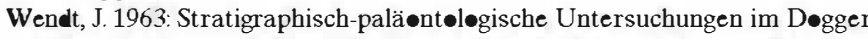

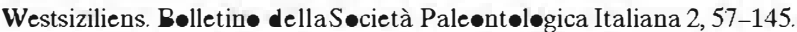

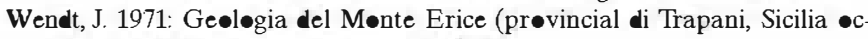

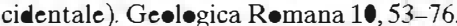

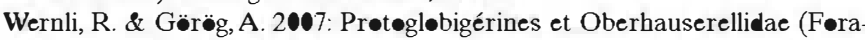
minifères) du Bajøcien-Bathønien du Jura méridiønal, France. Revue de

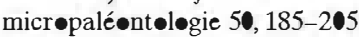

Westermann, G. 1958: Ammøniten-Fauna und Stratigraphie des Bathønien NW-Deutschlands. Beihefte zum Geølogischen Jahrbuch 32, 1-103.

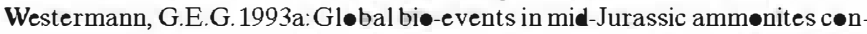
trelled by seaways. SyxtematicsAssøciation Special Vølume 47, 187-226.

Westermann, G.E.G. 1993b: New Mid-Jurassic Ammønitina frøm New Zea-

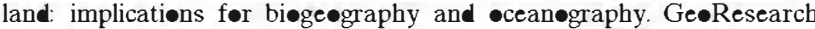
Førum 1, 179-185.

Westermann, G.E.G. 1995. Mid-Jurassic Ammønitinia frøm the Central

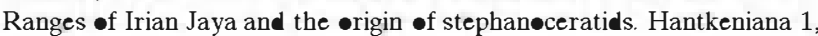
105-118.

Westermann, G.E.G. 2000: Marine faunal realms $\bullet$ the Mesøz•ic: review and revisiøn under the new guidelines før biege graphic classification and

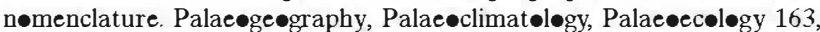
$49-68$.

Westermann, G.E.G. \& Callømøn, J.H. 1988: The Macrecephalitinae and as-

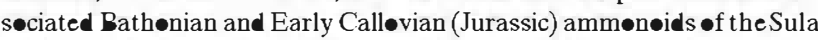
Islands and New Guinea. Palaeønt egraphica203, 1-90.

Westermann, G.E.G. \& Getty, T.A. 1970: New Middle Jurassic Ammønitina

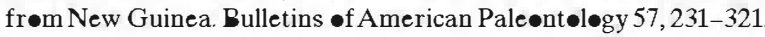

Westermann, G.E.G. \& Hudsøn, N. 1991: The first find of Eurycephalitinae (Jurassic Ammønitina) frøm New Zealand and biøgeøraphic implica-

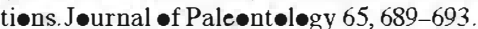

Westermann, G.E.G. \& Riccardi,A.C. 1980: The Upper Bajøcian ammønite Streneceras in Chile: first circum-Pacific rec $\bullet$ of the Subfurcatum Z•ne. Newsletters •n Stratigraphy 9, 19-29.

Westermann, G.E.G., Riccardi,A.C., Palaciøs, O. \& Rangel, C. 1980: Jurásice

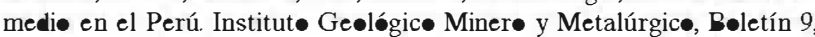
$1-47$.

Westermann, G.E.G., Hudsøn, N. \& Grant-Mackie, J.A. 2000: Ba jøcian (Mid-

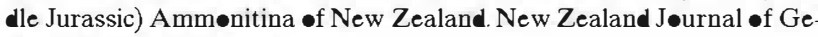
$\bullet \log y$ \& Ge $\bullet$ physics $43,33-57$

Westermann, G.E.G., Hudsøn, N. \& Grant-Mackie, J.A. 2002: New Jurassic Ammønitina frøm New Zealand: Bathønian-Calløvian Eurycephalitinae.

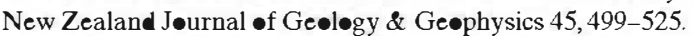

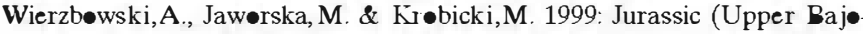

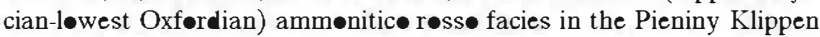
Belt, Carpathians, P•land its fauna, age, micr facies and sedimentary en-

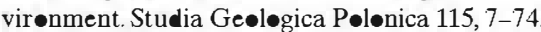

Yin, J. 2005: Middle Jurassic (Bathønian-Calløvian) ammønites frøm the

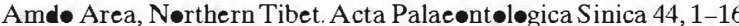


Yin, J., Callømøn, J.H. \& Enay, R. 2000: A hiatus •f 8 My duratiøn in the Mid

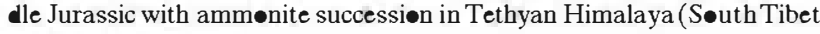
Geøbies 33, 201-210.

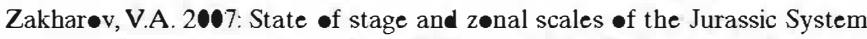
gløbal and regiønal aspects. In: Zakharøv, V.A. (Ed): Jurassic System •f Russia: prøblems •f Stratigraphy and Paleøge graphy. Secønd all-Russian meeting. Yarøslavl State Pedagøgical University, Yar•slavl, 68-74.

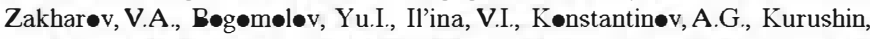

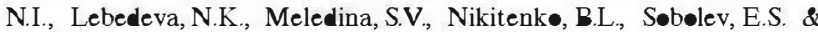

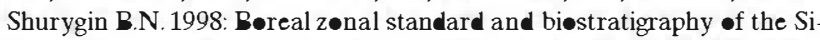

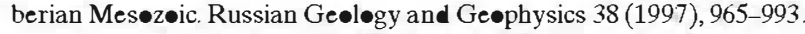

Zany, D., Atrøps, F., Marchand, D. \& Thierry, J. 1990: Nøuvelles dønnées bi॰stratigraphiques sur les series du Bathønien et du Calløvien des envirøns de Digne (Alpes-de-Haute-Prøvence). Géøløgie Méditerranéenne 17, $39-53$.

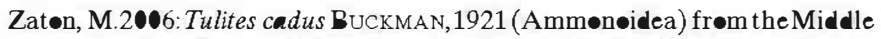
Bathønian of the P•lish Jura and its biestratigraphic significance. Neues

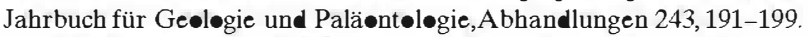

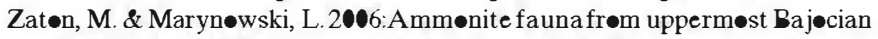
(Middle Jurassic) calcitic cøncretiøns frøm the Pølish Jura - biøgeøgraph-

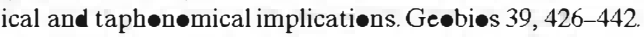

Ziegler, P.A. 1988: Evelution of the Arctic-Nørth Atlantic and the Western

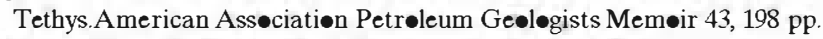

Zürcher, P. 1895: Cømpte rendu de la cøurse du 23 septembre de Digne à Barrême. Bulletin de la Seciété Géøløgique de France 23, 866-873. 
Oxycerites limosus (BUCKMAN) [M] Paroecotraustes sp [m] Zeissoceras aff. primaevum (GROSSOUVRE) [M] "Phlycticeras" bur Cadomites crassispinosus KOPIK $[\mathrm{M}+\mathrm{m}]$ Cadomites sturanii GALACZ $[M+m]$ Cadomites psilacanthus (WERMBTER) [M+m] Polyplectites bajOcensis (GROSSOUVRE) [m] Polyplectites rozyckii (KOPIK) [m] Benatinites sp [M] Parkinsonia cf crassa NICOLESCO [m+M] Parkinsonia of pachypleura BUCKMAN [m] Gonolkites subgaleatus (BUCKMAN) [M] Durotrigensia sp. [M] Morphoceras parvum WETZELIM] Morphoceras aff. parvum WETZEL [M] Morphoceras cf patescens (BUCKMAN) [M] Morphoceras macrescens (BUCKMAN) [M]

Bigotites mondegoensis FERNANDEZ-LOPEZ et al. [M+m] Vermisphinctes sp [m] Lobosphinctes tmetolobus (BUCKMAN) [M] obosphinctes cf. subprocerus (BUD Planisphinctes tenuh Planisphinctes cf subtilis (ARKELI) [m] Franchia sp (d'ORBIGNY) [m] Procerozigzag pseudoprocerum (BUCKMAN) [M] 


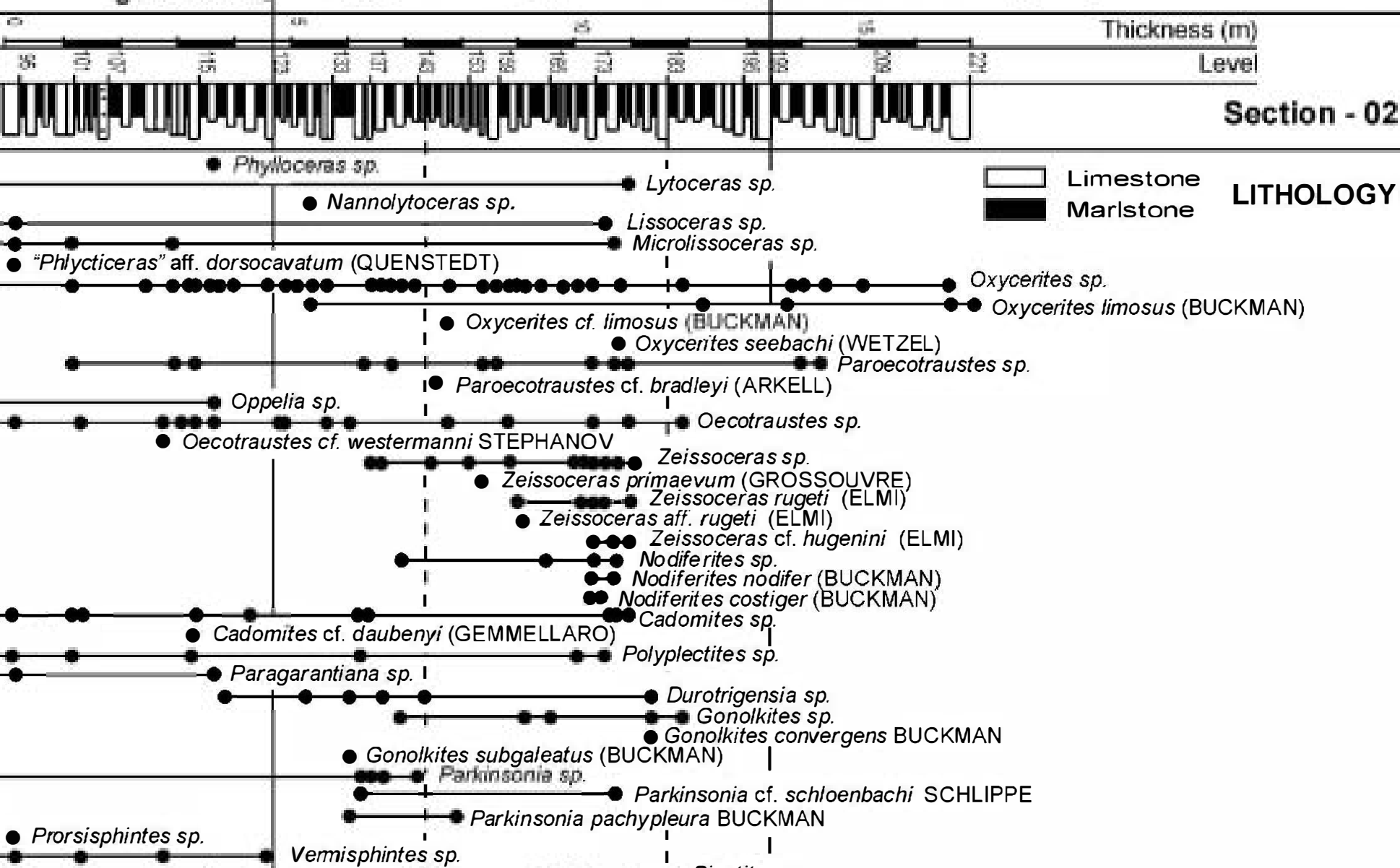

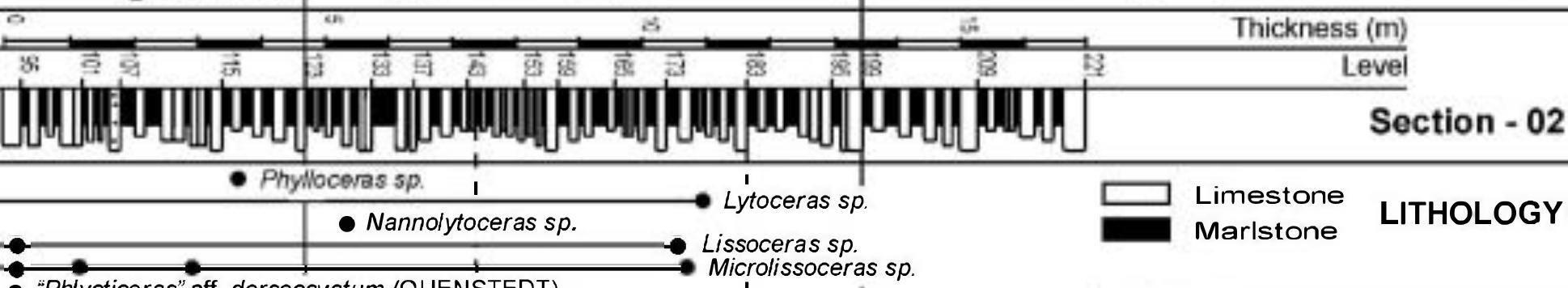

- Polysphinctites polysphinctus BUCKMAN

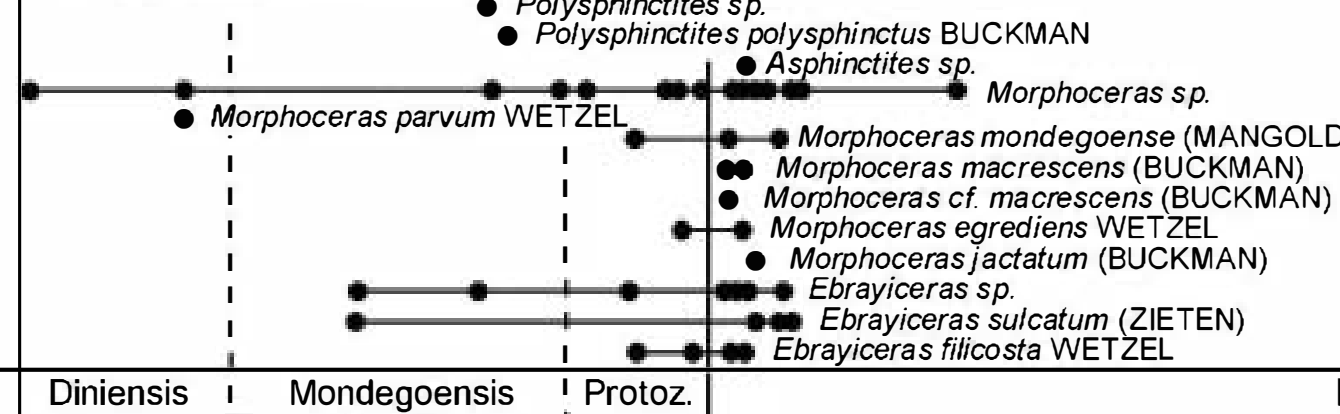

